\title{
Medicina narrativa: o significado de humanização para estudantes de Medicina
}

\author{
Dissertação apresentada à Faculdade de \\ Medicina da Universidade de São Paulo para \\ obtenção do título de Mestre em Ciências \\ Médicas
}

Programa de Ciências Médicas

Área de concentração: Educação Médica

Orientadora: Profa. Dra. Patricia Zen Tempski

\author{
SÃo PAULO
}

2017 
Dados Internacionais de Catalogação na Publicação (CIP)

Preparada pela Biblioteca da

Faculdade de Medicina da Universidade de São Paulo

Creprodução autorizada pelo autor

Tavares, Luciana de Almeida

Medicina narrativa: o significado de humanização para estudantes de medicina / Luciana de Almeida Tavares. -- São Paulo, 2017.

Dissertação(mestrado)--Faculdade de Medicina da Universidade de São Paulo.

Programa de Ciências Médicas. Área de concentração: Educação e Saúde.

Orientador: Patrícia Zen Tempski.

Descritores: 1.Humanização da assistência 2.Educação médica 3.Narração 4.Cultura

$\mathrm{USP} / \mathrm{FM} / \mathrm{DBD}-381 / 17$ 
Dedico este estudo à minha mãe, Suely (in memoriam), pela sabedoria, por não ter desistido nem ao menos por um segundo, por ter plantado a semente, cujo fruto é o presente texto.

Ao meu pai, Francisco, pelos exemplos de humanização de toda uma vida, e por todo apoio, incentivo e confiança.

Ao meu amor, que em sua humanidade, me estimula, me ensina, me eleva, me acolhe, me inspira todos os dias. 


\section{AGRADECIMENTOS}

Agradeço, de coração e eternamente...

Aos meus pais, Suely (in memorian) e Francisco, que me apresentaram a humanização desde sempre, em sua educação, em seu carinho, e em sua dedicação a mim e ao Fernando.

Ao meu irmão, Fernando, que bem sei que, em seu silêncio, sempre torceu e torce por $\operatorname{mim}$.

À minha orientadora, Patricia Tempski, não apenas pela sua orientação, mas também pelos inúmeros e valiosos aconselhamentos profissionais e pessoais.

Aos amigos e amigas, pela atenção que sempre me dedicaram quando eu quis ou precisei falar sobre o meu tema de pesquisa.

Ao meu príncipe, Régis, que chegou quando este vagão já estava em movimento, entrou, e se dispôs a meu ouvir, me ajudar e me orientar tantas vezes quantas precisei.

A Deus, porque sem as portas que abriu, e sem as oportunidades que me proporcionou, eu não teria chegado tão longe. 
Agir sem se entregar por inteiro à ação não é agir como homem, e nem o descanso do homem, nem sua instrução, nem sua formação podem disso resultar. Portanto, se os senhores já não contam com algumas, dessas que simplesmente se impõem, procurem causas que os apaixonem porque elas são de grande valia, obras de luz, de construção, de preservação, de progresso, ligas pelo bem público, associações de defesa e de ação social, empreendimentos todos que querem seu homem, se não quanto à vida dele em seu todo, pelo menos quanto a seu ser completo.

Antonin-Dalmace Sertillanges 


\section{NORMALIZAÇÃO ADOTADA}

Esta dissertação ou tese está de acordo com as seguintes normas, em vigor no momento desta publicação:

Referências: adaptado de International Committee of Medical Journals Editors (Vancouver).

Universidade de São Paulo. Faculdade de Medicina. Divisão de Biblioteca e Documentação. Guia de apresentação de dissertações, teses e monografias. Elaborado por Anneliese Carneiro da Cunha, Maria Julia de A. L. Freddi, Maria F. Crestana, Marinalva de Souza Aragão, Suely Campos Cardoso, Valéria Vilhena. 3a ed. São Paulo: Divisão de Biblioteca e Documentação; 2011. 


\section{SUMÁRIO}

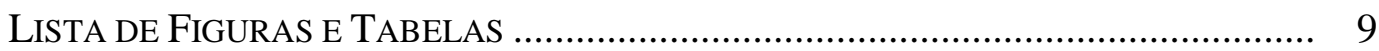

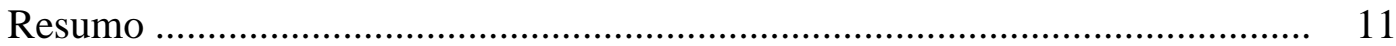

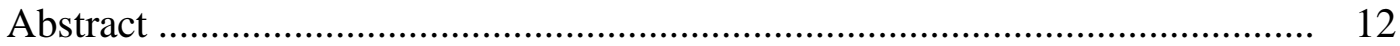

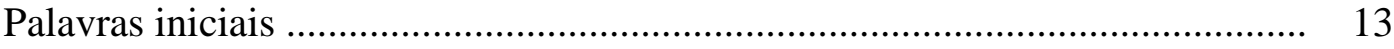

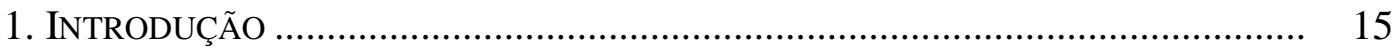

$1.1 \mathrm{O}$ estudante de Medicina e seu contexto ............................................... 15

1.2 Humanização do cuidado.................................................................... 16

1.3 Educação Médica: transdisciplinaridade e formação humanística do médico ....................................................................................... 21

1.4 Narrativa como manifestação de contextos pessoais e socioculturais ..... 26

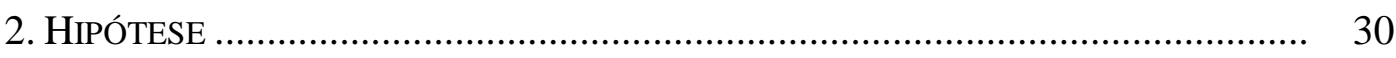

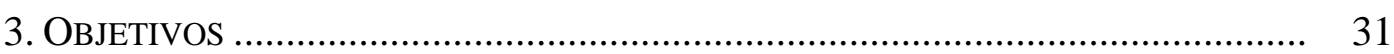

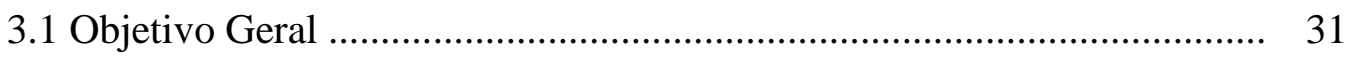

3.2 Objetivos Específicos ..................................................................... 31

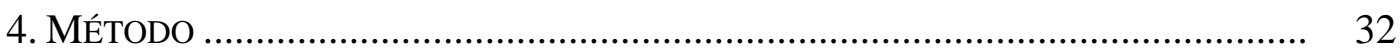

4.1 Caracterização do estudo .................................................................... 32

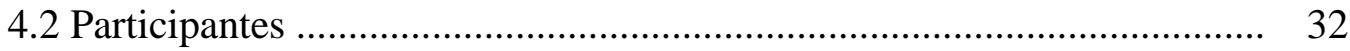

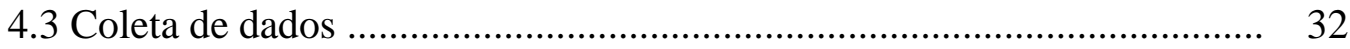

4.4 Análise de dados: da medicina narrativa à análise de conteúdo ............. 33

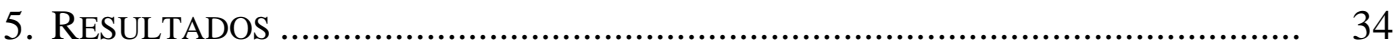

5.1 Caracterização da Amostra .................................................................. 34

5.2 Análise Qualitativa .......................................................................... 39

5.2.1 Análise das respostas à questão 1: Qual experiência ou motivos levaram você a escolher a profissão médica? 
5.2.2 Análise das respostas à questão 2: Humanizar é ... Complete com suas palavras

5.2.3 Análise das respostas à questão 3: Narre uma experiência de humanização ou desumanização vivida por você, utilizando quantas linhas forem necessárias

5.2.4 Análise das respostas à questão 4: Quando você pensa em humanização na prática médica, qual a imagem ou modelo vêm à mente? Comente histórias que você leu, ouviu, assistiu nos diferentes meios impressos, virtuais, sonoros (música), visuais (filmes, peças de teatro, séries, documentários)

7. DISCUSSÃO

7.1 Perfil e contexto dos estudantes respondentes

8. CONCLUSÕES

9. ANEXOS

10. REFERÊNCIAS 


\section{LISTA DE FIGURAS E TABELAS}

Figura 1: Perspectivas do estudo 16

Figura 2: Fluxograma das perdas do estudo

Figura 3: Representação gráfica da idade dos respondentes do estudo 35

Figura 4: Representação gráfica das religiões dos respondentes do estudo 35

Figura 5: Representação gráfica da naturalidade dos respondentes do estudo ..

Figura 6: Representação gráfica da natureza jurídica das instituições de ensino fundamental e médio frequentadas pelos respondentes do estudo .....

Figura 7: Representação gráfica da profissão dos pais dos respondentes do estudo

Figura 8: Representação gráfica da profissão das mães dos respondentes do estudo

Figura 9: Representação gráfica da renda familiar dos respondentes do estudo

Figura 10: Categorias de análise referentes à questão1: Qual experiência ou motivos levaram você a escolher a profissão médica?

Figura 11: Categorias de análise referentes à questão 2: Humanizar é ...

Complete com suas palavras.

Figura 12: Categorias de análise referentes à questão 3: Narre uma experiência de humanização ou desumanização vivida por você, utilizando quantas linhas forem necessárias.

Figura 13: Categorias de análise referentes à questão 4: Quando você pensa em humanização na prática médica, qual a imagem ou modelo vêm à mente? Comente histórias que você leu, ouviu, assistiu nos diferentes meios impressos, virtuais, sonoros (música), visuais (filmes, peças de teatro, séries, documentários).

Tabela 1: Análise qualitativa relativa à pergunta 1 Qual experiência ou motivos levaram você a escolher a profissão médica? Sua história é importante, utilize quantas linhas forem necessárias.

Tabela 2: Análise qualitativa relativa à pergunta 2

Humanizar é ... Complete com suas palavras. 
Tabela 3: Análise qualitativa relativa à pergunta 3

Narre uma experiência de humanização ou desumanização vivida por você, utilizando quantas linhas forem necessárias.

Tabela 4: Análise qualitativa relativa à pergunta 4

Quando você pensa em humanização na prática médica, qual a imagem ou modelo vêm à mente? Comente histórias que você leu, ouviu, assistiu nos diferentes meios impressos, virtuais, sonoros (música), visuais (filmes, peças de teatro, séries, documentários). .... 


\section{Resumo}

Tavares LA. Medicina narrativa: o significado de humanização para estudantes de medicina [Dissertação]. São Paulo: Faculdade de Medicina, Universidade de São Paulo; 2017.

A discussão a respeito do tema da humanização em saúde vem ganhando espaço nas sociedades ocidentais, desde a década de 1970 . No Brasil, com a promulgação do Programa Nacional de Humanização da Assistência Hospitalar e do HumanizaSUS, os debates se intensificaram. Conhecer o que pensam os estudantes de primeiro ano de medicina sobre o tema da humanização me motivou a questionar qual o sentido do termo para o estudante de primeiro ano de medicina da Faculdade de Medicina da Universidade de São Paulo. Os objetivos da pesquisa foram analisar o sentido de humanização para os estudantes ingressantes no curso de Medicina; investigar qual a relação entre valores e tendências dos alunos apresentados nas suas narrativas e aqueles propagados na sociedade contemporânea; examinar o conjunto de modelos familiares, sociais e midiáticos que permeiam o imaginário do estudante; e relacionar as experiências pessoais de humanização e ou desumanização como fontes da construção da própria narrativa. Os ingressantes responderam à pesquisa por meio de questionário sociodemográfico e por meio de narrativas, as quais foram analisadas a partir de estatística descritiva e pelo método da análise de conteúdo, respectivamente. O que permitiu traçar características singulares em relação aos participantes do estudo, e encontrar as seguintes categorias principais: o interesse pelo ser humano integral, o aspecto sociopolítico da medicina, a compreensão da singularidade e da diversidade humana, e os modelos que os influenciaram. As narrativas dos alunos demonstram a relação da humanização com a cultura, e reforçam o fato de estar o atendimento humanizado pautado na consideração e na compreensão da cultura dos pacientes. A análise do significado de humanização para os alunos de medicina revela que esse tema está relacionado, na percepção deles, a uma prática médica que envolva respeito, compreensão, solidariedade e visão integral do ser humano.

Descritores: Humanização da assistência; educação médica; narrativa; cultura. 


\begin{abstract}
Tavares LA. Narrative medicine: the meaning of humanization for medical students [Dissertation]. São Paulo: "Faculdade de Medicina, Universidade de São Paulo"; 2017.

The discussion regarding the humanization in health care services has been gaining more space in Western societies since the 1970's. In Brazil, with the promulgation of The National Program of Humanization and Hospital Care and HumanizaSUS, the discussions have intensified. To get to know what first grade medical students think about humanization have motivated me to question what is the meaning of this term for the medical students from Faculdade de Medicina da Universidade de São Paulo. The objectives of the research were to analyze the meaning of humanization for medical students that have just started medical college; to investigate the relation between moral values and trends of these students in their respective narratives and the ones that are spread out in the modern society; to examine the set of family structures, social and media conglomerates that permeate students imaginations and to relate their personal experiences with humanization and or dehumanization as a source of construction of their own narrative. The entering students have participated in the survey by responding to a sociodemographic and narratives questionnaire; and their responses were analyzed through descriptive statistics and content analysis methods, respectively. It allowed us to map single characteristics among the participants and to identify the following main categories: the interest by the integral human, the socio-political aspect of the medicine, the understanding of human singularity and diversity and the factors that have influenced them. The students narratives show the relation of humanization with culture and reinforce the fact that humanized health care is based in the consideration and comprehension of patients' culture. The analyses of the meaning of humanization for medical students reveal that this topic, according to their perception, is related to a clinical practice that involves respect, comprehension, sympathy and a global view of the human being.
\end{abstract}

Descriptors: Humanization of assistance; medical education; narration; culture. 


\section{Palavras Iniciais}

A tua história é o bem mais precioso que tens, ainda que não venha a ser grandiosa, é a tua história que te dará a medida de estar no mundo, ela é que exorbita ou reduz o teu valor perante ti mesma e perante a misteriosa avaliação dos outros ... qualquer história, enquanto se desdobra, é um reino de possibilidades.

João Anzanello Carrascoza

Sou Luciana Tavares e aqui apresento um pouco da minha história. Sou formada em Ciências Sociais pela PUC-SP, curso que finalizei em 1997. Posteriormente, algumas experiências pessoais com processos de adoecimento estimularam meu interesse por questões relativas à área da saúde, mais especificamente, à relação estabelecida entre profissionais da saúde e seus pacientes.

Minhas buscas por cursos de especialização ou pós-graduação me conduziram ao tema da Humanização em Saúde. O fato de esta temática tratar de posicionamentos, atitudes e visões de mundo das pessoas envolvidas, e de estar relacionada com aspectos sociais e culturais me chamou a atenção, uma vez que eu poderia, dentro da área da saúde, trabalhar assuntos relacionados à minha formação, no campo das ciências humanas. Comecei a perceber também a importância de trabalhar na direção da Humanização com os profissionais da saúde desde os anos de sua formação.

Conheci, então, a Medicina Narrativa, e nela pude perceber um caminho interessante para unir os dois campos de conhecimento: Medicina e Ciências Humanas.

A motivação maior deste estudo veio da crença de que tanto as nossas decisões, percepções e visões de mundo, como os rumos que a nossa vida toma são influenciados pelos ambientes familiar e sociocultural que nos envolve e com os quais interagimos desde a infância. Daí o propósito de analisar as motivações dos estudantes e sua compreensão a respeito do tema da Humanização no contexto social, inseridas no curso de Medicina, por meio das suas narrativas.

As narrativas são expressões variadas da realidade percebida pelas pessoas, que nos permitem analisar os aspectos envolvidos em seus pensamentos, no caso deste 
estudo, a visão dos estudantes sobre humanização, motivação para escolher a carreira médica e seus modelos. 


\section{INTRODUÇÃo}

\subsection{O estudante de Medicina e seu contexto}

... cada ser tem uma multiplicidade de identidades, uma multiplicidade de personalidades em si mesmo, um mundo de fantasias e de sonhos que acompanham sua vida. [...] não é só a sociedade que é complexa, mas cada átomo do mundo humano.

Edgar Morin

O estudante ingressante no curso de Medicina traz consigo para este novo ambiente educacional valores, perspectivas e visões de mundo construídos a partir das relações sociais que viveu até então. Tais relações são associadas às suas interações com a família, a sociedade e a cultura contemporânea, e pautam os significados das vivências, dos pensamentos e dos ideais para este jovem.

Ao buscar compreender o significado de humanização para o estudante de Medicina por meio de suas narrativas, deparamo-nos com um conjunto de valores e visões de mundo expresso em seus textos, em suas histórias, em suas experiências vividas. A partir destas expressões pessoais, podemos traçar paralelos, convergências ou divergências entre os valores e posicionamentos dos estudantes e as características da sociedade contemporânea.

O ambiente de ensino da Faculdade de Medicina da Universidade de São Paulo também está inserido neste contexto sociocultural contemporâneo, que chamaremos aqui de modernidade, com todos os seus conflitos, propostas, paradigmas, angústias, expectativas, promessas e incertezas (Berman, 2007; Lévi-Strauss, 2012; Morin e Kern, 2011). Portanto, entender o significado de humanização para o estudante de Medicina implica também compreender a sociedade e a cultura em que ele vive. As perspectivas adotadas neste estudo estão representadas na Figura 1. 


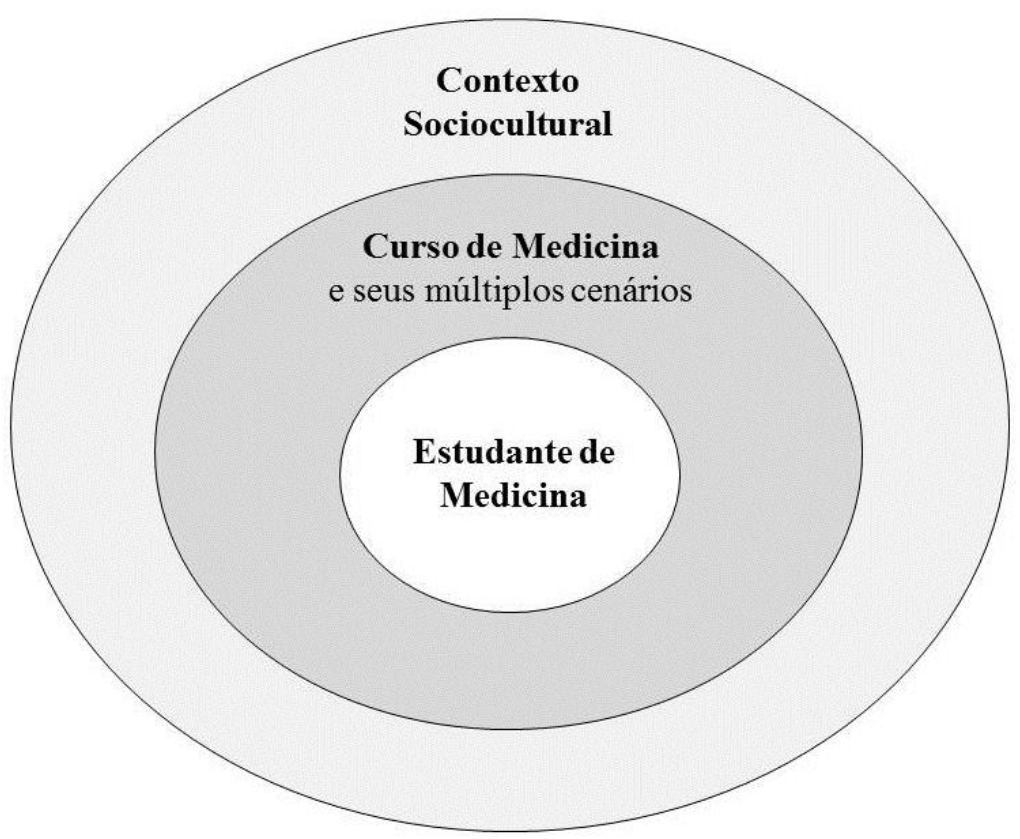

Figura 1: Perspectivas do estudo

A ideia de buscar compreender o perfil deste jovem e o que ele pensa a respeito de humanização, no seu ingresso no curso de Medicina, oferece a oportunidade de analisar diversas questões a partir das suas narrativas, como se pode observar: o ambiente sociocultural no qual este estudante está inserido; as influências sociais, culturais ou familiares envolvidas em suas escolhas e em seus posicionamentos; as características da sociedade contemporânea que podem ser identificadas nestes jovens; os modelos que influenciam suas escolhas; as contradições em relação à sociedade contemporânea expressas nas narrativas; as experiências pessoais significativas e orientadoras de suas ideias; as expectativas que os estudantes depositam em seu futuro; as tendências deste grupo de alunos expressas em relação à prática médica; os pensamentos divergentes do senso comum que emergem das narrativas; e, sobretudo, o significado de humanização para este grupo de estudantes.

\subsection{Humanização do cuidado}

A humanidade começa nos que te rodeiam, e não exatamente em ti. 
Dezesseis anos após a instituição do Programa Nacional de Humanização da Assistência Hospitalar (PNHAH-MS, 2001), o debate sobre humanização no atendimento em saúde permanece vivo e necessário. Antes da promulgação deste programa, o assunto vinha sendo tratado com o intuito de apontar para necessidades encontradas no âmbito do atendimento em saúde, e com o propósito de definir o conceito de humanização em saúde. O conceito de humanização é objeto de trabalho e pesquisa de profissionais de diversas áreas, e compõe materiais e conteúdos de estudo de médicos, psicólogos e cientistas sociais.

$\mathrm{Na}$ literatura, o termo humanização aborda, principalmente, comportamentos humanizados/desumanizados por parte de profissionais da saúde. Para o presente estudo, uma noção de humanização ampla e abrangente será adotada, levando a discussão para além da esfera das atitudes, alcançando a esfera do ser, sem desprezar, é claro, o necessário treinamento oferecido nas escolas médicas a respeito da comunicação entre médico e paciente. Trabalharemos com a potencialidade do termo humanização, que reporta a um relacionamento entre pessoas em sua integridade, que diz respeito a posicionamentos éticos e morais, políticos e sociais, os quais tendem a direcionar e das as bases para os comportamentos humanos.

Ao analisar alguns dos problemas presentes nas relações entre médico e paciente - desatenção, falta de acolhimento, pouco tempo para escuta, pouco interesse pela história da doença e do próprio paciente, descaso com a vida do paciente e com a relação com os familiares, falta de empatia, frieza, prescrição de medicamentos ou tratamentos inadequados, entre outros -, percebe-se que em muitas situações as necessidades de saúde do paciente têm sido atendidas de forma insuficiente.

Gallian e Reginato (apud Bittar, Sousa e Gallian, 2013) apontam para o problema de se focar a discussão sobre humanização apenas em comportamentos e atitudes. Observam que os "treinamentos" realizados até o momento para "desenvolver habilidades humanísticas" nos estudantes e nos profissionais de saúde têm sido ineficientes. Porque humanizar não se trata apenas de realizar mudança, aprimoramento ou adequação de comportamentos. Humanizar diz respeito a algo que precede as atitudes. Está relacionado a um âmbito filosófico e cultural. Enquanto a perspectiva de mundo, de vida e de existência humana continuarem pautadas no tecnicismo, no 
pensamento fragmentário, nas ideias de superespecialização e no individualismo, a humanização continuará destituída do espaço necessário para ser elaborada e desenvolvida, fortalecida e conservada nas relações entre profissionais da saúde e seus pacientes.

Com relação aos conceitos mais comumente usados pelos profissionais e pesquisadores do campo da saúde, Ayres (2005) aponta que diversos sentidos foram dados para a humanização:

... oposição à violência institucional; qualidade do atendimento, associando excelência técnica com capacidade de acolhimento e resposta; cuidado com as condições de trabalho dos profissionais; ampliação da capacidade de comunicação entre usuários e serviços. (Ayres, 2005)

Num olhar retrospectivo, a socióloga, professora e pesquisadora Suely Ferreira Deslandes (2006) aponta que, mesmo sendo o humanismo tema recorrente desde a Antiguidade, hoje ele se constitui "como política, como proposta, como debate, como tema de pesquisa por meio do vocábulo ‘humanização"” (Deslandes, 2006, p. 26).

Pensar sobre humanização expande as fronteiras e os limites das práticas de saúde, segundo os quais o médico e o paciente não somente trocam breves e objetivas informações sobre a doença, mas, também, passam a olhar para a sua relação como um encontro entre duas subjetividades, duas histórias de vida, dois seres portadores de sonhos e desejos de alcançar uma vida melhor, uma vida boa em todos os aspectos.

Ayres (2005) aponta a importância:

de entendermos a humanização em sua inexorável politicidade e socialidade e, por conseguinte, em suas importantes implicações institucionais. Neste sentido, a problemática da humanização [...] trata-se de um projeto existencial de caráter político, trata-se de uma proposta para a 'polis'.

A partir deste pensamento, entendemos a necessidade de se compreender que pessoas, sociedade e política interagem, dialogam e se retroalimentam na construção do comportamento ético e da visão de mundo das pessoas envolvidas nas relações no campo da saúde. 
Neste sentido, Ayres $(2004 ; 2005)$ procura apresentar o caráter social e político do atendimento humanizado à saúde. Esta perspectiva corrobora com a do professor de Medicina Interna e Educação Médica na Universidade de Michigan, Arno Kumagai (2014), segundo a qual há um aspecto social na profissão do médico. Tal aspecto deve ser levado em consideração para que a relação médico-paciente seja efetivamente humanizada, vinculando a humanização ao compromisso com a felicidade humana, e, também, com uma proposta política. Neste ponto, Ayres (2004) salienta que:

... embora se aceite que a felicidade humana é, em essência, uma experiência de caráter singular e pessoal, a referência à validação democrática de valores que possam ser publicamente aceitos como propiciadores dessa experiência é do que parece tratar-se quando se discute a humanização da atenção à saúde como uma proposta política, envolvendo inclusive as instituições do Estado.

A fim de abordar tais aspectos, Deslandes (2004) escreveu um artigo referenciado na bibliografia a respeito de humanização, no qual analisou "o discurso oficial sobre humanização da assistência hospitalar". Neste artigo, ao refletir sobre o Programa Nacional de Humanização da Assistência Hospitalar, a autora observa que antigas demandas da saúde são recuperadas com a discussão sobre humanização, como: a democratização das relações que envolvem o atendimento; maior diálogo e melhoria da comunicação entre profissional de saúde e paciente e reconhecimento das expectativas dos próprios profissionais e as dos pacientes, como pessoas atuantes no processo terapêutico (Deslandes, 2004).

O documento oficial do Ministério da Saúde aponta como significados de humanização: a humanização como oposição à violência; a humanização como ampliação do diálogo e da comunicação entre profissionais de saúde e paciente, e entre os próprios profissionais da saúde; a humanização como atendimento de qualidade unindo técnica ao bom relacionamento; humanização como melhoria das condições de trabalho do cuidador. Segundo Deslandes, um investimento sério na formação dos profissionais de saúde deve ser feito para que se alcance o devido sucesso nesta nova cultura da assistência proposta pelo PNHAH (MS, 2001). 
Ao discorrer a respeito da humanização na Medicina e na Educação Médica, Rios e Schraiber (2012) discutem o tema por meio da sua contextualização social e histórica. "A humanização surge, na história mais recente da saúde no país, sob a forma de movimentos políticos e ideológicos para a transformação da cultura e da prática profissional em uma perspectiva interativa" (Rios e Schraiber, 2012, p. 16). As autoras observam que a dificuldade de "humanizar" não está apenas na Medicina, mas na própria configuração social contemporânea. Portanto, discutir humanização implica em discutir como estão se configurando as relações sociais contemporâneas.

$\mathrm{Na}$ sociedade onde o esmaecimento dos valores humanísticos e a violência no comportamento e nas relações entre as pessoas são presenças cotidianas, a reflexão sobre temas das ciências humanas, no âmbito da medicina, é condição imprescindível para a passagem de estudante a médico. A conduta moral e a competência ética são resultados do desenvolvimento da capacidade dos indivíduos para a busca do bem individual e coletivo, busca que também considera a perspectiva dos outros e não elege a si mesmo como única referência para a compreensão do mundo. (Rios et al., 2008)

Deduz-se daí que seja possível treinar alguém para tocar, para olhar nos olhos, para sorrir, para ser educado, e até mesmo para ser amável. Mas que, entretanto, tais atitudes serão débeis e instáveis se não derivarem de um juízo construído internamente, se não partirem de uma consciência ética e moral com relação ao melhor a ser feito. Se não emergirem de uma esfera mais profunda do ser, que envolve a ética e a moral, tais comportamentos ruirão diante de uma situação turbulenta, conflitante, adversa; e o distanciamento entre o simples fazer a que foi treinado e quem se é verdadeiramente levará a pessoa a atuar, ainda, sob o domínio da desumanização.

É dentro dessa conjuntura que compreendemos a humanização. É na fusão dos horizontes $^{1}$ de um serviço prestado e seus usuários, de um profissional de saúde e seu paciente, que se dá o diálogo e a troca de linguagens que proporcionarão o

\footnotetext{
${ }^{1}$ O filósofo alemão Hans-Georg Gadamer define, em seu livro Verdade e Método (p. 333 e 404): "Horizonte é o âmbito de visão que abarca e encerra tudo o que pode ser visto a partir de um determinado ponto. Aplicando esse conceito à consciência pensante, falamos então da estreiteza do horizonte, da possibilidade de ampliar o horizonte, da abertura de novos horizontes etc." E afirma: "O horizonte do presente não se forma pois à margem do passado. Não existe um horizonte do presente por si mesmo, assim como não existem horizontes históricos a serem conquistados. Antes, compreender é sempre o processo de fusão desses horizontes presumivelmente dados por si mesmos."
} 
entendimento mútuo e o caminhar na direção dos projetos existenciais de cada pessoa envolvida no processo.

\subsection{Educação Médica: transdisciplinaridade e formação humanística do médico}

No seu núcleo, a medicina é uma ciência humana.

Arno Kumagai

Fundamentado em pesquisas e evidências científicas, biomédicas e tecnológicas, o saber médico vem sendo construído pelo diálogo com as ciências humanas (sociologia, antropologia, ciência política, história, psicologia social) e as humanidades (literatura, cinema, artes plásticas e visuais). Tal interação tem sido expressa de forma crescente nas pesquisas científicas, em produções acadêmicas, e no contexto da Educação Médica (Kumagai, 2008, 2009, 2013, 2014; Shapiro et al., 2009; Canesqui, 2010; Kloster et al., 2013; Minayo, 2013; Nunes, 2014; Cockerham, 2014).

Kumagai (2014) entende que "a Medicina é um tipo de humanismo aplicado, isto é, a aplicação da ciência no reconhecimento de valores humanos e ao serviço das necessidades humanas". Neste sentido, observa-se a importância de motivar os médicos, desde a formação, a compreenderem os contextos pessoais e socioculturais nos quais seus pacientes estão envolvidos. Tal entendimento poderá transformar significativamente sua prática clínica e desenvolver os relacionamentos com seus pacientes de forma que o atendimento alcance os níveis de qualidade esperados por ambos. O atendimento humanizado proporciona ao médico uma maior adesão do paciente às suas orientações de tratamento, bem como traz ao paciente plena satisfação (e, por que não dizer, o alívio para as angústias e fragilidades trazidas pela doença).

Segundo Minayo (2013), as transformações sociais, políticas, econômicas e culturais pelas quais passa o mundo desde fins do século $\mathrm{XX}$ levaram à diluição das fronteiras - não só geográficas, mas também comunicativas e disciplinares. Começaram a ganhar espaço, então, discussões, pesquisas e estudos transdisciplinares, mesmo que, institucionalmente, os saberes ainda continuem fortemente organizados em disciplinas. 
Todos os saberes e as práticas envolvidos no campo da saúde são compostos pelas inúmeras dimensões da existência humana. Tanto o campo da saúde quanto o das ciências humanas lidam com a existência humana, o que constitui, portanto, a evidência de que ambos os campos de saber estão inexoravelmente relacionados.

Ao compreender a importância desta conexão, Kumagai e Lypson (2009) apontam a necessidade de colocar a Medicina num contexto social, cultural e histórico de modo a possibilitar que o estudante de Medicina reconheça os problemas sociais e seja capaz de pensar soluções apropriadas, no que se refere à sua prática médica (agora devidamente contextualizada). Em última instância, os autores abordam o tema da justiça social: é o que ocorre quando o atendimento de alta qualidade do médico se dirige aos membros da sociedade independente de sexo, raça, etnia, religião, linguagem, origem geográfica ou condição socioeconômica.

Desta forma, humanizar a Medicina depende do reconhecimento do médico e do estudante de Medicina, de que seu profissionalismo está relacionado a "um profundo e permanente engajamento pessoal com a Medicina como atividade social e moral" (Kumagai, 2014).

A prática médica deve estar conectada às necessidades sociais. Para tanto, faz-se necessário que o estudante passe pela educação interdisciplinar - na qual os estudos das disciplinas médicas estejam conectadas com os estudos culturais, sociais, políticos, éticos, humanísticos. Oferece-se, então, uma maior oportunidade para que as ações deste médico sejam dirigidas às necessidades de saúde, bem como comprometidas com a sociedade. Se um dos atributos da humanização é o comprometimento, consigo mesmo, com o outro, com a profissão, com o mundo e com a sociedade, este compromisso e engajamento com a realidade e com a própria existência humana é o propulsor da humanização do homem, e precisa ser trabalhado nos anos de formação do profissional. Neste sentido, o professor e educador Fernandes (2017, p. 71) aponta:

... a educação clássica é a pedagogia do oprimido pela ignorância que busca a autonomia para que, por suas próprias pernas, possa buscar o que é bom, belo e verdadeiro; possa trabalhar, contemplar a realidade e ter cada vez mais certeza de que está no caminho certo, caminho sem fim, mas certo. 
O educador norte-americano Mortimer J. Adler (1902-2001) ofereceu a reflexão a respeito de uma educação que tenha como foco o desenvolvimento humano, que prepara os indivíduos para exercer sua cidadania: "Os estudantes devem ser preparados e motivados para fazer de si mesmos os melhores seres humanos em que forem capazes de se transformar", Adler (1984, p. 32).

Atuar na formação do médico é um instrumento poderoso de transformação de sua prática profissional (Caprara e Franco, 1999). Neste aspecto, como qualquer outro profissional, o profissional da saúde tem uma forte influência da sua formação universitária. Os professores, tutores, residentes e colegas que fazem parte de sua trajetória acadêmica o ajudam a traçar seus objetivos, sua forma de pensar e de agir.

No contexto da formação crítica e dos modelos apresentados aos estudantes, insere-se a discussão sobre a formação humanística do médico. Direta ou indiretamente, os educadores têm um papel fundamental na formação da visão do aluno em seu processo de vir a ser médico.

Os estudos apresentados por Lima et al. (2014) e Kumagai (2010) comprovam que a atitude de reflexão - sobre si mesmos, suas experiências, sobre os pacientes ou sobre as práticas médicas - a partir do estudo das humanidades leva médicos e profissionais da saúde a se aprimorarem como seres humanos e, consequentemente, a repensar, adequar, aperfeiçoar suas práticas e enriquecer seus relacionamentos sociais, profissionais e pessoais.

O aluno de Medicina, por meio do estudo das ciências humanas (temas ligados à sociologia, política, antropologia, história) e das humanidades (temas ligados às artes, à literatura, à cultura), encontra a oportunidade para refletir sobre seus próprios valores, princípios, seus posicionamentos diante da sociedade, suas influências culturais, seus pensamentos e ideais. Tal reflexão possibilitará ao aluno construir uma consciência crítica sobre si mesmo, sobre sua profissão e sobre a sociedade, visto que o entendimento do ser humano e do seu próprio papel como médico se tornará mais amplo e mais profundo. O contato com a formação humanística pode, de diversas maneiras, auxiliar o médico a lidar com aspectos existenciais do paciente, que, inevitavelmente serão trazidos para sua prática clínica, lembrando que: "formar um médico é preparar alguém para exercer uma atividade complexa, fundamental para a vida e as realizações da espécie humana e de cada homem" (Pessotti, 1996). Ainda neste 
sentido, e a respeito da formação interdisciplinar para o estudante de medicina e sobre a preparação integral do ser humano, nas quais se possa tecer junto o conjunto de competências e habilidades humanas e profissionais, vale destacar:

A despeito da ausência de uma ciência do homem que coordene e ligue as ciências do homem (ou antes, a despeito da ignorância dos trabalhos realizados neste sentido), o ensino pode tentar, eficientemente, promover a convergência das ciências naturais, das ciências humanas, da cultura das humanidades e da Filosofia para a condição humana. Seria possível, daí em diante, chegar a uma tomada de consciência da coletividade do destino próprio da nossa era planetária, onde todos os humanos são confrontados com os mesmos problemas vitais e mortais. [...] É preciso substituir um pensamento disjuntivo e redutor por um pensamento do complexo, no sentido originário do termo complexus: o que é tecido junto. (Morin, 2010, p. 46 e 89)

A ideia da humanização como prática pedagógica está contida nas Diretrizes Curriculares Nacionais e internacionais quando elas definem, como uma competência, a compreensão do paciente como um ser biopsicossocial (DCN - Brasil, 2014; CanMeds, 2016; WFME, 2016). E ainda, as mesmas diretrizes apontam que a educação médica deve contemplar a "compreensão dos determinantes sociais, culturais, comportamentais, psicológicos, ecológicos, éticos e legais, nos níveis individual e coletivo, do processo saúde-doença".

Neste sentido, citamos as DCN brasileiras de 2001, bem como as DCN de 2014, que propõem, no seu Art. $3^{\circ}$ :

O Curso de Graduação em Medicina tem como perfil do formando egresso/profissional o médico, com formação generalista, humanista, crítica e reflexiva, capacitado a atuar, pautado em princípios éticos, no processo de saúde-doença em seus diferentes níveis de atenção, com ações de promoção, prevenção, recuperação e reabilitação à saúde, na perspectiva da integralidade da assistência, com senso de responsabilidade social e compromisso com a cidadania, como promotor da saúde integral do ser humano.

Além desta resolução, destacamos da DCN algumas competências que, para serem alcançadas, necessariamente passam por uma aquisição de conhecimento transdisciplinar. São elas: 
I - promover estilos de vida saudáveis, conciliando necessidades tanto dos seus clientes/pacientes quanto às de sua comunidade, atuando como agente de transformação social;

$[\ldots]$

VI - dominar os conhecimentos científicos básicos da natureza biopsicosocio-ambiental subjacentes à prática médica e ter raciocínio crítico na interpretação dos dados, na identificação da natureza dos problemas da prática médica e na sua resolução;

$[\ldots]$

XII - reconhecer a saúde como direito e atuar de forma a garantir a integralidade da assistência entendida como conjunto articulado e contínuo de ações e serviços preventivos e curativos, individuais e coletivos, exigidos para cada caso em todos os níveis de complexidade do sistema;

$[\ldots]$

$\mathrm{XX}$ - ter visão do papel social do médico e disposição para atuar em atividades de política e de planejamento em saúde; (Grifos nossos)

O sistema de competências médicas da "Royal College", no Canadá, o CanMEDS $^{2}$, também define de forma transdisciplinar a expertise médica, estabelecendo como metas educacionais os papéis que devem ser assumidos pelos médicos.

Por exemplo, em relação ao papel Comunicator, CanMADS propõe que o conhecimento do médico deve integrar a situação socioeconômica, a história médica, a história familiar, o estágio da vida, a situação de vida e outras questões sociais e psicológicas do paciente. Isso implica em conhecer os valores e preferências do paciente e a adequação do diagnóstico e tratamento a estas particularidades. Requer também uma formação integral e humanística do médico, para que este seja capaz de uma avaliação e compreensão mais ampla do paciente, da sua doença e de seus contextos.

Já no documento "Tomorrow's Doctors", publicado pelo "General Medical Concil", 3 a formação ampla e humanística do médico também é abordada. Alguns objetivos da graduação em Medicina propõem que o médico:

Aplicar princípios, método e conhecimento psicológicos para a prática médica. Aplicar os princípios, o método e o conhecimento das

\footnotetext{
${ }^{2}$ Disponível em http://www.royalcollege.ca/rcsite/canmeds/about-canmeds-e. Acessado em 21/05/2016.

${ }^{3}$ Disponível em http://www.gmc-uk.org/education/undergraduate/undergrad_outcomes.asp. Acessado em 21/05/2016.
} 
ciências sociais para a prática médica. Tomar e registrar o histórico médico de um paciente, incluindo história familiar e social, falando com familiares ou outros cuidadores quando apropriado. Interpretar os resultados da história, exame físico e exame mental-estado, apreciando a importância dos fatores clínicos, psicológicos, espirituais, religiosos, sociais e culturais. Comunicar-se de forma clara, sensível e eficaz com indivíduos e grupos, independentemente da idade, das origens sociais, culturais ou étnicas ou das suas deficiências, inclusive quando o inglês não é a primeira língua do paciente.

Para que um médico atue numa esfera mais ampla do que aquela oferecida pelo instrumental biológico e físico, portanto, a partir do que vimos até o momento, e do conteúdo das próprias diretrizes nacionais e internacionais para a educação médica, é preciso oferecer ao estudante uma formação que lhe permita perceber mais atenta e profundamente o seu semelhante, bem como a cultura, a sociedade e todo o ambiente que o rodeia. Assim, é estimulada no estudante a capacidade de analisar as singularidades e as pluralidades das experiências clínicas através de uma compreensão humanística do atendimento em saúde. A formação humanística e transdisciplinar, neste contexto, agrega outro tipo de conhecimento ao conhecimento biomédico e às experiências clínicas vividas pelo estudante na faculdade. É o conhecimento da condição humana, condição esta que precede a própria dor e a doença, mas que conduzirá os caminhos para lidar com a dor, com o sofrimento e com a doença.

\subsection{Narrativa como manifestação de contextos individuais e socioculturais}

A narrativa não se esgota jamais. Ela conserva suas forças e depois de muito tempo ainda é capaz de desdobramentos.

Walter Benjamin

Psicanalítica, ideológica e socialmente, entende-se que as palavras não são usadas aleatoriamente - par hasard, como mencionam Henry e Moscovici (1968). "O narrador retira o que ele conta da experiência: de sua própria experiência ou da relatada por outros. E incorpora, por sua vez, as coisas narradas à experiência dos seus ouvintes" (Benjamin, 2012, p. 217). 
As palavras exprimem determinado pensamento, ideia, comportamento ou tendência, proporcionando ao pesquisador e analista das narrativas a oportunidade de compreender e interpretar os significados das palavras, quando estudadas em seu contexto.

Optamos por realizar a pesquisa coletando narrativas porque entendemos, como Charon (2001), que há dimensões narrativas na Medicina. Além disso, a partir do contato com uma variedade de estudos que utilizaram narrativas com estudantes de Medicina $^{4}$, e da leitura de outros textos sobre aspectos da narrativa, podemos depreender que a narrativa carrega em si o potencial de expressar valores, posicionamentos, sentimentos e tendências socioculturais de seus autores. (Squire, 2014; Brockmeier e Harré, 2003).

"A narrativa é uma cadeia de signos com sentidos sociais, culturais e históricos" (Squire, 2014). Cabe, portanto, ao pesquisador analisar os contextos em que as diferentes ou semelhantes vozes se expressam.

As narrativas se apresentam como um método reconhecido de compreender significados de ações, pensamentos, eventos ou instituições, pois consistem no registro linguístico de histórias e experiências, ou, outras vezes, de ficções, que, inseridas em um contexto histórico, social e cultural, fornecem um panorama da realidade daquelas pessoas e de seus papeis sociais.

Adotamos para este estudo a definição de narrativa de Brockmeier e Harré (2003):

Em seu sentido mais corrente e geral, a narrativa é o nome para um conjunto de estruturas linguísticas e psicológicas transmitidas cultural e historicamente, delimitadas pelo nível do domínio de cada indivíduo e pela combinação de técnicas sociocomunicativas e habilidades linguísticas [...] e, de forma não menos importante, por características pessoais como curiosidade, paixão e, por vezes, obsessão. Ao comunicar algo sobre um evento da vida - uma situação complicada, uma intenção, um sonho, uma doença, um estado de angústia - a comunicação geralmente assume a forma da narrativa, ou seja, apresenta-se uma estória contada de acordo com certas convenções.

\footnotetext{
${ }^{4}$ Arntfield et al., 2013; Bernard et al., 2011; Campos e Furtado, 2008; Castellanos, 2014; Charon, 2001; DasGupta e Charon, 2004; De Benedetto, 2010; De Benedetto, Blasco e Gallian (s/d); Dyrbye, Harris e Rohren, 2007; Garrison et al., 2011; Grossman e Cardoso, 2006; Favoreto e Camargo Jr., 2011; Favoreto e Cabral, 2009; Hurwitz, 2000; Johna, Woodward e Patel, 2014; Karnieli-Miller et al., 2010; Levine, Kern e Wright, 2008; Medeiros et al., 2013; Monrouxe, Rees e Ternan, 2014; Puvanendan et al., 2012; Rees, Monrouxe e McDonald, 2013; Shapiro, Kasman e Shafer, 2006; Urquhart, Rees e Ker, 2014; Wong e Trollope-Kumar, 2014.
} 
Já a Medicina Narrativa tem por definição ser a Medicina praticada com habilidades narrativas de reconhecer/identificar, absorver, interpretar e ser movido pelas histórias de doença e para agir em direção ao outro. Criada na década de 1990 pela médica Rita Charon, da Columbia University, e pelo médico Brian Hurwitz, do King's College London, a Medicina Narrativa visa estimular a sensibilidade dos médicos (alunos de Medicina, médicos, profissionais de saúde em geral) a fim de que pratiquem a assistência centrada no paciente, a partir do autoconhecimento, da reflexão sobre suas práticas e do ato de ouvir atentamente as histórias de doenças de seus pacientes. Rita Charon explica que o ato de narrar (escrever ou falar) reflexivamente demanda que o médico ouça e compreenda o paciente para além do atendimento médico ou da aplicação de exames e novas tecnologias ao tratamento (Shannon et al., 2013; Charon, 2001; Charon, 2005).

As principais características da Medicina Narrativa são o estudo de narrativas relacionadas a doenças, à relação médico-paciente, à relação profissional entre médicos e a aspectos da formação médica, e ao incentivo à prática narrativa com o objetivo de humanizar as relações no campo da saúde por meio da sensibilização das pessoas que estão produzindo as narrativas.

Construída a partir do estudo da Medicina centrada no paciente, e unida ao estudo de literatura, de crítica literária e das narrativas, a Medicina Narrativa carrega em si o potencial de nos trazer dimensões importantes a respeito dos pensamentos e posicionamentos dos estudantes de Medicina no decorrer dos anos de formação. Diversos aspectos do pensamento do estudante no que se refere ao tema da humanização poderão ser observados a partir de suas satisfações, alegrias e recompensas, mas também a partir das vicissitudes, dificuldades e frustrações encontradas no mundo da Medicina.

Justamente em contraposição aos aspectos desestruturantes e desumanizados presentes em nossa sociedade e que têm afligido os relacionamentos sociais, a Medicina Narrativa vem para restaurar, recompor, recuperar, edificar, oferecer alívio e um respiro às relações humanas, propondo o ouvir, o doar-se, o compadecer-se e o comprometer-se com o outro. Ela propõe que, ao considerar os diferentes elementos que compõem um relacionamento - o humor, os silêncios, as mudanças corporais, a falta de palavras, 
unidos à linguagem e à história narrada - o médico passe a conhecer efetivamente o seu paciente (Charon, 2012B).

Assim, as narrativas dos próprios estudantes, proporcionaram, por um lado, que os alunos que compuseram este estudo pudessem refletir sobre sua futura prática médica, já no primeiro ano de formação; por outro lado, ofereceram a oportunidade de observarmos quais são os aspectos predominantes em suas escolhas, em seus ideais e em sua prática médica, uma vez que, como não há como escrever de forma neutra, as narrativas médicas expressam visões de mundo e a cultura na qual se está imerso (Charon, 2012A; 2012B).

Tida como método humanizador, a Medicina Narrativa vem ao encontro do presente estudo, que propõe aos estudantes a escrita narrativa e reflexiva a respeito da humanização. 


\section{HiPÓTESE}

Apresenta-se como hipótese deste estudo que o significado de humanização para o estudante de Medicina ingressante é resultado da intersecção de seus valores sociais, institucionais e pessoais; está pautado em modelos familiares, sociais ou midiáticos; e é influenciado por experiências pessoais com situações de humanização ou desumanização. 


\section{OBJETIVOS}

\subsection{Objetivo Geral}

Compreender o significado de humanização para estudantes de Medicina no momento do seu ingresso no curso.

\subsection{Objetivos específicos}

1. Verificar a intersecção de seus valores sociais, institucionais e pessoais, como fatores de influência na construção do sentido de humanização.

2. Investigar qual a relação entre valores e tendências dos alunos apresentados nas narrativas e os valores e tendências propagados na sociedade contemporânea.

3. Examinar o conjunto de modelos familiares, sociais e midiáticos que permeiam o imaginário do estudante.

4. Relacionar as experiências pessoais de humanização e ou desumanização como fontes da construção da própria narrativa. 


\section{MÉTODO}

\subsection{Caracterização do estudo}

Este trabalho consiste em um estudo de caráter compreensivo interpretativo, realizado por meio de pesquisa qualitativa, com aplicação de entrevista semiestruturada, cujas respostas são as narrativas de estudantes de Medicina.

\subsection{Participantes}

Os participantes da pesquisa foram alunos de primeiro ano da Faculdade de Medicina da Universidade de São Paulo, ingressantes nesta faculdade no ano de 2016. O critério de inclusão foi estar matriculado no primeiro ano do curso. A participação foi voluntária e condicionada à assinatura do Termo de Consentimento Livre e Esclarecido (TCLE).

Foi garantido o anonimato dos respondentes e acesso aos resultados da pesquisa. Não houve oferta de pagamento ou qualquer vantagem pela participação, bem como a recusa em participar não incorreu em perda ou dano de qualquer natureza.

\subsection{Coleta de dados}

O universo dos estudantes ingressantes foi acessado ao término de uma atividade de aula teórica do currículo nuclear, sobre o tema do "Cuidado", na primeira semana do curso.

A pesquisa, seus objetivos e método foram apresentados aos alunos, e aqueles que aceitaram participar receberam um caderno de resposta contendo o TCLE, um questionário sociodemográfico e quatro questões abertas (Anexo A).

Os participantes permaneceram em um ambiente iluminado, livre de ruídos e interrupções e com conforto ergométrico, por 40 minutos, para preenchimento do caderno de respostas. 


\subsection{Análise de dados: da medicina narrativa à análise de conteúdo}

As diversas histórias que permearam as respostas às questões da entrevista trazem à tona valores, expectativas, experiências marcantes vividas pelos estudantes e opiniões por eles formadas antes de entrar no curso de graduação. Ao responder as questões sobre humanização, os estudantes revelaram aspectos de suas subjetividades, de suas realidades e de seus posicionamentos frente à sociedade atual. Evidência de que o debate sobre humanização transcende o âmbito da saúde e perpassa todos os tipos de relações sociais.

Para explorar as narrativas coletadas, utilizamos o quadro teórico da Medicina Narrativa, reconhecida por trabalhar com a elaboração de narrativas de doença ou relacionadas à prática médica, e, no caso deste estudo, à educação médica.

Quanto ao método utilizado para a análise das narrativas, refere-se à Análise de Conteúdo (Bardin, 2011; Henry e Moscovici, 1968), com base no referencial teórico da Medicina Narrativa. Apropriada para o estudo de ideias, opiniões, crenças, tendências, atitudes e significados, a Análise de Conteúdo consiste num conjunto de técnicas e procedimentos sistemáticos e objetivos de descrição dos conteúdos, de forma que permitam a categorização, a elaboração de inferências e a interpretação e discussão dos dados (Bardin, 2011; Henry e Moscovici, 1968). 


\section{RESULTADOS}

\subsection{Caracterização da amostra}

A amostra deste estudo consistiu no universo de 180 estudantes ingressantes na Faculdade de Medicina da Universidade de São Paulo, 13 estudantes estiveram ausentes no momento da coleta de dados e nove respondentes foram excluídos devido ao preenchimento incorreto do caderno de resposta (Anexo A). Foram incluídos no estudo 167 participantes, 67 do sexo feminino (40\%) e 100 do masculino (60\%). A idade dos participantes variou de 16 a 38 anos, com média de 20 anos (Figura 4).

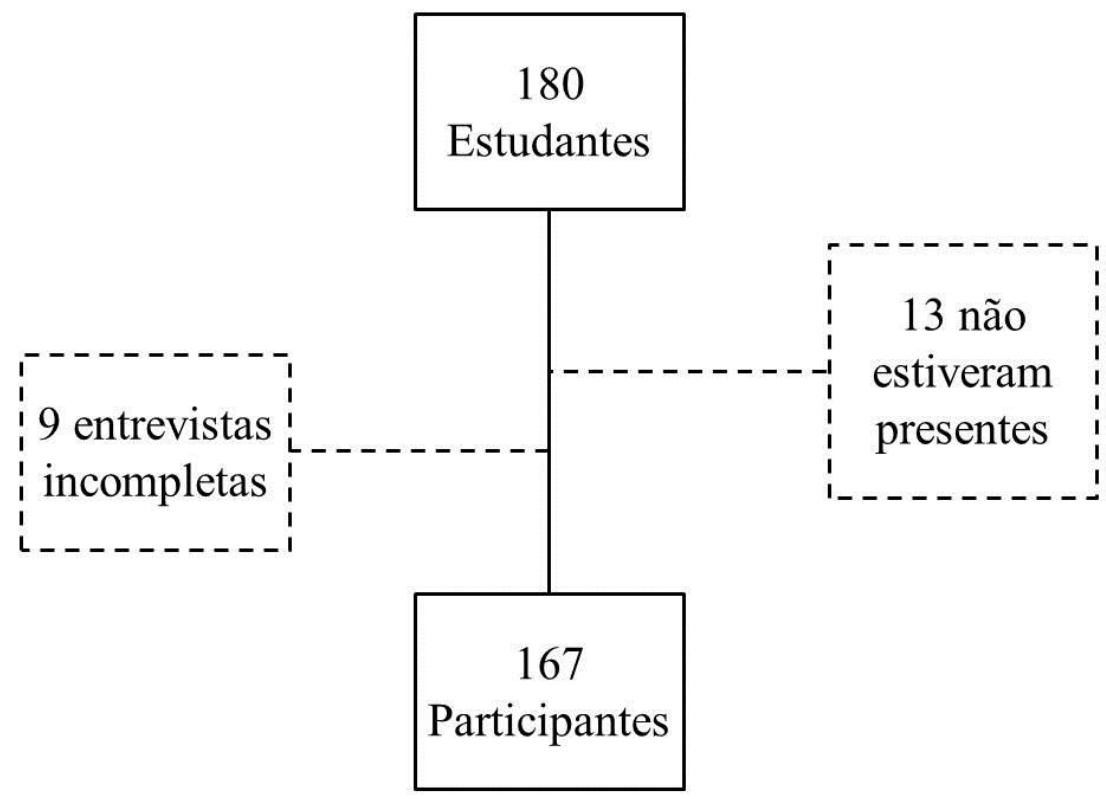

Figura 2: Fluxograma das perdas do estudo 


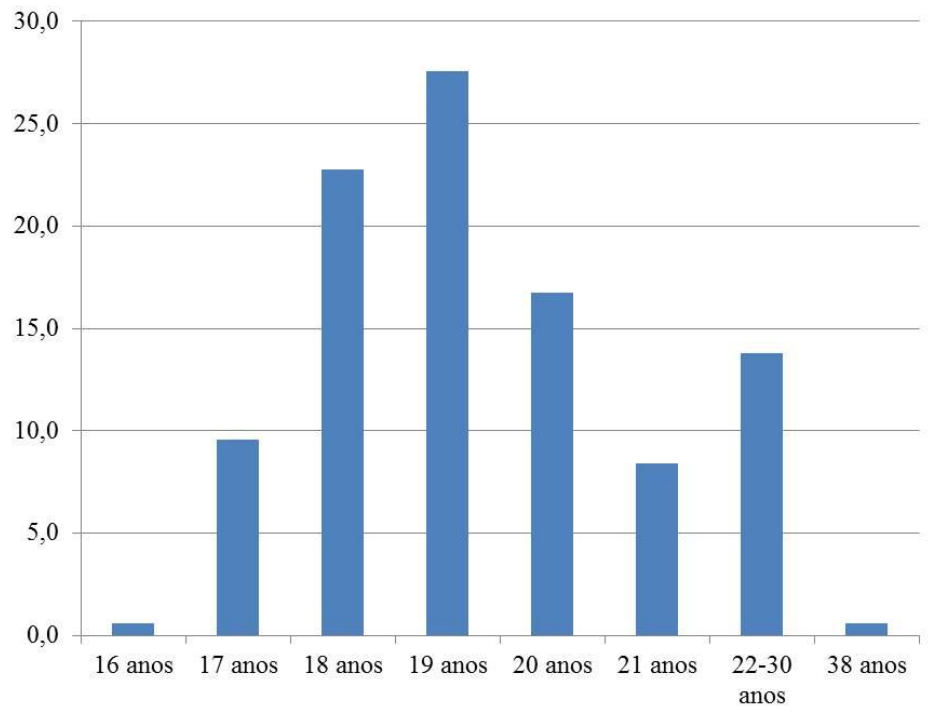

Figura 3: Representação gráfica da idade dos respondentes do estudo

Em relação à religião dos respondentes, $29 \%$ declararam-se católicos, $17 \%$ não declararam nenhuma religião, enquanto $14 \%$ declararam-se sem religião e $40 \%$ são pertencentes a outras religiões, sendo mais citadas as denominações espírita (7\%), cristã $(6 \%)$ e evangélica $(5 \%)^{5}$

\begin{tabular}{|c|}
\hline " Católico \\
\hline 匹 Não sabe / não declarou \\
\hline - Sem religião \\
\hline - Agnóstico \\
\hline$=$ Ateu \\
\hline Espírita \\
\hline Cristã \\
\hline Evangélico \\
\hline Outras religiões \\
\hline
\end{tabular}

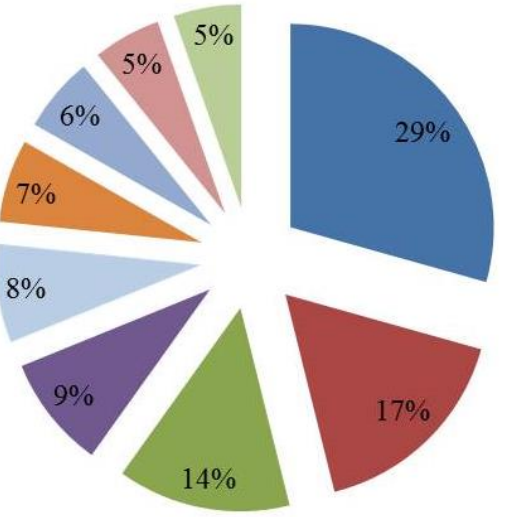

Figura 4: Representação gráfica das religiões praticadas pelos respondentes do estudo

\footnotetext{
${ }^{5}$ A classificação apresentada no gráfico a respeito das religiões foi elaborada a partir das respostas dos alunos. Eles mesmos diferenciam entre cristãos, evangélicos, católicos e outras religiões. Bem como se declaram sem religião, agnósticos, ou, simplesmente, deixam em branco o item religião no questionário, sem mencionar religião alguma, ou declaram que não sabem a sua religião.
} 
No que diz respeito à naturalidade, $52 \%$ dos respondentes proveem de São Paulo (capital), 26\% do interior do Estado São Paulo, 13\% de outros estados. Um respondente afirmou ser natural de Israel.
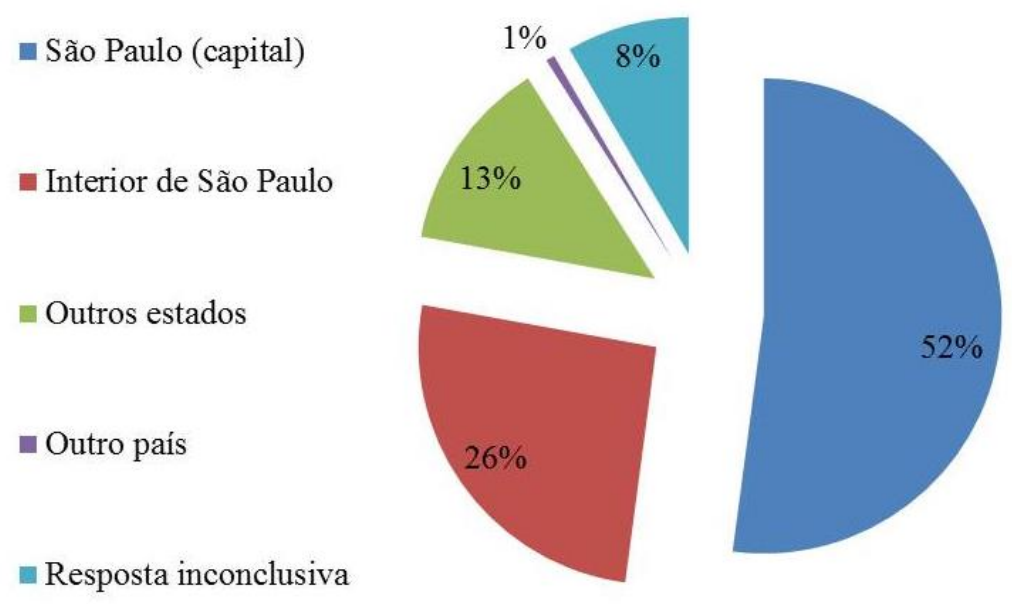

Figura 5: Representação gráfica da naturalidade dos respondentes do estudo

Quanto aos estudos realizados no decorrer do Ensino Fundamental, observou-se que $80 \%$ dos respondentes estudaram em escola particular, $14 \%$ em escola pública, e 6\% estudou tanto em escola particular como pública. Já com relação aos estudos realizados durante o Ensino Médio, verificou-se que 64\% dos respondentes estudaram em escola particular, $35 \%$ em escola pública, e $1 \%$ estudou tanto em escola particular como pública. 

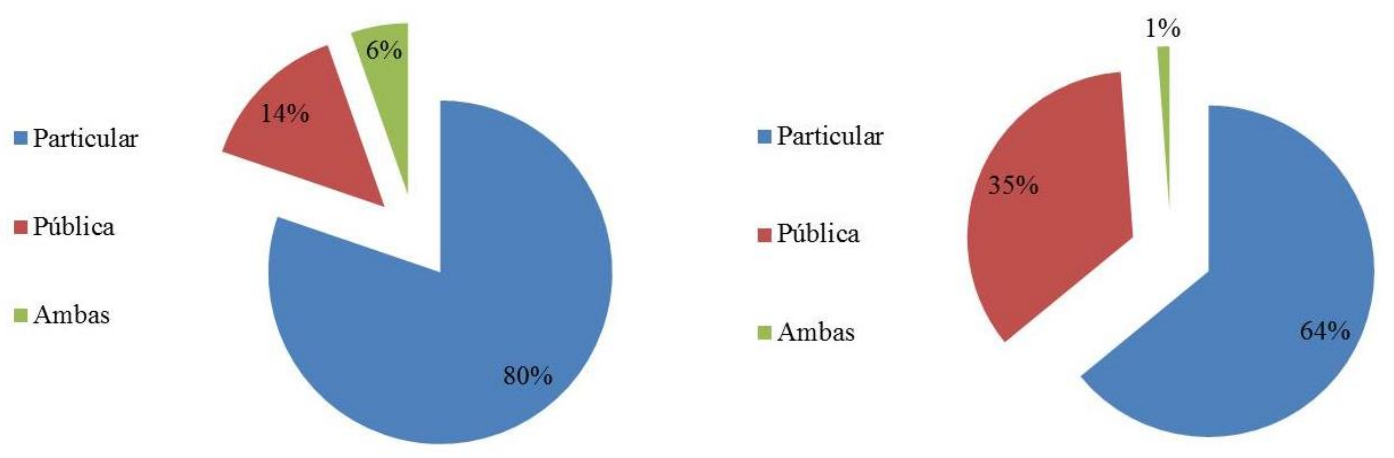

Figura 6: Representação gráfica da natureza jurídica das instituições de ensino fundamental e médio frequentadas pelos respondentes

Quanto à profissão dos pais dos respondentes, notou-se que $15 \%$ são médicos, $74 \%$ têm outras profissões, $5 \%$ estão desempregados ou são aposentados e $4 \%$ dos respondentes não informaram esta resposta. Em relação à profissão das mães dos respondentes, constata-se que $8 \%$ são médicas, $14 \%$ pertencem a outras profissões da área da saúde (como enfermeira, psicóloga, fisioterapeuta), 12\% são donas de casa, 5\% estão desempregadas ou são aposentadas, e $4 \%$ dos respondentes não informou esta resposta.
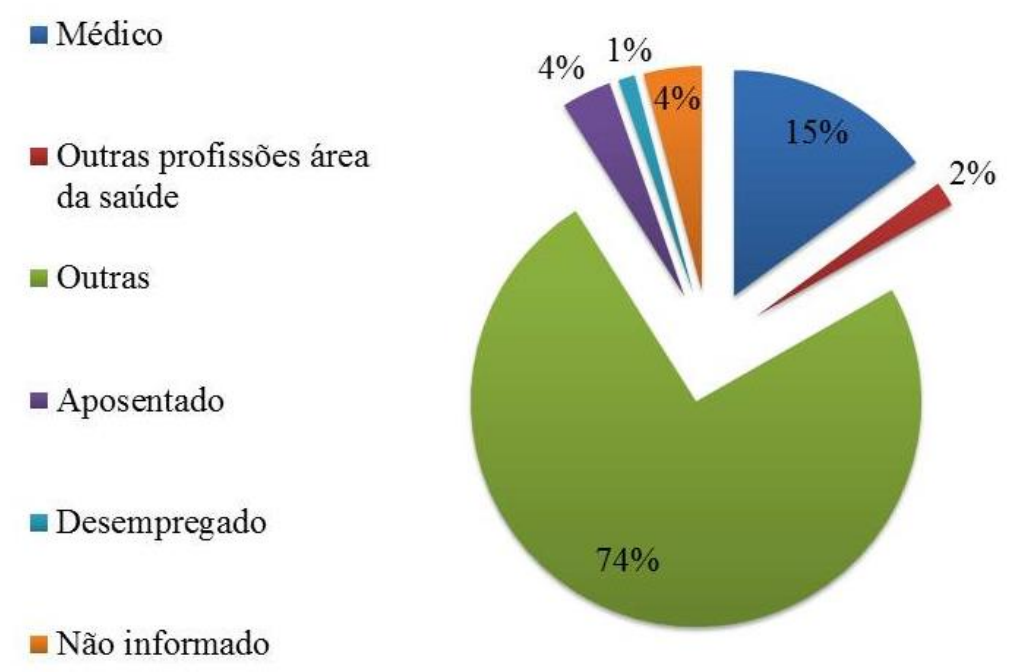

Figura 7: Representação gráfica da profissão dos pais dos respondentes do estudo 

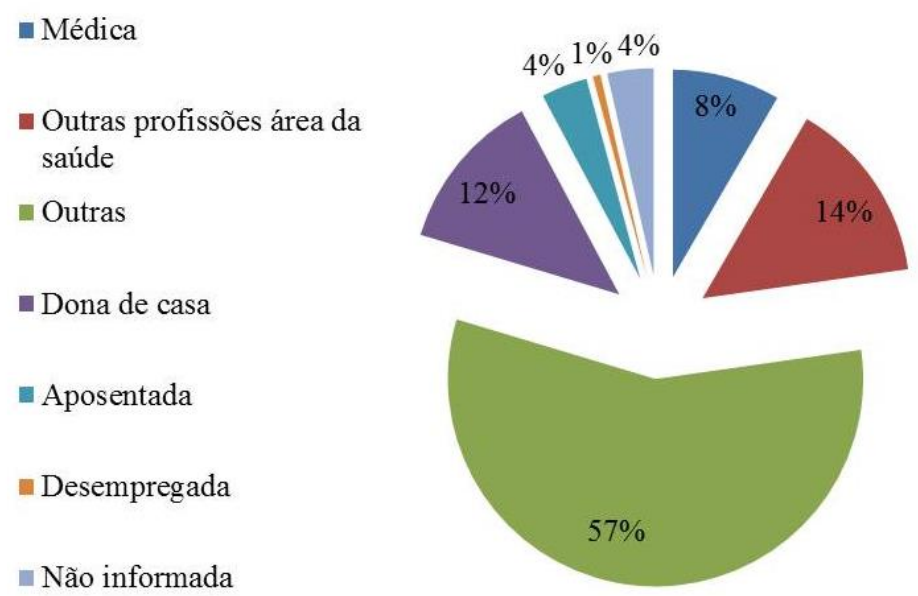

Figura 8: Representação gráfica da profissão das mães dos respondentes do estudo

Tendo em consideração a renda familiar, de acordo com a categorização do Instituto Brasileiro de Geografia e Estatística - $\mathrm{IBGE}^{6}, 22 \%$ pertencem à classe $\mathrm{A}, 30 \%$ à classe $\mathrm{B}, 25 \%$ à classe $\mathrm{C}$ e $8 \%$ à classe $\mathrm{D}$. Oito por cento dos respondentes não informaram a renda familiar.

"Classe A
nClasse B
$=$ Classe C
m Classe D
não informada
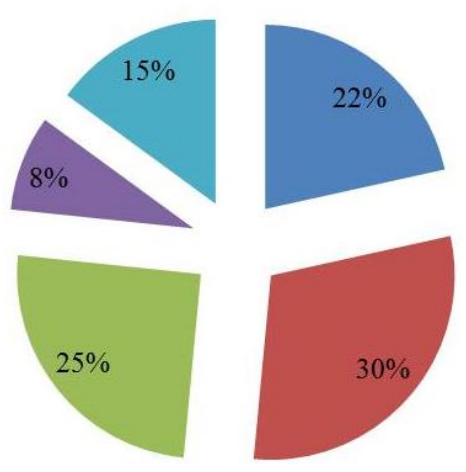

Figura 9: Representação gráfica da renda familiar dos respondentes do estudo

\footnotetext{
${ }^{6}$ Classe A: acima de 20 salários mínimos (acima de R $\$ 15.760,01$ ); Classe B: 10 a 20 salários mínimos (R\$7.880,01 a R\$15.760,00); Classe C: 4 a 10 salários mínimos (R\$3.152,01 a R\$7.880,00); Classe D: 2 a 4 salários mínimos $(\mathrm{R} \$ 1.576,01$ a $\mathrm{R} \$ 3.152,00)$. Dados referentes ao salário mínimo vigente no ano de 2016, ano da aplicação da pesquisa.
} 


\subsection{Análise Qualitativa}

5.2.1 Análise das respostas à questão 1: Qual experiência ou motivos levaram você a escolher a profissão médica?

Do conjunto de discursos referentes à primeira questão (Anexo B), que se refere às motivações para a escolha da profissão médica, emergiram quatro categorias: Experiências Pessoais, Interesse pelo ser humano integral, Aspecto sociopolítico da Medicina e Aspecto econômico da Medicina (Figura 10).

Com relação às experiências pessoais, as histórias de adoecimento próprio e de parentes foram reveladas como motivadoras da escolha profissional. Neste caso, tanto os bons atendimentos quanto os maus foram fatores de influência para os estudantes. Uma estudante mencionou que diante de um mau atendimento, ela percebeu a pessoa que ela não queria ser. Outros perceberam com admiração o esforço dos médicos para prover uma melhora na saúde de seus parentes. Eles mencionam seu fascínio pelos médicos que os atenderam, ou pelo fato de o médico estar numa posição em que pode oferecer conforto e esperança às pessoas.

Embora os estudantes tenham declarado ter tido influência dos pais médicos, sempre procuraram deixar claro que não houve pressão para a escolha da profissão, mas que foram influenciados pelos bons exemplos que viram e pelas histórias de atendimentos que ouviram no decorrer de sua vida. Outros estudantes expressaram ser a profissão médica um desejo de infância, pois relataram que, desde muito cedo, tinham muita vontade de cuidar das pessoas e ajudá-las de alguma forma.

A intenção de seguir a Medicina e reproduzir os modelos vivenciados veio do contato com seus pediatras ou com outros médicos que conheceram em algum momento de suas vidas, os quais demonstraram com seus pacientes um cuidado muito especial, dedicado, atencioso, que conforta e dá confiança aos pacientes. Neste tópico, os estudantes mencionam a vontade de agir da mesma maneira que aqueles médicos agiam em sua prática médica.

Diversos estudantes foram sensibilizados a escolher a carreira médica ao terem participado de ações sociais e trabalhos voluntários, percebendo a importância de se 
dedicar de forma profunda e, por vezes, mais específica às pessoas. Tendo sido colocados em contato com realidades diferentes das suas, com pessoas carentes ou em situações de vulnerabilidade social, podendo ouvir histórias de vida diferentes das suas, foram levados a optar por trabalhar na área da saúde.

Relativamente à categoria Interesse pelo ser humano integral, os estudantes demonstraram ver na Medicina a possibilidade de unir ciência e cuidado. Estes estudantes revelaram seu tanto o seu interesse pela vida, pelo corpo humano, pela ciência, quanto seu desejo de cuidar do outro, e de proporcionar conforto e ajudar as pessoas.

O desejo de ajudar pessoas e de melhorar as suas vidas é um tópico que apareceu frequentemente nas respostas. Alguns mencionam que é isto o que dá significado à vida, outros se viram fascinados pela possibilidade de aliviar o sofrimento das pessoas, e outros apresentam este desejo como uma necessidade premente de se doar para outras pessoas.

Expressaram a vontade de trabalhar de forma transdisciplinar, com várias áreas de conhecimento junto à Medicina, como química, física, história, artes e filosofia.

Outra categoria que emergiu das respostas à primeira questão foi o Aspecto sociopolítico da Medicina, em que os estudantes se mostraram interessados em transformar a sociedade por meio da prática médica, apresentaram reflexões a respeito do papel social do médico e manifestaram a vontade de contribuir para a melhoria do Sistema de Saúde brasileiro. Reconhecem a saúde como um direito do cidadão e se vêm como corresponsáveis por fazer valer este direito. Afirmaram conhecer a origem do Sistema Único de Saúde, mas enxergam a distância entre o projeto e a realização dos ideais originais, pretendendo, assim, trabalhar para que aqueles ideais sejam alcançados.

$\mathrm{Na}$ categoria Aspecto econômico da Medicina foi expresso o interesse nas oportunidades de trabalho e na estabilidade financeira, que permitem realizar outros projetos e alcançar ascensão social. 


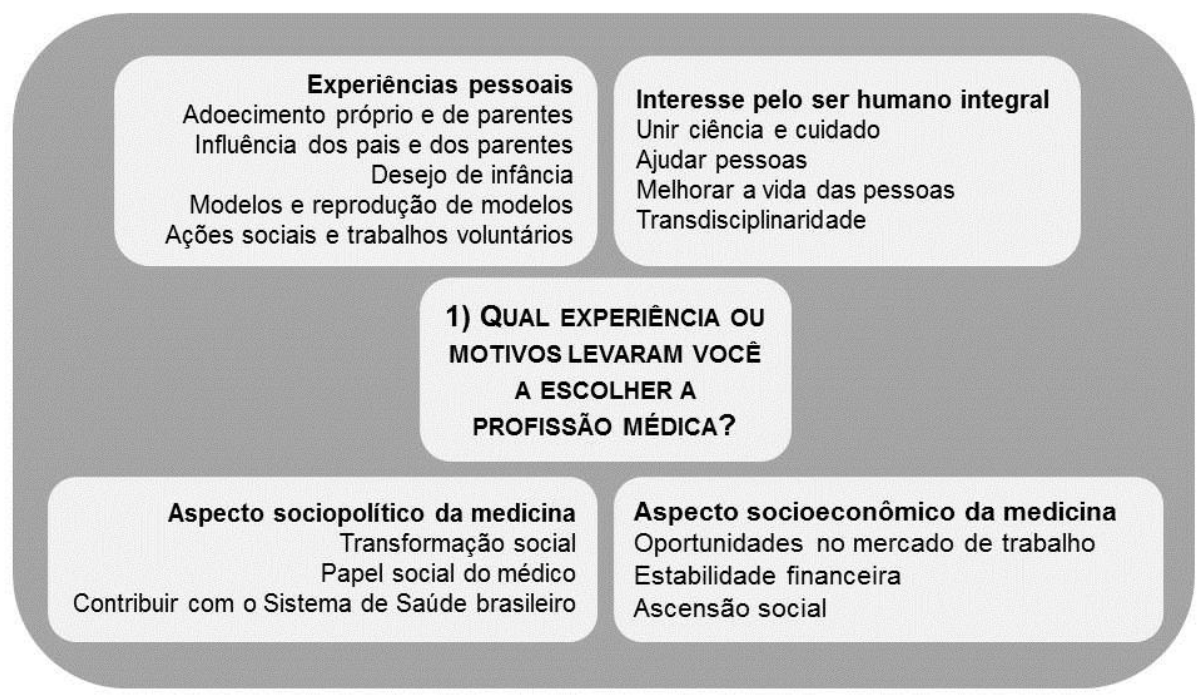

Figura 10: Categorias de análise referentes à questão 1: Qual experiência ou motivos levaram você a escolher a profissão médica? 
Tabela 1: Análise qualitativa relativa à pergunta 1 - Qual experiência ou motivos levaram você a escolher a profissão médica? Sua história é importante, utilize quantas linhas forem necessárias.

\begin{tabular}{|c|c|c|}
\hline Categorias & Itens & Exemplos de Discurso \\
\hline \multirow[t]{2}{*}{ Experiências Pessoais } & Adoecimento próprio & $\begin{array}{l}\text { "Levando em consideração as influências que tive, elas partiram de experiências do dia a dia, quando fui } \\
\text { muito bem atendida por profissionais da saúde, mas principalmente pelos maus atendimentos que eu e } \\
\text { minha família recebemos. Essas experiências ruins, em que o doutor sequer me cumprimentou ou me } \\
\text { deixou falar o que eu estava sentindo ou me permitiu questionar os diagnósticos e exames tiveram maior } \\
\text { peso em minha decisão porque me mostraram claramente a profissional, e, principalmente, a PESSOA que } \\
\text { eu não quero ser." (Aluna, } 19 \text { anos) } \\
\text { "Também percebi que sem a saúde eles [os dois avôs internados] não pareciam sequer a mesma pessoa de } \\
\text { antes e vi o quanto os médicos trabalham e se esforçam para garantir o bem-estar dos pacientes" (Aluna, } \\
18 \text { anos) } \\
\text { "O fascínio pelos meus médicos em consultas, tratamentos e cirurgias foi fundamental para despertar o } \\
\text { interesse pela medicina. O cuidado e o sentimento de confiança eram mútuos e demonstravam a beleza da } \\
\text { profissão. Justamente o fato de ter sido um paciente com cuidadores competentes abriu uma porta pra essa } \\
\text { escolha." (Aluno, } 17 \text { anos) }\end{array}$ \\
\hline & Adoecimento de parentes & $\begin{array}{l}\text { "Naquele caso, eu era seu acompanhante e num momento de extrema necessidade vi o profissional médico } \\
\text { atuando de forma além da prática técnica, no sentido de amparar o paciente numa situação emergencial. ... } \\
\text { Decidi pela carreira médica a fim de conseguir fornecer àquele que necessita de cuidados uma atenção que } \\
\text { vai além da técnica, abarcando aspectos mais humanísticos como o descompasso psicológico numa } \\
\text { situação tão delicada.” (Aluno, } 20 \text { anos) } \\
\text { “... meu avô paterno sofreu um acidente de carro e entrou em coma. A partir de então, comecei a } \\
\text { frequentar diariamente um hospital de minha cidade em que o meu avô estava na UTI. Assim, pude } \\
\text { observar, por alto, o trabalho do médico, o qual me chamou bastante atenção pela capacidade de conforto e } \\
\text { esperança que ele proporcionava para as pessoas." (Aluno } 19 \text { anos) }\end{array}$ \\
\hline
\end{tabular}


- Continuação Tabela 1 -

\begin{tabular}{|c|c|c|}
\hline Categorias & Itens & Exemplos de Discurso \\
\hline \multirow{3}{*}{ Experiências pessoais } & Influência dos pais & $\begin{array}{l}\text { "Acredito na influência familiar para a escolha da profissão. Não houve pressão dos pais, ao contrário, a } \\
\text { paixão demonstrada por eles me estimulou a escolhê-la." (Aluna, } 18 \text { anos) } \\
\text { "O fato de ambos meus pais serem médicos me influenciou muito. Mas não porque me pressionaram e sim } \\
\text { porque as experiências vividas por eles com coisas intrigantes e as inúmeras cartas de agradecimento } \\
\text { provindas dos pacientes me mostraram a beleza da profissão, ajudando sempre o outro, mesmo que com } \\
\text { palavras ao invés de medicamentos." (Aluno, } 18 \text { anos) } \\
\text { "Meu pai (meu veterano, inclusive) soube me demonstrar desde pequeno a importância da profissão } \\
\text { médica e de como superar os percalços da vida. Órfão de pai aos } 13 \text { anos, ingressou na FMUSP e foi meu } \\
\text { exemplo de um bom médico e meu incentivador." (Aluno, } 21 \text { anos) }\end{array}$ \\
\hline & Desejo de infância & $\begin{array}{l}\text { "A medicina é um sonho antigo que surgiu na infância a partir da vontade de cuidar dos outros. Quando } \\
\text { criança, sempre gostei de ajudar as pessoas e cuidar do meu irmão mais novo." (Aluna, } 20 \text { anos) } \\
\text { "Escolhi a profissão médica ainda muito pequena, por volta dos } 7 \text { anos de idade. Parte dessa escolha veio } \\
\text { da fascinação infantil com o trabalho médico e parte pela vontade de ajudar o próximo." (Aluna, } 18 \text { anos) }\end{array}$ \\
\hline & A intenção de reproduzir modelos & $\begin{array}{l}\text { “... houve uma grande influência do meu pediatra - médico extremamente atencioso e humano. Eu } \\
\text { sonhava em cuidar das pessoas como ele cuidava de mim.” (Aluna, } 20 \text { anos) } \\
\text { “... conheci uma médica incrível, suas consultas faziam as crianças rirem, as conversas eram inesquecíveis } \\
\text { (para os pacientes e para os alunos que ouviam), todos saiam sorrindo do consultório, o cuidado e carinho, } \\
\text { tanto com as crianças e suas famílias como com os alunos que acompanhavam, me marcaram. Achei uma } \\
\text { experiência incrível, que gostaria de repetir, propiciar o mesmo sentimento de conforto, de confiança que } \\
\text { ela conseguiu, para pacientes que m dia serão os meus.” (Aluna, } 19 \text { anos) } \\
\text { "Um outro fator que me fez sentir que realmente aquilo que eu queria fazer era medicina, foi o contato } \\
\text { com um grande médico e além disso uma excelente pessoa, um exemplo de entrega ao cuidado com o } \\
\text { próximo. Esse médico dedica a maior parte de sua semana para o cuidado com pessoas carentes... Esse } \\
\text { médico atende tais pacientes em seu consultório particular, totalmente sem custos... Sempre com muita } \\
\text { atenção, carinho e humanização. ... Isso me fez escolher a medicina, para um dia poder agir dessa maneira } \\
\text { e ser um meio de melhorar a vida de alguém.” (Aluno, } 18 \text { anos) }\end{array}$ \\
\hline
\end{tabular}


- Continuação Tabela 1 -

\begin{tabular}{|c|c|c|}
\hline Categorias & Itens & Exemplos de Discurso \\
\hline Experiências pessoais & $\begin{array}{l}\text { Ações sociais e trabalhos } \\
\text { voluntários realizados }\end{array}$ & $\begin{array}{l}\text { "Com aproximadamente } 14 \text { anos comecei a frequentar atividades voluntárias que me colocaram em } \\
\text { contato com outras realidades - realidades distantes da minha, e isso foi um motivador para que eu } \\
\text { escolhesse a medicina, pois eu entendi que através dessa profissão eu teria a oportunidade de transformar a } \\
\text { vida e a realidade de outras pessoas." (Aluna, } 20 \text { anos) } \\
\text { "Em } 2011 \text {, um dos trabalhos escolares pedidos pelas professoras foi uma ação voluntária com uma } \\
\text { instituição de auxílio a crianças carentes e em vulnerabilidade social... tive a chance de ouvir muitas dessas } \\
\text { crianças e suas histórias. Elas contavam sobre parentes ou conhecidos importantes em suas vidas que } \\
\text { estavam internados em hospitais públicos e sobre a dificuldade em seus tratamentos e atendimentos } \\
\text { médicos. ... pude perceber o quanto a saúde é determinante para o bem-estar das pessoas (às vezes mais do } \\
\text { que condições materiais), o que me levou a optar por uma área ligada ao cuidado em saúde." (Aluno, } 19 \\
\text { anos) }\end{array}$ \\
\hline \multirow[t]{2}{*}{$\begin{array}{l}\text { Interesse pelo ser } \\
\text { humano integral }\end{array}$} & Unir saber científico ao cuidado & $\begin{array}{l}\text { “... participei de um projeto social que me fez confiar mais na minha habilidade de lidar com pessoas de } \\
\text { forma humana. ... sempre gostei muito de estudar e do conhecimento científico, o que me fez escolher a } \\
\text { profissão médica, que reúne o saber e o cuidado.” (Aluna, } 21 \text { anos) } \\
\text { “... unindo meu desejo de contribuição para a sociedade, minha curiosidade de lidar com pessoas e meu } \\
\text { fascínio pela vida, eu decidi pela profissão médica.” (Aluna, } 18 \text { anos) } \\
\text { "Com o tempo, fui desenvolvendo certo pensamento crítico em relação ao que é ser médico, às } \\
\text { complicações da carreira, os estigmas, os problemas relacionados ao atendimento, ao acesso à saúde. A } \\
\text { partir de então, a medicina se tornou mais do que entender o funcionamento do corpo humano, mas a } \\
\text { possibilidade de proporcionar algum conforto para outra pessoa, ajudá-la de alguma forma.” (Aluna, } 19 \\
\text { anos) }\end{array}$ \\
\hline & Transdisciplinaridade & $\begin{array}{l}\text { "Medicina foi minha escolha porque é uma área do conhecimento humano na qual é possível encontrar } \\
\text { vertentes de diversas outras áreas, como as ciências humanas e expressões artísticas. Nesse contexto, uma } \\
\text { vez que sempre me atraí por matérias muito distintas entre si - como história, química, artes, filosofia e } \\
\text { física -, eu escolhi medicina porque espero ser passível de uma grande comunhão e fusão do } \\
\text { conhecimento humano." (Aluno, } 17 \text { anos) }\end{array}$ \\
\hline
\end{tabular}


- Continuação Tabela 1 -

\begin{tabular}{|c|c|c|}
\hline Categorias & Itens & Exemplos de Discurso \\
\hline \multirow[t]{2}{*}{$\begin{array}{l}\text { Interesse pelo ser } \\
\text { humano integral }\end{array}$} & Ajudar pessoas & $\begin{array}{l}\text { "Para mim, o ato de ajudar o outro, se doar pelo outro, é o que atribui algum significado à vida." (Aluna, } \\
19 \text { anos) } \\
\text { "Eu percebi a diferença que um médico pode fazer na vida das pessoas e o fato de poder ajudar alguém } \\
\text { diretamente e aliviar um pouco o sofrimento sempre me fascinou." (Aluna, } 18 \text { anos) } \\
\text { "Penso que o gosto, de certa forma precoce, pelo assunto [Medicina] foi apenas uma confirmação do que } \\
\text { eu desde pequeno quis ser: alguém que ajuda o outro. Vejo-me como uma pessoa disposta a ajudar e } \\
\text { cuidar; sinto-me bem em relacionar e criar afeto com outros..." (Aluno, } 20 \text { anos) }\end{array}$ \\
\hline & Melhorar a vida das pessoas & $\begin{array}{l}\text { "A possibilidade de poder contribuir para melhorar a qualidade de vida dos meus próximos ultrapassa } \\
\text { meros gostos por equações químicas ou sistemas biológicos. Precisava continuar nesse caminho: precisava } \\
\text { me tornar médico." (Aluno, } 19 \text { anos) }\end{array}$ \\
\hline \multirow[t]{2}{*}{$\begin{array}{l}\text { Aspecto sociopolítico } \\
\text { da Medicina }\end{array}$} & Transformação social & $\begin{array}{l}\text { "A medicina foi a [profissão] que mais me atraiu. Não só pelo belo trabalho que um médico faz, mas } \\
\text { também pela ótima sensação de que eu poderia contribuir para melhorar o Brasil. ... com a medicina, eu } \\
\text { senti que conseguiria exercer a profissão sem duvidar do potencial da prática médica em melhorar a } \\
\text { sociedade." (Aluna, } 19 \text { anos) } \\
\text { "A escolha da profissão médica se deve ao meu interesse em ajudar o próximo e contribuir para certa } \\
\text { mudança social. Na medicina posso encontrar não só aspectos biológicos como também aspectos mentais e } \\
\text { sociais, e esses dois últimos foram importantes na minha decisão. Durante meu ensino médio, tive contato } \\
\text { com discussões reflexivas e questionadoras, o que me levou a buscar essa essência na profissão médica." } \\
\text { (Aluno, } 18 \text { anos) }\end{array}$ \\
\hline & Papel social do médico & $\begin{array}{l}\text { "Acredito que deva ser extremamente gratificante poder ajudar as pessoas dessa forma e assumir as } \\
\text { responsabilidades sociais de um médico." (Aluna, } 22 \text { anos) } \\
\text { "O interesse pelo conteúdo [biológicas] somou-se à possibilidade de cumprir um papel social que a } \\
\text { profissão fornece e cuidar da saúde, direito fundamental a todos da população." (Aluna, } 19 \text { anos) }\end{array}$ \\
\hline
\end{tabular}


- Continuação Tabela 1 -

\begin{tabular}{|c|c|c|}
\hline Categorias & Itens & Exemplos de Discurso \\
\hline $\begin{array}{l}\text { Aspecto sociopolítico } \\
\text { da Medicina }\end{array}$ & $\begin{array}{l}\text { Contribuir para a melhora do } \\
\text { sistema de saúde brasileiro }\end{array}$ & $\begin{array}{l}\text { “... ao me deparar com as precárias condições de saúde do nosso país, me senti motivada a tentar mudar } \\
\text { essa realidade e prover um atendimento digno às pessoas.” (Aluna, } 20 \text { anos) } \\
\text { "As idas a hospitais públicos como paciente me proporcionaram experiências positivas e negativas a } \\
\text { respeito do SUS que me incentivaram a participar como profissional buscando a melhora do sistema para } \\
\text { que os ideais que originaram o projeto sejam colocados em prática.” (Aluna, } 22 \text { anos) } \\
\text { “...sentia que eu poderia contribuir com a saúde no Brasil com a minha sensibilidade.” (Aluna, } 20 \text { anos) }\end{array}$ \\
\hline \multirow{3}{*}{$\begin{array}{l}\text { Aspecto econômico da } \\
\text { Medicina }\end{array}$} & $\begin{array}{l}\text { Oportunidades amplas no mercado } \\
\text { de trabalho }\end{array}$ & $\begin{array}{l}\text { “... levei em conta o grande espaço no mercado de trabalho.” (Aluna, } 20 \text { anos) } \\
\text { “... fui pesquisando cada vez mais sobre as áreas de atuação médica e a amplitude dessa profissão.” } \\
\text { (Aluno, } 19 \text { anos) }\end{array}$ \\
\hline & Estabilidade Financeira & $\begin{array}{l}\text { "Essa opção pela medicina foi distante de busca por qualquer prestígio social, mas contou a possibilidade } \\
\text { de estabilidade financeira." (Aluno, } 19 \text { anos) } \\
\text { “... a estabilidade financeira que essa profissão pode me proporcionar condiz com meus objetivos de vida, } \\
\text { que incluem financiamento de projetos artísticos voltados para a reabilitação de pacientes...” (Aluno, } 17 \\
\text { anos) }\end{array}$ \\
\hline & Ascensão social & $\begin{array}{l}\text { "Tal escolha se deveu em muito à lembrança de uma infância conturbada por problemas econômicos." } \\
\text { (Aluna, } 20 \text { anos) } \\
\text { "Em grande medida a faculdade de medicina é uma escolha baseada em minhas origens sociais e histórico } \\
\text { de vida. ... cursar uma universidade pública de qualidade também é um importante vetor de transformação } \\
\text { não só pessoal e financeira mas também no próprio contexto de desigualdade social do país. ... O orgulho } \\
\text { de ser filho de nordestino com um imigrante japonês com poucas perspectivas, sendo o primeiro a se } \\
\text { graduar reflete em toda a sociedade.” (Aluno, } 17 \text { anos) }\end{array}$ \\
\hline
\end{tabular}


5.2.2 Análise das respostas à questão 2: Humanizar é ... Complete com suas palavras.

Para os participantes desta pesquisa, humanizar é ter atitudes mais humanas. Suas respostas foram categorizadas em: compreensão humana, atitudes humanas, contextos humanos e tratamento humano (Anexo C).

Quanto à Compreensão humana, o contexto social, emocional e a história pessoal foram entendidos como aspectos relevantes na relação entre médico e paciente. Para os estudantes, é importante levar em consideração não só a fisiologia, mas os aspectos psicológicos e sociais do paciente; é necessário que o médico estabeleça um vínculo emocional e tenha interesse em conhecer a história dos pacientes. É importante que o médico perceba que as necessidades dos pacientes vão além das necessidades físicas, e que o profissional se dedique a cuidar do paciente levando em consideração os aspectos emocionais, sociais e de saúde.

Com relação às Atitudes humanas, os estudantes demonstraram se importar com o acolhimento, o conforto, a promoção do bem-estar, o respeito e com a valorização da empatia. De acordo com a percepção deles, o médico deve oferecer acolhimento, bem como o consultório deve ser um lugar acolhedor. Faz parte do papel do médico cuidar da saúde do paciente e, ao mesmo tempo, confortá-lo. O médico precisa se preocupar com o bem-estar geral do paciente, e deve tratá-lo com respeito, numa relação amigável. O profissional da medicina deve ter a consciência de que no atendimento médico há pessoas cuidando de pessoas, ou seja, a empatia deve ser um norteador desta relação.

Tendo em consideração a categoria Contextos humanos, os aspectos expostos foram a singularidade e a complexidade humanas. Ressaltam a importância de se considerar os aspectos individuais, do paciente, a sua condição ímpar e única. Revelam sua percepção com relação à complexidade do ser humano, que tem suas histórias e seus valores diferentes uns dos outros, e expressam que o conhecimento técnico, por si só, não abarca toda esta complexidade. Os estudantes mencionam a importância de o médico tratar o doente, e não a doença, colocar o doente à frente da doença e de sempre se lembrar de que antes de ser um doente, o paciente é uma pessoa, com história, medos, angústias e sonhos. Outro aspecto emergente nesta categoria foi a necessidade de uma horizontalidade na relação entre médico e paciente, entendendo-se que o contato é humano-humano e não médico-paciente. A observação da necessidade de se perceber a 
si mesmo na relação com o outro também foi apontada, por meio da observação do outro como uma extensão de si próprio, através da aceitação de que ambos aprendem nesta relação e por meio da atitude de permitir que o outro tenha acesso a si mesmo.

No tocante à categoria do Tratamento humano, os estudantes ressaltaram a importância de se "ir além da dimensão técnica", de se "ultrapassar a barreira do conhecimento técnico", observando todas as dimensões que abrangem a vida do paciente e que podem estar interferindo em sua saúde. Descoisificar a relação médicopaciente, tratando o outro como pessoa, não permitir que o atendimento seja maquinizado ou automatizado também foram preocupações manifestadas nas respostas.

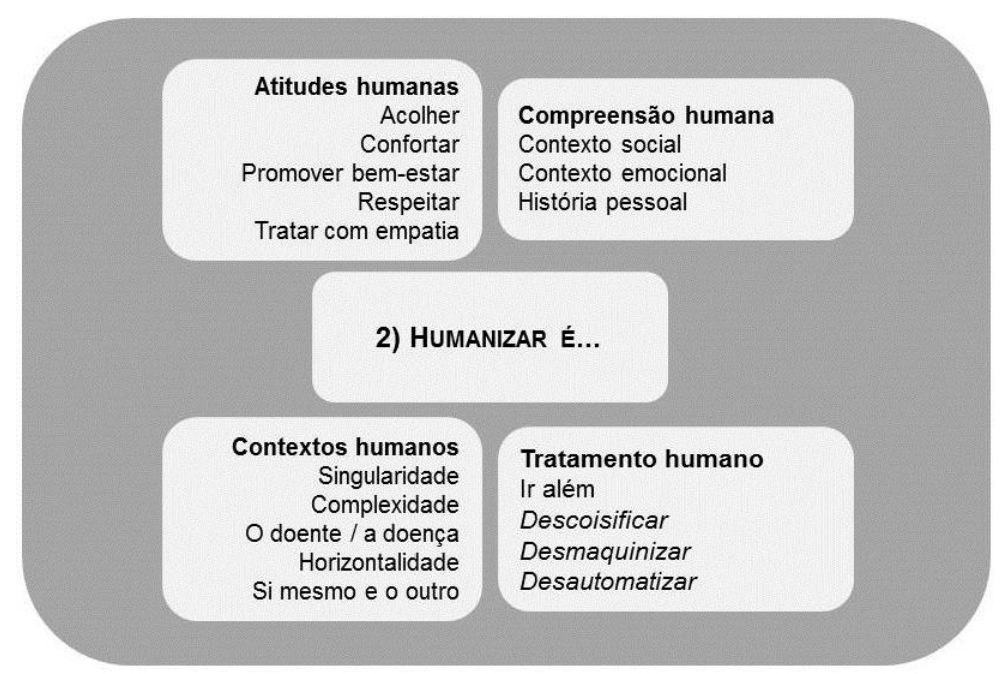

Figura 11: Categorias de análise referentes à questão 2: Humanizar é... Complete com suas palavras 
Tabela 2: Análise qualitativa relativa à pergunta 2 - Humanizar é ... Complete com suas palavras.

\begin{tabular}{|c|c|c|}
\hline Categorias & Itens & Exemplos de Discurso \\
\hline \multirow{3}{*}{ Compreensão Humana } & Contexto social & $\begin{array}{l}\text { "Humanizar é tornar o tratamento com as pessoas mais sensível, levando a atenção para o âmbito } \\
\text { psicológico e social do paciente, ou seja, ao seu estilo de vida, seus sentimentos, sua história, pelo que ele } \\
\text { passa até chegar ao posto de saúde." (Aluna, } 17 \text { anos) } \\
\text { "Humanizar é ouvir o paciente em esferas que excedem o âmbito médico, como a esfera pessoal, cultural e } \\
\text { psicológica. Os sintomas de um paciente podem surgir, ou serem potencializados por fatores não } \\
\text { fisiológicos. A humanização, portanto, permite um diagnóstico e um tratamento amplo, completo e total." } \\
\text { (Aluno, } 25 \text { anos) }\end{array}$ \\
\hline & Contexto emocional & $\begin{array}{l}\text { "Humanizar é olhar o outro sabendo que é um ser que sofre, que ama, que odeia e que precisa de ajuda...” } \\
\text { (Aluna, } 20 \text { anos) } \\
\text { "Tratar o próximo com respeito, atenção e dedicação, considerando-o como um ser humano que possui } \\
\text { suas necessidades e problemas, que podem ser sanados ou aliviados, e não o considerando como um } \\
\text { simples objeto de estudo sem levar em conta seus sentimentos, sensações, medos, angústias e tudo o mais } \\
\text { que faz parte do ser humano." (Aluno, } 26 \text { anos) }\end{array}$ \\
\hline & História pessoal & $\begin{array}{l}\text { "É enxergá-la [a pessoa] empaticamente e tratá-la como seu igual, respeitando suas dúvidas e anseios e } \\
\text { buscando compreender sua história - ainda que esta não seja compatível com a nossa ou mesmo que traga } \\
\text { valores distintos àqueles que acreditamos." (Aluna, } 20 \text { anos) } \\
\text { "Humanizar é enxergar o outro. É saber, ou querer saber, do outro - sua história, seus desejos, sonhos, } \\
\text { medos, angústias. ... É tratar, como pessoa, o outro, considerando suas 'bagagens' histórica, cultural, } \\
\text { social." (Aluno, } 20 \text { anos) }\end{array}$ \\
\hline
\end{tabular}


- Continuação Tabela 2 -

\begin{tabular}{|c|c|c|}
\hline Categorias & Itens & Exemplos de Discurso \\
\hline \multirow{5}{*}{ Atitudes Humanas } & Acolher & $\begin{array}{l}\text { "Humanizar é cuidar dos cidadãos de forma que esses indivíduos sejam acolhidos.” (Aluna, } 20 \text { anos) } \\
\text { "Humanizar é transformar o ambiente do consultório ou do hospital em um lugar acolhedor e feliz." } \\
\text { (Aluno, } 19 \text { anos) }\end{array}$ \\
\hline & Confortar & $\begin{array}{l}\text { "Prestar um atendimento que ... consiga atingir o paciente de forma a confortá-lo..." (Aluno, } 20 \text { anos) } \\
\text { "É mostrar que o paciente não apenas está sendo tratado, mas também cuidado e confortado." (Aluno, } 19 \\
\text { anos) }\end{array}$ \\
\hline & Promover bem-estar & $\begin{array}{l}\text { "Humanizar é cuidar da pessoa e de suas carências para receber sua confiança e proporcionar o bem-estar } \\
\text { que ela busca." (Aluna, } 22 \text { anos) } \\
\text { "É tratar o paciente como pessoa, a qual precisa do bem-estar para viver plenamente, e não apenas } \\
\text { sobreviver." (Aluna, } 18 \text { anos) }\end{array}$ \\
\hline & Respeitar & $\begin{array}{l}\text { "Tratar com respeito... a humanização deve contar com uma relação amigável entre paciente e } \\
\text { profissional. O cuidado com ambas as partes conduzirá a relação/consulta a um estágio de respeito, } \\
\text { atenção e carinho." (Aluno, } 19 \text { anos) }\end{array}$ \\
\hline & Tratar com empatia & $\begin{array}{l}\text { "Deve-se entender que além da relação médico-paciente, encontra-se pessoas cuidando de pessoas, ou } \\
\text { seja, somos humanos, devemos manter nosso lado humano e empático vivo dentro de nós, mostrando a } \\
\text { importância que cada um tem e a atenção de que cada um é merecedor." (Aluna, } 22 \text { anos) } \\
\text { "Humanizar é ter empatia. Compadecer com as dores dos outros; regozijar-se com a alegria também." } \\
\text { (Aluno, } 19 \text { anos) }\end{array}$ \\
\hline
\end{tabular}


- Continuação Tabela 2 -

\begin{tabular}{|c|c|c|}
\hline Categorias & Itens & Exemplos de Discurso \\
\hline \multirow{4}{*}{ Contextos Humanos } & Singularidade & $\begin{array}{l}\text { "Humanizar é conjugar empatia à técnica de forma a considerar... os aspectos humanos, individuais e } \\
\text { únicos do sujeito com o qual se está interagindo. Humanizar, dessa forma, é potencializar o auxílio." } \\
\text { (Aluna, } 19 \text { anos) } \\
\text { "Atentar à condição ímpar do outro, tratá-lo como um indivíduo com angústias e sonhos válidos e cuidá-lo } \\
\text { de forma dedicada, virtuosa e tolerante." (Aluna, } 18 \text { anos) }\end{array}$ \\
\hline & Complexidade & $\begin{array}{l}\text { "Humanizar é compreender que o outro é um ser humano tão complexo quanto si mesmo com sua história, } \\
\text { angústias, seus desejos, seus valores e tratá-lo como tal." (Aluna, } 18 \text { anos) } \\
\text { "Humanizar é lembrar que apenas o conhecimento técnico não abarca a complexidade humana. ... } \\
\text { Humanizar é prezar pela vida valorizando o indivíduo e suas complexidades, estabelecendo relações } \\
\text { interpessoais efetivas e não superficiais." (Aluno, } 17 \text { anos) }\end{array}$ \\
\hline & O doente / a doença & $\begin{array}{l}\text { “... cuidar dos pacientes entendendo claramente que antes de serem portadores de uma doença, eles são } \\
\text { pessoas e merecem respeito, atenção e o comprometimento do profissional da saúde em dar o melhor de } \\
\text { si." (Aluna, } 19 \text { anos) } \\
\text { "Humanizar é colocar o ser humano à frente da doença, é pensar naquela pessoa como um todo (visão } \\
\text { holística)..." (Aluno, } 18 \text { anos) }\end{array}$ \\
\hline & Horizontalidade & $\begin{array}{l}\text { "Humanizar é respeitar o paciente qualquer que seja sua formação; social, profissional e moral; e tentar ao } \\
\text { máximo deixar claro que ambos (médico e paciente) são humanos e que ambos são falhos e que não é } \\
\text { porque um passou anos se qualificando para tratar outros que ele é melhor, e que muito menos possui o } \\
\text { direito de legitimação para subjugar ou desrespeitar o outro." (Aluna, } 19 \text { anos) } \\
\text { "O contato humano-humano (não médico-paciente), horizontal, é muito rico. É por meio dele que se pode } \\
\text { conhecer e reconhecer as semelhanças entre nós, a essência que nos torna vivos." (Aluna, } 18 \text { anos) }\end{array}$ \\
\hline
\end{tabular}


- Continuação Tabela 2 -

\begin{tabular}{|c|c|c|}
\hline Categorias & Itens & Exemplos de Discurso \\
\hline Contextos Humanos & Si mesmo e o outro & $\begin{array}{l}\text { "Não temer o olhar alheio, é se enxergar, tal qual reflexão, no seu semelhante. É se arriscar além da bolha } \\
\text { impenetrável na qual nos aprisionamos, é negar o egocentrismo, é entender o outro como uma extensão do } \\
\text { próprio ser. É desconstruir as fortalezas que construímos em torno de nós mesmos; é permitir ao outro um } \\
\text { mecanismo de entrada." (Aluna, } 18 \text { anos) } \\
\text { "Humanizar é entender que a relação médico-paciente é uma via de mão dupla. É entender que tanto o } \\
\text { médico quanto o paciente aprendem em uma consulta. Humanizar é captar tudo aquilo que não está } \\
\text { explícito, é perceber as dores e angústias mais escondidas e ter a capacidade de lidar com elas." (Aluno, } 21 \\
\text { anos) } \\
\text { "É difícil enxergar o mundo de outra perspectiva que não a de nossos olhos, mas é uma experiência } \\
\text { fascinante." (Aluno, } 19 \text { anos) }\end{array}$ \\
\hline \multirow[b]{2}{*}{ Tratamento Humano } & Ir além & $\begin{array}{l}\text { "Prestar um atendimento que ultrapasse a barreira do conhecimento técnico e consiga atingir o paciente de } \\
\text { forma a confortá-lo..." (Aluno, } 20 \text { anos) } \\
\text { “... ver além da dimensão técnica, observando que por trás de uma doença ou diagnóstico existe também } \\
\text { um ser humano, imerso em suas questões étnicas, socioeconômicas e culturais." (Aluna, } 18 \text { anos) }\end{array}$ \\
\hline & $\begin{array}{l}\text { Descoisificar } \\
\text { Desmaquinizar } \\
\text { Desautomatizar }\end{array}$ & $\begin{array}{l}\text { "Estar presente, em um estado de 'mindfulness', ao falar com o paciente, realmente ouvindo o que ele tem } \\
\text { a dizer ao invés de descartar informações e atender de forma automática." (Aluna, } 22 \text { anos) } \\
\text { "Humanizar é, principalmente, deixar de fazer com que o paciente seja uma coisa, ou seja, somente um } \\
\text { objeto de estudo e tratamento. Humanizar é fazer com que o paciente sinta-se como pessoa, tratado com } \\
\text { respeito e possuindo direito por boas condições em seu atendimento." (Aluna, } 18 \text { anos) } \\
\text { "Confortar, impedindo a maquinização da profissão médica, oferecendo outra esfera de cuidado no } \\
\text { tratamento..." (Aluno, } 17 \text { anos) }\end{array}$ \\
\hline
\end{tabular}

- Conclusão da Tabela 2 - 
5.2.3 Análise das respostas à questão 3: Narre uma experiência de humanização ou desumanização vivida por você.

Foram narradas pelos estudantes experiências relacionadas ou não à área da saúde. As categorias de análise nesta questão foram: Experiências de Desumanização e Experiências de Humanização.

$\mathrm{Na}$ categoria Desumanização foram citadas situações em que o médico não olhou nos olhos do paciente enquanto o recebia e o atendia, olhando apenas para o prontuário a ser preenchido no computador. Situações em que o médico tratou com descaso a história do paciente ou o sofrimento deste e de seus familiares. E foram também mencionados erros de diagnósticos com consequências ao paciente.

$\mathrm{Na}$ categoria Humanização foram citadas experiências que os estudantes viveram com ações sociais voltadas a comunidades carentes ou minorias. Outros estudantes narraram experiências que vivenciaram quando visitaram instituições de saúde voluntariamente, como o Instituto da Criança ou o GRAAC, e experimentaram por si mesmos a humanização. Diversos estudantes mencionaram as experiências que tiveram no Ambulatório Social da semana de recepção da FMUSP, quando tiveram a oportunidade de contar histórias para crianças internadas no Instituto da Criança, puderam entrar em contato com pacientes e perguntar a eles o que para eles era um bom médico e ressaltaram que esta experiência trouxe à tona para os estudantes valores e princípios humanistas. Outras experiências de humanização estão relacionadas à percepção do médico em relação ao paciente, à atenção e à comunicação adequada na relação entre médico e paciente. Neste caso, o interesse, a delicadeza, a calma, a atenção e o ato de ouvir são emblemáticos para os estudantes.

Tanto as experiências de humanização quanto de desumanização revelaram situações das relações humanas contemporâneas. Estudantes revelam situações de malestar entre as pessoas cotidianamente no transporte público ou ao se depararem com a miséria nas ruas da cidade. Por outro lado, em pequenas ações cotidianas, como ajudar amigos nos estudos, receber suporte e carinho dos pais, fazer novas amizades e manter as antigas, o ato de conhecer o outro e a cordialidade são expressões de humanização nas relações humanas contemporâneas. 


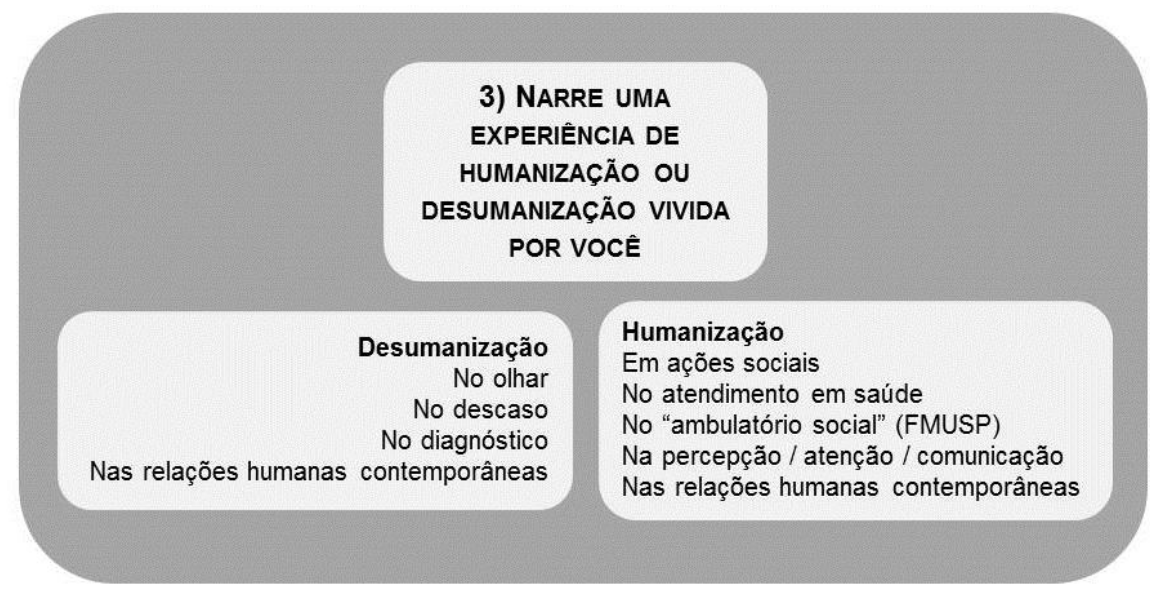

Figura 12: Categorias e itens de análise referentes à questão 3: Narre uma experiência de humanização ou desumanização vivida por você. 
Tabela 3: Análise qualitativa relativa à pergunta 3 - Narre uma experiência de humanização ou desumanização vivida por você.

\begin{tabular}{|c|c|c|}
\hline Categorias & Itens & Exemplos de Discurso \\
\hline & No olhar & $\begin{array}{l}\text { “... Contudo, dos mais de seis médicos pelos quais passei nos últimos anos, no máximo dois olharam nos } \\
\text { meus olhos e me trataram como uma pessoa que também tem seus medos e inseguranças.” (Aluna, } 18 \\
\text { anos) } \\
\text { "Sofri uma experiência de desumanização na qual, ao ser atendido por um clínico, este constantemente } \\
\text { digitou no seu computador, nem sequer perguntando meu nome na entrada no consultório. Não houve } \\
\text { contato visual e a desatenção do médico era tamanha que tive que repetir sintomas.” (Aluno, } 19 \text { anos) }\end{array}$ \\
\hline Desumanização & No descaso & $\begin{array}{l}\text { "Tenho uma tia distante médica, que sempre se refere a seus pacientes como simples doenças, } \\
\text { constantemente fala que prefere trabalhar na UTI pois há menos conversa com pacientes, não se relaciona } \\
\text { com eles, e ainda conta, em tom de deboche, queixas que ouve daqueles que atende. Desde cedo a relação } \\
\text { dela com seus pacientes me trazia aflição. Como alguém que cuida de doentes em situações tão graves } \\
\text { pode ter aversão à relação com eles?" (Aluna, } 19 \text { anos) } \\
\text { "Durante a consulta, o médico não me perguntou meu nome, não se interessou sobre a minha história, } \\
\text { simplesmente restringiu-se à dor que eu sentia." (Aluno, } 18 \text { anos) } \\
\text { "Em um hospital privado, havia um familiar meu que estava passando por diversos exames para a } \\
\text { realização de cirurgia. O episódio de desumanização deu-se quando o médico responsável pelo aval a ser } \\
\text { dado ao meu familiar sequer se deu ao trabalho de explicar ao paciente ou à família os resultados dos } \\
\text { exames e seus significados, em um comportamento de completo descaso com a situação emocional das } \\
\text { pessoas envolvidas." (Aluno, } 17 \text { anos) }\end{array}$ \\
\hline
\end{tabular}


- Continuação Tabela 3 -

No diagnóstico

\section{Desumanização}

Nas relações humanas

contemporâneas

Humanização
"Pronto socorro público da cidade de Taubaté, São Paulo, uma menina de 7 anos esperava na sala lotada com dores pulsantes da região abdominal. [...] A menina esperava angustiada, havia passado já por aquele lugar nos dois dias anteriores, fora diagnosticada como intoxicação alimentar nas duas primeiras, mas a dor não passou. [...] Finalmente, na consulta daquele dia o outro médico foi mais compreensivo, tocou-a, escutou atentamente o caso exposto pelos familiares. Ela foi encaminhada com urgência para a cirurgia. Era apendicite." (Aluno, 19 anos)

"Em um domingo estava indo a uma festa com minha família quando vi uma menina pedindo esmola na rua. Enquanto eu estava arrumada, ia me divertir e comer na festa, essa menina, que deveria ter a minha idade, estava na rua, com roupas velhas, sem dinheiro, sem comida, exposta ao crime e à violência, sem moradia e sem ter oportunidade de ir à escola. Ela não parecia um ser humano, mas somente algo no meio da rua. Para mim essa foi uma experiência de desumanização, pois a menina não tinha os direitos e condições básicas de qualquer ser humano." (Aluna, 18 anos)

"Uma experiência de desumanização se deu no metrô de São Paulo [...]. [...] e quando o trem chegou, na porta do lado da minha saiu uma senhora passando muito mal e se deitou na plataforma de modo a obstruir a passagem. [...] as pessoas dessa porta se desviavam para entrar no trem sem dar atenção à senhora, e logo um funcionário foi 'ajudá-la'. Claramente tal ajuda não visava cuidar desta senhora, mas sim desobstruir a passagem.” (Aluno, 18 anos)

"Junto com mais 2 colegas, deram-me a oportunidade de planejar o curso de inglês [do EJA] e dar as aulas. [...] Conheci, ao longo do tempo, a história de todos os meus alunos, tive que entender a realidade social deles, muito distinta da minha, para assim entender suas demandas. [...] Perceber as particularidades do grupo e de cada um, criar um vínculo, estabelecer uma relação de confiança e superar todas as dificuldades de ensinar uma língua nova, acredito, foi uma experiência de humanização.” (Aluna, 18 anos) "Trabalhei na ONG Vidas como voluntária. [...] Acho que nesse espaço vivenciei uma experiência de humanização ao conversar com pais que relatavam suas dificuldades como se precisassem desabafar." (Aluna, 19 anos)

"Certo dia, caminhava de volta para casa. Pela avenida onde passava, cruzei com um morador de rua, o qual pedia-me moedas pra almoçar no bom-prato. [...] pedi que me contasse sua história. Acabei conhecendo Wanderley, ex-detento do Carandiru, escritor e poeta anônimo, que me encantou com sua história durante a tarde daquele dia. [...] A história desse poeta tomou-me muitas noites de insônia e inspirou-me muito mais do que julgava saber." (Aluno, 21 anos) 
- Continuação Tabela 3 -

No atendimento em saúde

No Ambulatório Social FMUSP 2016
"Uma experiência de humanização que eu tive no início desse ano ocorreu durante a visita monitorada que eu e minha turma realizamos ao Instituto da Criança. [...] durante a visita a um dos quartos [...] a mãe de um garoto começou a conversar comigo e com um colega sobre sua história de vida. $\mathrm{O}$ fato de ela não nos conhecer, mas, mesmo assim, demonstrar tanta gratidão por estarmos ali me mostrou como atitudes simples como o ato de ler uma história, ao humanizar uma situação como aquela, também contribuem para melhorar o ambiente de tratamento [...]." (Aluna, 19 anos)

"Quando no Ensino Médio fiz uma visita ao GRAAC. [...] Tratar o paciente como um ser humano, entender do que necessita e o que os alegra. [...] nunca deve-se perder de vista que a interação interpessoal é muito importante em qualquer tratamento, e na vida." (Aluno, 19 anos)

"Semana de Recepção dos Calouros da Faculdade de Medicina da USP. [...] eu, particularmente, fui para o Instituto da Criança com o propósito de contar histórias. A expectativa pessoal era de encontrar crianças que interagissem comigo e com a história que fosse contar, mas quando cheguei no local fui designada a uma criança em estado pós cirúrgico e com aproximadamente 4 anos de idade. Ela não poderia responder a mim. [...] Decidi por iniciar a história, ainda que desconfortável e de forma inexperiente. [...] O olhar daquela criança foi tão forte que descobri que ela só precisava de alguém que lhe desse atenção [...] Descobri que a humanização é menos conceito e mais prática. (Aluna, 21 anos)

"No momento, a experiência de humanização mais marcante foi a nossa visita ao ambulatório na semana de recepção. Nós deveríamos perguntar aos pacientes o que eles entendiam por ser um bom médico. Quase unanimemente os pacientes ressaltaram a importância de escutar, ouvir, olhar no olho, dar atenção."

(Aluna, 19 anos)

"Talvez a grande, e recente, experiência de humanização, que tive o privilégio de viver, tenha sido a atividade do 'Ambulatório Social', durante a semana de recepção, realizada no HC. [...] Apesar de uma conversa de menos de uma hora, pude ver em seu semblante uma admiração pelo meu ingresso, a qual compartilhei, pela sua força. Foi uma vivência essencial, que ressaltou os princípios humanistas e de cuidado tão caros à prática médica.” (Aluno, 19 anos) 
- Continuação Tabela 3 -

\begin{tabular}{|c|c|c|}
\hline \multirow{3}{*}{ Humanização } & Na percepção/atenção/comunicação & $\begin{array}{l}\text { "Uma vez ao ir ao pronto-socorro tive que aguardar por mais uma hora até o atendimento. Ao entrar na } \\
\text { sala, os ânimos estavam bastante exaltados, mas, no entanto, o atendimento recebido foi de tal qualidade e } \\
\text { a atitude do médico tão calma e atenciosa, que todo o problema prévio foi facilmente contornado e } \\
\text { superado." (Aluno, } 18 \text { anos) } \\
\text { "Em uma típica consulta rotineira, durante o ano de vestibular, o médico, o qual constantemente eu } \\
\text { passava, percebeu o quão estressado/nervoso eu estava, sem eu comentar sequer sobre o assunto, em } \\
\text { seguida, ouviu-me e, inclusive, me orientou sobre algo que jamais esperaria ser assunto de uma consulta } \\
\text { médica rotineira: vestibular. Obviamente essa experiência foi muito positiva." (Aluno, } 18 \text { anos) }\end{array}$ \\
\hline & \multirow[b]{2}{*}{$\begin{array}{l}\text { Nas relações humanas } \\
\text { contemporâneas }\end{array}$} & $\begin{array}{l}\text { "Para mim, a maior experiência de humanização era ajudar os colegas no ensino médio. Possuindo } \\
\text { facilidade em diversas matérias, sempre estive disposto a ajudar colegas, independente da dificuldade que } \\
\text { tinham, ou do tempo que levaria. Era extremamente gratificante ouvir 'você me salvou' após uma prova } \\
\text { ou até mesmo em um vestibular. É essa sensação que quero ter como médico." (Aluno, } 18 \text { anos) }\end{array}$ \\
\hline & & $\begin{array}{l}\text { "Para mim, o 'simples' ato de construir um vínculo com alguém é uma experiência de humanização. } \\
\text { Receber a atenção, o suporte e o carinho dos pais é ser humanizado. Fazer novas amizades e manter } \\
\text { amizades antigas, ou seja, estabelecer relação de carinho, afeto e confiança com alguém antes totalmente } \\
\text { estranho a você, conhecer o outro e se apresentar ao outro, é uma experiência de humanização. Nesse } \\
\text { mesmo sentido, ser tratado com respeito e cordialidade por qualquer pessoa (uma pessoa no metrô, um } \\
\text { vendedor, um segurança, um professor...) é uma forma de humanização." (Aluno, } 20 \text { anos) }\end{array}$ \\
\hline
\end{tabular}

- Conclusão da Tabela 3 - 
5.2.4 Análise das respostas à questão 4: Quando você pensa em humanização na prática médica, qual a imagem ou modelo vêm à mente? Comente histórias que você leu, ouviu, assistiu nos diferentes meios impressos, virtuais, sonoros (música), visuais (filmes, peças de teatro, séries, documentários).

No que diz respeito às imagens e histórias que vêm à mente do estudante, pudemos elencar três categorias: Imagens, Iniciativas e Modelos.

Com relação às imagens, foram citados os filmes Patch Adams, Intocáveis, Tempo de Despertar, Gênio Indomável, A Vida é Bela e Sete Vidas. Os livros mencionados foram o Fausto (Goethe), Humano, demasiado humano (Nietzsche), A Morte de Ivan Ilitch (Tolstói), Estação Carandiru (Drauzio Varella), Presas que menstruam (Nana Queiroz), Extraordinário (RJ Palacio), O livro da maternagem (Dra. Relva) e A mente assombrada (Oliver Sacks). Foram citadas cenas do seriado Grey’s Anatomy, e, em contraposição à humanização, diversos estudantes mencionaram o Dr. House, do seriado americano House. Documentários também foram citados: Chernobyl Heart e O Renascimento do Parto.

$\mathrm{Na}$ categoria Iniciativas, os alunos mencionaram os Doutores da Alegria, o MadAlegria e os Hospitalhaços. Com relação a iniciativas médicas, são citados o Núcleo de Humanização do Hospital das Clínicas, a ONG Médicos sem Fronteiras, a Fundação Make a Wish, a Cruz Vermelha e os trabalhos realizados com populações ribeirinhas.

Os estudantes têm como principais modelos seus pais (quando médicos), tios (médicos), médicos que os atenderam. Citam ainda Ben Carson e Drauzio Varella. Além de modelos religiosos, Jesus e o bom samaritano da história bíblica.

As categorias e itens referentes à quarta questão, Imagem, Inciativas e Modelos, podem ser visualizados na figura 6 . 


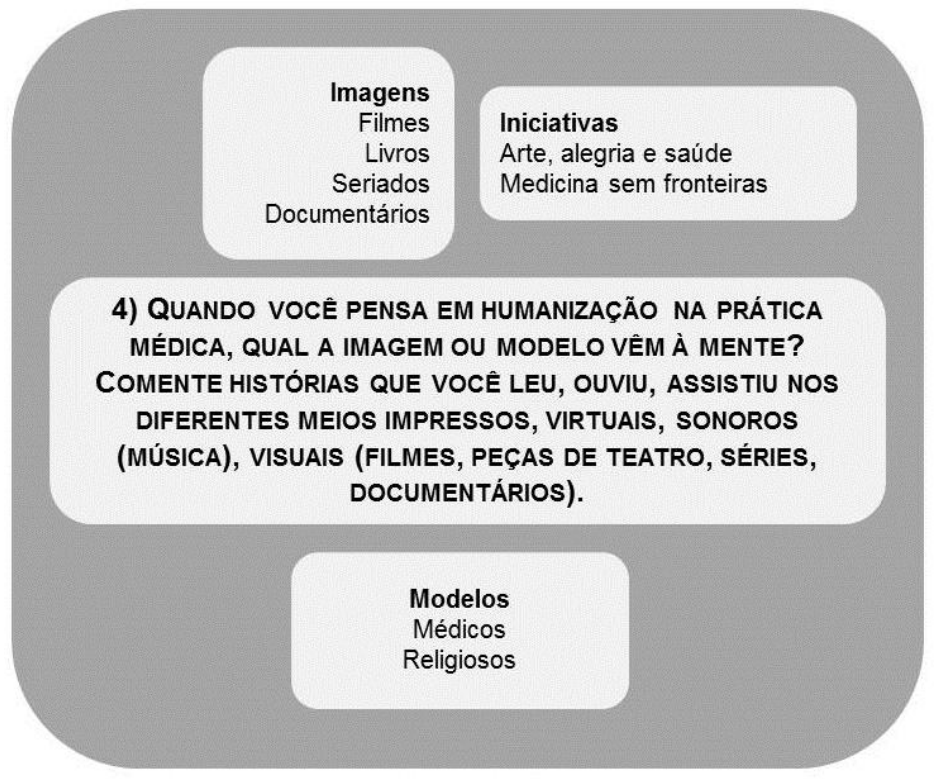

Figura 13: Categorias de análise referentes à questão 4: Quando você pensa em humanização na prática médica, qual a imagem ou modelo vêm à mente? Comente histórias que você leu, ouviu, assistiu nos diferentes meios impressos, virtuais, sonoros (música), visuais (filmes, peças de teatro, séries, documentários). 
Tabela 4: Análise qualitativa relativa à pergunta 4 - Quando você pensa em humanização na prática médica, qual a imagem ou modelo vêm à mente? Comente histórias que você leu, ouviu, assistiu nos diferentes meios impressos, virtuais, sonoros (música), visuais (filmes, peças de teatro, séries, documentários).

\begin{tabular}{|c|c|c|}
\hline Categorias & Itens & Exemplos de Discurso / Títulos, nomes e organizações citados \\
\hline \multirow{3}{*}{ Imagens } & Filmes & $\begin{array}{l}\text { "O modelo de humanização para mim, é o cuidador do paciente tetraplégico no filme 'Intocáveis', pois ele } \\
\text { não se limita às funções de dar banho e comida ao paciente, mas se mostra amigo, altruísta e dedicado, se } \\
\text { importando com aspectos além da condição física de saúde do homem.” (Aluna, } 20 \text { anos) } \\
\text { "A respeito de humanização na prática médica, um modelo expressivo que vem à minha mente é o } \\
\text { idealizado por Patch Adams. Seja no filme, seja nas palestras dadas por ele, a proposta transmitida de } \\
\text { priorizar o bem-estar em detrimento até mesmo de impedir o óbito é ideal. Isso porque muitas vezes a } \\
\text { busca pela cura pode desumanizar o cuidado, pois ela pode sacrificar o bem-estar do paciente." (Aluno, } 23 \\
\text { anos) }\end{array}$ \\
\hline & Livros & $\begin{array}{l}\text { "Livro: Humano, Demasiado Humano, de Friedrich Nietzsche em que o autor em parte do livro comenta } \\
\text { que a profissão médica é um exemplo de humanização. Na qual, o médico deve ser para o paciente uma } \\
\text { forma de amparo, não só fisicamente mas também emocionalmente.” (Aluna, } 19 \text { anos) } \\
\text { “... o livro 'Estação Carandiru' de Drauzio Varella trata de um processo de conhecimento do universo do } \\
\text { sistema carcerário. Do livro, é possível perceber uma densidade psicológica de vários dos indivíduos } \\
\text { inclusive a presença de um código de conduta dentre os presos. Assim, o autor estimula a humanização na } \\
\text { prática médica, pois, até num ambiente marginalizado, há uma alma por trás de cada pessoa.” (Aluno, } 21 \\
\text { anos) }\end{array}$ \\
\hline & Seriados & $\begin{array}{l}\text { "Na série 'House' há em muitos episódios momentos em que o personagem principal age de forma rude } \\
\text { com o paciente. Isso contraria a Humanização. Todavia, o melhor amigo de House, Dr. Wilson, é um } \\
\text { exemplo de médico humanista, que sempre trata e cuida dos seus pacientes com atenção, paciência e } \\
\text { tolerância." (Aluna, } 18 \text { anos) } \\
\text { "Assisto à série 'Gray's Anatomy' e nela já vi vários casos de humanização, nos quais os médicos } \\
\text { aproximam-se dos pacientes fornecendo-lhes conforto, ajuda e um tratamento mais eficiente possível. Em } \\
\text { vários desses casos, me senti inspirada e ainda mais ansiosa para adentrar no mundo da medicina." (Aluna, } \\
19 \text { anos) }\end{array}$ \\
\hline
\end{tabular}


- Continuação Tabela 4 -

\begin{tabular}{|c|c|c|}
\hline Imagens & Documentários & $\begin{array}{l}\text { "No documentário 'O Renascimento do Parto', além de problematizar a questão do parto, mostra uma } \\
\text { maneira humanizada de dar à luz a uma nova vida, seja em casa, no hospital, parto normal ou cesariano de } \\
\text { maneira a tornar esse momento especial para a mãe, ao invés de traumatizante como é comum ocorrer." } \\
\text { (Aluna, } 22 \text { anos) } \\
\text { "Quando eu penso em humanização na prática médica me recordo do documentário 'Chernobyl Heart', o } \\
\text { qual mostrou o atendimento médico em uma região da Bielorrússia. Nesse atendimento, os profissionais } \\
\text { da saúde se colocaram tratando-os de forma acolhedora e empática. Além disso, questionaram-lhes sobre } \\
\text { seus sonhos e sobre características de suas rotinas, dando voz àquelas pessoas que já haviam sofrido } \\
\text { tanto." (Aluno, } 19 \text { anos) }\end{array}$ \\
\hline & Arte, alegria e saúde & $\begin{array}{l}\text { "Uma das práticas médicas que me vêm à mente, relacionada com a humanização são os Hospitalhaços. } \\
\text { Nessa prática vejo que o paciente não é tratado apenas como mais um no hospital, assim, o projeto cuida } \\
\text { do social e do mental do paciente no processo de humanização." (Aluna, } 20 \text { anos) } \\
\text { "Tomo como modelo de humanização o Projeto Doutores da Alegria e a ação do doutor Patch Adams [...]. } \\
\text { Embora a humanização não necessite de um tom cômico, a atenção é a minha referência de atendimento } \\
\text { humanizado." (Aluno, } 18 \text { anos) }\end{array}$ \\
\hline niciativas & Medicina sem fronteiras & $\begin{array}{l}\text { "O primeiro modelo que me vem à mente é a ONG Médicos Sem Fronteiras, pois admiro muito seu } \\
\text { trabalho. Esses médicos partem para as regiões mais carentes, muitas vezes locais em guerras que } \\
\text { apresentam perigo, com o único objetivo de ajudar os outros. Assim, eles percebem a dimensão social e a } \\
\text { necessidade dessas pessoas e fazem o possível para melhorar as condições delas." (Aluna, } 19 \text { anos) } \\
\text { "A história que mais me impressionou foi o trabalho realizado pelo Núcleo de Humanização do Hospital } \\
\text { das Clínicas, um departamento exemplar na sua área de atuação. Esse núcleo trabalha a ambiência do leito } \\
\text { infantil, dando vida ao local e mantendo aberta uma brinquedoteca aos pacientes; além disso, disponibiliza } \\
\text { vídeos de desenhos durante exames para acalmar as crianças e fazê-las mais confortáveis no ambiente } \\
\text { hospitalar." (Aluno, } 17 \text { anos) } \\
\text { "Quando penso na prática médica humanizada, vem à mente os médicos que vão até a África, cuidar das } \\
\text { pessoas de regiões miseráveis, colocando em risco a própria vida, para ajudar o próximo, independente } \\
\text { onde seja." (Aluno, } 20 \text { anos) }\end{array}$ \\
\hline
\end{tabular}


- Continuação Tabela 4 -

\begin{tabular}{|c|c|c|}
\hline \multirow{5}{*}{ Modelos } & \multirow{3}{*}{ Médicos } & $\begin{array}{l}\text { "Quando penso em humanização me vem à mente o doutor Drauzio Varella, que tem vários livros sobre a } \\
\text { experiência dele na área médica e cita casos que o marcaram. Para mim os relatos dele são realmente } \\
\text { impactantes pois mostram como o cuidado com o paciente faz a diferença e como a profissão médica vai } \\
\text { além do simples conhecimento técnico, exigindo muito do emocional do médico." (Aluna, } 25 \text { anos) }\end{array}$ \\
\hline & & $\begin{array}{l}\text { "Me vem à mente a imagem de uma médica que acompanhei em um trabalho voluntário no interior de São } \\
\text { Paulo em um quilombo. Era uma pediatra cujas consultas eram realizadas de modo tão carinhoso e } \\
\text { atencioso com todos os envolvidos (pais, pacientes, irmãos e até mesmo alunos que assistiam e queriam } \\
\text { participar) que me deixaram encantada e ansiosa com a profissão médica." (Aluna, } 19 \text { anos) }\end{array}$ \\
\hline & & $\begin{array}{l}\text { "Apesar de ter ambos os pais médicos, sempre tive como modelo o meu pai. Em inúmeros jantares ele me } \\
\text { contava sobre casos clínicos e em como muitos deles, a causa do problema nem sempre é físico. Casos de } \\
\text { ansiedade, de depressão e medo, e o modo que ele relatava lidar com isso, através de conversa e amizade, } \\
\text { sempre me serviu de exemplo de humanização e bom profissional." (Aluno, } 18 \text { anos) }\end{array}$ \\
\hline & & $\begin{array}{l}\text { "Como imagem e modelo, lembro-me da história do bom samaritano, que acolhe e ajuda uma pessoa de } \\
\text { uma tribo rival." (Aluno, } 26 \text { anos) }\end{array}$ \\
\hline & Religiosos & $\begin{array}{l}\text { "Jesus. Relacionamento interpessoal sem julgamentos prévios. Alto conhecimento intrapessoal. } \\
\text { Habilidade de comunicar-se de forma carinhosa, afetiva e eficaz. Toque. Todas essas características } \\
\text { levam-me a crer que Jesus Cristo, como retratado em uma miríade de momentos bíblicos relacionados a } \\
\text { fenômenos de cura, é um exemplo de humanização." (Aluno, } 17 \text { anos) }\end{array}$ \\
\hline
\end{tabular}

- Conclusão da Tabela 4 - 


\section{DISCUSSÃo}

As narrativas têm como função remodelar, representar, estruturar em linguagem e texto a ação humana. São compostas e preenchidas por experiências, valores, maneiras de habitar, ver e pensar o mundo, ou seja, por aspectos socioculturais. Trazidas as experiências e ações humanas para a narrativa, a partir de sua leitura, então a interpretação pode explorar as condições sociais, econômicas, culturais presentes na produção do texto. Pode também a interpretação procurar no texto a capacidade de projetar-se para fora de si mesmo, atuando no mundo da ação (Ricoeur, 1986, p. 42-43). Uma vez articuladas em signos, regras e normas que dão direção à vida, as ações e as experiências podem, então, ser organizadas em texto, ou seja, podem ser narradas (Ricoeur, 2012, p. 100-101).

Desta forma, os fragmentos de histórias vividas no cotidiano (ações e experiências) construíram as narrativas dos estudantes, expondo uma pré-história da história narrada, ou seja, um contexto, um pano de fundo no qual a história está inserida e enredada.

Esse pano de fundo é feito da "imbricação viva" de todas as histórias vividas umas nas outras. Portanto, é preciso que as histórias contadas possam "emergir" (auftauchen) desse pano de fundo. Com essa emergência, o sujeito implicado também emerge. Pode-se então dizer: "A história responde pelo homem" (die Geschichte steht für den Mann). [...] A consequência principal dessa análise existencial do homem como "ser enredado em histórias" é que narrar é um processo secundário, o do "tornar-se conhecido da história" (das Bekanntwerden der Geschichte). [...] Narrar, acompanhar, entender histórias é apenas a "continuação" dessas histórias não ditas. (Ricoeur, 2012, p. 129) ${ }^{7}$

Conforme Ricoeur (2012, p. 98), interação, circunstância e desfecho compõem a rede conceitual da narrativa. Assim, a interação (ação dos estudantes com outras pessoas) em certas circunstâncias (de adoecimento e convivência com a área da saúde) e o consequente desfecho (feliz ou infeliz) possibilitaram a produção de narrativas carregadas de significados que expressam condições do mundo em que estão inseridos.

\footnotetext{
${ }^{7}$ As palavras e frases entre aspas e parêntesis nesta citação são do filósofo Wilhelm Schapp (1884-1965) em seu livro Envolvido em Histórias - In Geschichten verstrickt [1976], citadas por Paul Ricoeur, 2012.
} 
É nesse contexto que os estudantes narram suas experiências com a humanização ou a desumanização. A experiência tem a capacidade de vincular, na mente da pessoa que experimenta, o mundo exterior e suas reflexões interiores. Carrega em si, por isso, a potência de transformação de si mesmo e do ambiente que a cerca. Atitudes como dar atenção às pessoas, respeitá-las, valorizar seus sentimentos de medo e insegurança, interessar-se pela vida e pela história das pessoas e construir com elas vínculos afetivos e mais humanos são realçados nas narrativas dos alunos. Foram narradas diversas experiências de desumanização no sistema de saúde brasileiro - público e privado. Os alunos identificam e desaprovam o descaso dos médicos com a dor, com os medos e em relação às histórias pessoais dos pacientes, criticam os erros diagnósticos e o domínio e a interferência da tecnologia (computadores e celulares) no momento do encontro entre médico e paciente.

Tais preocupações relatadas pelos alunos, de forma direta ou indireta, vêm ao encontro de algumas premissas a respeito do tema da humanização expostas nas primeiras páginas deste estudo, a serem retomadas e discutidas agora.

Primeiramente, um dos objetivos deste estudo foi detectar valores, perspectivas e visões de mundo construídos pelos estudantes antes mesmo de entrar na faculdade. Nesse sentido, os estudantes apresentam como algumas de suas perspectivas e visões de mundo o interesse por cuidar da saúde e do bem-estar das pessoas e a motivação por se relacionar com as pessoas, perspectivas que podem ser observadas nos seguintes trechos de narrativas:

O fascínio pelos meus médicos em consultas, tratamentos e cirurgias foi fundamental para despertar o interesse pela medicina. $O$ cuidado e o sentimento de confiança eram mútuos e demonstravam a beleza da profissão. Justamente o fato de ter sido um paciente com cuidadores competentes abriu uma porta pra essa escolha. (Aluno, 17 anos)

Naquele caso, eu era seu acompanhante e num momento de extrema necessidade vi o profissional médico atuando de forma além da prática técnica, no sentido de amparar o paciente numa situação emergencial. ... Decidi pela carreira médica a fim de conseguir fornecer àquele que necessita de cuidados uma atenção que vai além da técnica, abarcando aspectos mais humanísticos como o descompasso psicológico numa situação tão delicada. (Aluno, 20 anos)

Hoje, penso em fazer medicina porque amo a área de humanas e também me relacionar com pessoas, mas também tenho muito 
interesse por pesquisas na área científica (gosto muito de química e de biologia). (Aluna, 18 anos)

Além dessas perspectivas, as narrativas apresentadas como respostas a essa pesquisa demonstraram que os estudantes estabelecem relações entre humanização e cultura. Para eles, compreender o ser humano dentro de um contexto social, cultural, econômico, familiar proporciona a realização de um atendimento humanizado. Os estudantes dizem que é necessário ouvir o paciente, saber um pouco de sua história, de sua cultura, seus hábitos e se dispor a auxiliar o paciente não apenas com um tratamento clínico, hospitalar e medicamentoso, mas também se propor a ajudar as pessoas num âmbito psicológico. Demonstram o interesse por valores humanísticos (como a consideração de aspectos culturais, históricos e sensíveis dos pacientes para melhor atende-lo), conferem importância às relações humanas, e ao compromisso com a felicidade humana. Os dois seguintes trechos de narrativas demonstram esse interesse:

Humanizar é ver além da dimensão técnica, observando que por trás de uma doença ou um diagnóstico existe também um ser humano, imerso em suas questões étnicas, socioeconômicas e culturais. (Aluna, 18 anos)

Reconhecer o outro como humano, um ser com história, carga emocional e contexto social. Mais do que apenas reconhecer, é lidar com o fato de que todas essas implicações interferem na saúde e na qualidade de vida da outra pessoa. É saber, de maneira prática e concreta, como lidar com essa pessoa de forma a não negligenciar todo o seu entorno. (Aluna, 18 anos)

Já as referências à importância da felicidade humana foram feitas quando questionados sobre os seus modelos:

No filme Patch Adams, o modelo que o protagonista apresenta de humanização é incrível, o jeito como ele tenta mostrar a todos que há felicidades na vida e como cada paciente é único e deve ser tratado com singularidade me faz pensar que é assim que um médico deve ser. (Aluna, 22 anos)

Livros que me vêm à mente: Fausto, de Goethe, A morte de Ivan Ilitch, de Tolstói. Não são necessariamente livros com personagens exemplo, mas que contribuem para reflexão sobre humanização na medicina ou para se refletir sobre o que é sucesso/felicidade profissional. (Aluno, 28 anos) 
A série Grey's Anatomy mostra em várias cenas a experiência de humanização, como quando os médicos se envolvem com o paciente e lutam pelo seu bem-estar e pela sua felicidade. (Aluno, 17 anos)

A dialogar com essa perspectiva dos estudantes, um aspecto que tem impactado fortemente a cultura ocidental contemporânea, na qual estes estudantes estão inseridos, desde o século XX é o desenvolvimento científico e tecnológico. Os efeitos dos avanços técnico-científicos podem ser vistos de forma evidente na medicina moderna, que separa o que é físico, aquilo que pode ser visto, apalpado e medido, do que é mental psicológico, social ou cultural.

Essa medicina privilegia os números e os consensos referentes à normalidade e à anormalidade e baseia-se nos exames de imagem e nas tecnologias diagnósticas, médicos (e, em consequência, a própria educação médica) têm dado mais importância à racionalidade científica do que às dimensões sociais, culturais e psicológicas que envolvem o paciente e sua compreensão da doença (Helman, 2009).

Acontece que os valores humanísticos, inseridos nas dimensões sociais, culturais e psicológicas, os quais motivam a busca por uma vida boa (individual e em comunidade), foram distanciados da prática médica devido à supervalorização dos avanços técnico-científicos. Fato que transformou rapidamente as culturas ocidentais, nas quais os valores e os costumes foram grandemente alterados, porque a velocidade da vida, o dilúvio das imagens e a coação tecnológica se tornaram parte inerente do cotidiano das pessoas.

Podemos dizer, assim, que a tecnologia permeia, hoje, todos estes aspectos da cultura. Estamos imersos em uma cultura de tecnologia. Tudo passa pela imagem, pela velocidade, pela internet, e por todas as tecnologias que visam "facilitar" o andamento da vida humana e o funcionamento da sociedade, e que pode ter como resultado, o crescimento do individualismo. A preocupação com o outro destituída de egoísmo e intolerância e a necessidade de lidar com o paciente baseando-se em atitudes que vão além da técnica e do conhecimento científico podem ser observadas nesses trechos de discurso:

Humanizar é captar tudo aquilo que não está explícito, é perceber as dores e angústias mais escondidas e ter a capacidade de lidar com elas. (Aluno, 21 anos) 
Humanizar é valorizar, cultivar e incentivar a manifestação desses sentimentos tipicamente humanos, tais como a empatia, o amor ao outro e, sobretudo, o sentimento de pertencimento a um todo chamado humanidade que precisa constantemente do altruísmo para existir e evoluir. (Aluno, 18 anos)

Tratar o próximo com respeito, atenção e dedicação, considerando-o como um ser humano que possui suas necessidades e problemas, que podem ser sanados ou aliviados, e não o considerando como um simples objeto de estudo sem levar em conta seus sentimentos, sensações, medos, angústias e tudo o mais que faz parte do ser humano. (Aluno, 26 anos)

Quando penso em humanização me vem à mente o doutor Drauzio Varella, que tem vários livros sobre a experiência dele na área médica e cita casos que o marcaram. Para mim os relatos dele são realmente impactantes pois mostram como o cuidado com o paciente faz a diferença e como a profissão médica vai além do simples conhecimento técnico, exigindo muito do emocional do médico. (Aluna, 25 anos)

Neste ponto, vale salientar que dentro da cultura ocidental encontra-se uma diversidade imensa de singularidades em cada continente, em cada país, em cada estado e cidade. Portanto, o que é considerado humanização para os estudantes de medicina brasileiro pode ser diverso do que pensam os europeus, ou os norte-americanos.

Nas suas narrativas, os estudantes de nosso país demonstram compreender que as construções sociais e culturais elaboradas na vida pessoal de cada ser humano, neste caso, médicos e pacientes, interferem nessa relação, e que um olhar atento para o mundo em que estão inseridas as outras pessoas se constitui em um caminho para se construir um encontro humanizado, como expressaram estes dois estudantes:

Humanizar é enxergar o outro. É saber, ou querer saber, do outrosua história, seus desejos, sonhos, medos, angústias. ... É tratar, como pessoa, o outro, considerando suas "bagagens" histórica, cultural, social. (Aluno, 20 anos)

Entender que cada paciente que entra no hospital ou no consultório é uma pessoa diferente, com uma história, com medos, com vontades e, portanto, cada consulta é distinta. Humanizar é compreender que o paciente está confiando seu corpo ao profissional da saúde, o bem mais importante que ele tem, e é preciso dar valor a isso. Humanizar é tratar com a mesma significância que o paciente o breve momento do atendimento. (Aluno, 19 anos) 
Outro objetivo deste estudo foi estabelecer relações de convergência ou de divergência entre essas perspectivas e valores dos estudantes com aqueles da sociedade contemporânea. A respeito desse aspecto, os estudantes apresentam uma postura muito interessante, que, ao invés de denotar conformismo e aceitação de uma dada realidade insatisfatória para a área da saúde, expressa a vontade de interferir na realidade da pólis, como quis Ayres (2005), de forma profissional e, por vezes política, como se pode analisar nos dois exemplos de discurso seguintes:

A medicina foi a [profissão] que mais me atraiu. Não só pelo belo trabalho que um médico faz, mas também pela ótima sensação de que eu poderia contribuir para melhorar o Brasil. ... com a medicina, eu senti que conseguiria exercer a profissão sem duvidar do potencial da prática médica em melhorar a sociedade. (Aluna, 19 anos)

A escolha da profissão médica se deve ao meu interesse em ajudar o próximo e contribuir para certa mudança social. Na medicina posso encontrar não só aspectos biológicos como também aspectos mentais e sociais, e esses dois últimos foram importantes na minha decisão. Durante meu ensino médio, tive contato com discussões reflexivas e questionadoras, o que me levou a buscar essa essência na profissão médica. (Aluno, 18 anos)

... ao me deparar com as precárias condições de saúde do nosso país, me senti motivada a tentar mudar essa realidade e prover um atendimento digno às pessoas. (Aluna, 20 anos)

Outra afirmação feita em nossa Introdução diz que humanizar está relacionado a um âmbito filosófico e cultural, os quais precedem os comportamentos e dirigem as escolhas humanas. Mais uma vez, os discursos dos alunos corroboram com nossas afirmativas, mostrando que a singularidade do ser humano precisa ser valorizada, bem como as relações interpessoais devem ser alimentadas e os laços humanos, fortalecidos. Vejamos:

Humanizar é tratar as pessoas como pessoas. Cada um tem seus anseios, preocupações, medos e realidades. É difícil enxergar o mundo de outra perspectiva que não a de nossos olhos, mas é uma experiência fascinante. Quando no metrô ou na calçada, enxergar que cada uma daquelas pessoas vivem experiências, amou, foi amado, brigou, chorou e tem uma história completamente única. ... Humanizar é entender que todos merecem a atenção e os cuidados melhores, visto que são plenos em sua singularidade. (Aluno, 19 anos) 
Humanizar é o ato de conciliar o saber técnico à proximidade com o paciente. Os avanços tecnológicos permitem melhores oportunidades de diagnóstico, tratamento e prevenção de doenças. Contudo, é necessário que se leve em consideração o fato de que o paciente é um ser humano com dúvidas, sentimentos, problemas, angústias. Nesse sentido, é papel do médico proporcionar, da melhor forma possível, um bom atendimento, seja no sentido técnico, seja no entendimento dos anseios mentais e sociais do ser humano que pede ajuda. (Aluna, 19 anos)

Ainda neste caminho que visa a importância de se compreender o outro através da observação e valorização de seu contexto histórico, social e cultural, Arno Kumagai (2014) também reforça a característica humanista da profissão médica: "a medicina é um tipo de humanismo aplicado, isto é, a aplicação da ciência no reconhecimento de valores humanos e ao serviço das necessidades humanas". Assim é entendida pelos estudantes a sua futura profissão. Os valores humanos precisam estar presentes na relação entre médico e paciente, a fim de se chegar a um resultado melhor de cura, tratamento ou de atendimento paliativo. Os discursos seguintes expressam essa perspectiva:

Com aproximadamente 14 anos comecei a frequentar atividades voluntárias que me colocaram em contato com outras realidades realidades distantes da minha, e isso foi um motivador para que eu escolhesse a medicina, pois eu entendi que através dessa profissão eu teria a oportunidade de transformar a vida e a realidade de outras pessoas. (Aluna, 20 anos)

O interesse pelo conteúdo [biológicas] somou-se à possibilidade de cumprir um papel social que a profissão fornece e cuidar da saúde, direito fundamental a todos da população. (Aluna, 19 anos)

Podemos inferir dessas narrativas que o estudante de medicina compreende a humanização como cuidado humanístico para com os pacientes. Valorizam questões culturais, socioeconômicas e relacionadas à história de vida do paciente. A felicidade é mencionada como possibilidade dentro de um entendimento das pessoas como portadoras de medos, sonhos, angústias, histórias, quando estes aspectos são considerados, avaliados e inseridos na relação entre médico e paciente. 


\subsection{Perfil e contexto dos estudantes respondentes}

As respostas ao questionário sociodemográfico trazem aspectos culturais e sociais ligados à profissão dos pais dos estudantes que optaram pela profissão médica. Os dados do presente estudo informam que $74 \%$ dos pais e $57 \%$ das mães dos estudantes exercem profissões que não estão ligadas à área da saúde, não havendo relação direta, para a maioria dos estudantes, entre a profissão dos pais e a sua própria escolha profissional. Observamos que $15 \%$ dos pais são médicos e $8 \%$ das mães são médicas. Enquanto $2 \%$ dos pais e $14 \%$ das mães são profissionais de diferentes áreas da saúde. Um dado interessante é que o número de pais e mães de estudantes homens, profissionais da área médica ou outras áreas da saúde é maior que o número de pais e mães de estudantes mulheres, profissionais da área médica ou outras áreas da saúde: enquanto $36 \%$ dos estudantes homens possuem pais médicos ou da área de saúde, 20,8\% das estudantes mulheres têm pais médicos ou da área da saúde.

A realidade do mundo das mulheres que vem se delineando desde os movimentos sociais das décadas de 1960 e 1970 apresenta um leque progressivamente maior de opções e possibilidades de vida diferentes daquela vida feminina anteriormente centrada na família e no lar. A mulher vem se mostrando, nesta conjuntura, aberta e ávida a aproveitar da melhor forma esta nova configuração de um mundo que lhe permite escolher seus próprios caminhos, conforme seus próprios desejos e sonhos. Neste sentido é que se coloca o fenômeno de feminização da medicina. Diversos estudos demonstram a maioria de estudantes de medicina do sexo feminino (Kilminster at al., 2007; McKinstry, 2008)

As transformações sociais inspiram novas maneiras pelas quais os jovens escolhem seus destinos profissionais, ocupações, relações econômicas e os caminhos que os levarão a alcançar os padrões e qualidade de vida que almejam. As escolhas destes jovens, atualmente, estão bastante - mas não totalmente - desvinculadas das expectativas, desejos, sonhos ou influências dos pais. O jovem tem a liberdade e o estímulo para identificar suas inclinações e para buscar, até mesmo com a ajuda dos pais, novas experiências e formas de manifestar seus interesses e expressar suas tendências e seus pensamentos; ele pode tentar, errar, acertar, seguir e voltar. As trajetórias no mundo pós-moderno não são fixas, rígidas ou deterministas. São fluidas, 
instáveis, variáveis, provisórias, sem contornos definidos, incertas e abertas (Bauman, 2012).

Nesse contexto social e econômico contemporâneo, o estudante de medicina participante do presente estudo cresce, é educado, se relaciona, reconhece suas inclinações e habilidades, percebe seus desejos e constrói seus sonhos. Essas dimensões, raízes e esses valores se revelaram em suas narrativas, permitindo tal construção do perfil deste grupo de estudantes.

O presente estudo apresenta como ponto forte seu desenho inovador, à medida que utiliza narrativa como forma de coleta de dados. Além disto, permitiu aos participantes um momento de reflexão sobre sua própria trajetória e escolha profissional. Outro ponto forte foi tratar de um tema atual e pertinente à formação médica. O ponto fraco está na escolha de uma única coleta para este momento do estudo, o que para um estudo exploratório é possível e defensável. Uma possibilidade de reparar tal fraqueza do estudo seria revisitar estes alunos em seus anos finais do curso de Medicina. Neste momento futuro, seria observado como se deu a sedimentação ou o abandono das percepções e valores iniciais de humanização relativas ao cuidado e à relação médico-paciente, bem como, poderiam ser analisadas as influências e os modelos presentes na relação professor-aluno. 


\section{CONClusões}

A análise dos dados socioemográficos e das narrativas dos estudantes participantes deste estudo nos permitem afirmar que: 1 - possuem valores morais e sociais compatíveis com os aspectos considerados por eles como humanização, independente de classe social, idade e religiosidade; 2 - valorizam as relações familiares, expressando influências e modelos vindos de pais e parentes; e 3 preocupam-se com o futuro, tanto financeiro quanto profissional.

No sentido de influência na escolha profissional, expressam gratidão pelas boas experiências anteriores com profissionais médicos, admiração pela profissão médica e o interesse por reproduzir bons modelos. Sua visão de humanização também foi construída a partir do ambiente familiar, no qual encontraram modelos dos próprios pais ou de outros parentes devido à sua dedicação e profissionalismo na atuação com os pacientes.

Nas narrativas, os estudantes se colocam ora como agentes, ora como vítimas das situações de humanização e desumanização que descreveram. Ao apresentarem suas ações e seus padecimentos, reconstroem o tempo em que vivenciaram situações marcantes e assim ordenam suas experiências. As experiências pessoais com a humanização e ou a desumanização demonstraram ser fontes para a construção das narrativas e para a concepção a respeito de humanização. Dessa forma, suas respostas às questões propostas nos possibilitaram atingir o objetivo do estudo: compreender o significado de humanização para estes estudantes.

Retomando as perspectivas deste estudo, entende-se que o estudante está inserido no contexto do ambiente de ensino da Faculdade de Medicina da Universidade de São Paulo, que, por sua vez, encontra-se inserido num contexto sociocultural contemporâneo. Uma contemporaneidade que apresenta conflitos sociais e econômicos próprios do estágio atual de desenvolvimento do nosso país e do mundo. As narrativas apresentam expectativas dos estudantes por uma sociedade mais humana, com a presença de valores como respeito, solidariedade e compaixão, revelando que os aspectos éticos, culturais e profissionais da humanização estão interligados. Eles falam também da possibilidade de transformação da realidade a partir do seu "fazer médico" 
ou "oferecer cuidado" melhorar a vida de outras pessoas. Os valores e as tendências presentes nessa ideia e na predisposição dos estudantes para tal podem ser vistos como uma resposta a alguns dos males contemporâneos, como as crises que envolvem o campo da saúde e as desigualdades sociais extremas.

No contexto das narrativas, o significado de humanização para o estudante de medicina está relacionado, o tempo todo, ao "fazer" e ao "como fazer" do médico, que precisa ser dirigido pelas dimensões ética, cultural e profissional.

Neste sentido, no decorrer da pesquisa, o objetivo de compreender o significado de humanização para estudantes de primeiro ano de Medicina foi alcançado e pode ser sintetizado na resposta de uma futura médica de 21 anos: "Descobri que a humanização é menos conceito e mais prática".

Os estudantes ingressantes que participaram deste estudo entendem que o saber técnico e científico precisa estar acompanhado de um comportamento ético, que vise o desenvolvimento humano de ambos, médico e paciente. E ainda que esta relação seja pautada em valores como o compromisso com uma vida boa e a felicidade do outro.

A presente pesquisa demonstra que, não obstante as tendências sociais, há um círculo de pessoas determinadas, que podem estabelecer novas práticas de cuidado, e que têm com condições de irradiar suas perspectivas profissionais e pessoais relacionadas à humanização. Finalmente, a pergunta que se coloca ao final deste estudo é em que medida esse sentido de humanização para o estudante de medicina de primeiro ano será transformada, mantida ou neutralizada nos anos de sua formação médica. 
9. ANEXOS 


\section{ANEXOA \\ Caderno de Respostas}

\section{Termo de Consentimento Livre e Esclarecido}

Projeto de Pesquisa

"Medicina Narrativa: o significado de humanização para estudantes de Medicina"

Este projeto será desenvolvido junto aos estudantes de medicina matriculados na Faculdade de Medicina da USP, e tem por objetivo compreender o significado de humanização para estudantes de medicina. Para alcançar este objetivo, será realizado previamente um estudo a respeito da sociedade contemporânea, com a finalidade de compreender em que contexto social o estudante está inserido. Será estudado também o contexto educacional do estudante. Posteriormente, será feita a pesquisa com o universo de alunos matriculados no $1^{\circ}$ e $2^{\circ}$ anos, no primeiro bimestre de 2015 .

No dia da pesquisa, primeiramente será entregue este termo para que o aluno que queira participar assine. Em seguida, será entregue o Questionário Sociodemográfico. Após respondê-lo, os alunos receberão os excertos de textos a serem lidos. E, por fim, serão entregues as questões a serem respondidas. O tempo previsto para a realização da pesquisa é de aproximadamente 65 minutos.

Esta pesquisa será realizada por Luciana de Almeida Tavares, do curso de Ciências Médicas da FMUSP, sob orientação da Professora Patricia Tempski (FMUSP).

$\mathrm{Eu}$,

$\mathrm{RG}$ abaixo assinado (a), concordo em participar desse estudo acerca do significado de humanização para estudantes de medicina, estando ciente de que:

1. Este projeto não implicará na utilização de métodos invasivos e não haverá risco à integridade física e mental. 
2. As informações (respostas) serão coletadas por escrito.

3. Fica garantido o direito de confidencialidade dos participantes.

4. O participante pode retirar seu consentimento e se abster de responder às questões quando desejar.

5. Fica garantido o acesso aos resultados do estudo, quando solicitado.

6. Não haverá nenhuma forma de pagamento aos participantes.

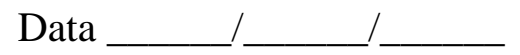

Assinatura do estudante

Pesquisadora - Luciana de Almeida Tavares - lu-a-tavares@ hotmail.com 
2. Questionário Sociodemográfico

\begin{tabular}{|c|c|}
\hline Sexo & Idade \\
\hline \multicolumn{2}{|l|}{ Profissão do pai: } \\
\hline \multicolumn{2}{|l|}{ Profissão da mãe: } \\
\hline \multicolumn{2}{|l|}{ Natural de: } \\
\hline Religião: & Praticante: $\operatorname{sim}($ ) não ( ) \\
\hline \multicolumn{2}{|l|}{ Renda familiar em torno de: } \\
\hline $\begin{array}{l}\text { Cursou Ensino Fundamenta } \\
\text { Escola Pública ( ) Escol }\end{array}$ & ) Ambas ( ) \\
\hline Cursou Ensino Médio: & Ambas ( ) \\
\hline Bolsista: sim ( ) não ( ) & Cotista: $\operatorname{sim}($ ) não ( ) \\
\hline
\end{tabular}




\section{Entrevista Semiestruturada}

1) Qual experiência ou motivos levaram você a escolher a profissão médica? Sua história é importante, utilize quantas linhas forem necessárias. 
2) Humanizar é ... Complete com suas palavras. 
3) Narre uma experiência de humanização ou desumanização vivida por você, utilizando quantas linhas forem necessárias. 
4) Quando você pensa em humanização na prática médica, qual a imagem ou modelo vêm à mente? Comente histórias que você leu, ouviu, assistiu nos diferentes meios impressos, virtuais, sonoros (música), visuais (filmes, peças de teatro, séries, documentários). 


\begin{abstract}
ANEXO B
Conjunto completo de discursos referentes à pergunta 1 - Qual experiência ou motivos levaram você a escolher a profissão médica? Sua história é importante, utilize quantas linhas forem necessárias.
\end{abstract}

\title{
Experiências Pessoais
}

\section{Adoecimento próprio}

"Levando em consideração as influências que tive, elas partiram de experiências do dia a dia, quando fui muito bem atendida por profissionais da saúde, mas principalmente pelos maus atendimentos que eu e minha família recebemos. Essas experiências ruins, em que o doutor sequer me cumprimentou ou me deixou falar o que eu estava sentindo ou me permitiu questionar os diagnósticos e exames tiveram maior peso em minha decisão porque me mostraram claramente a profissional, e, principalmente, a PESSOA que eu não quero ser.” (Aluna, 19 anos)

"Após tais acontecimentos [tentativa de suicídio da irmã e surto psicótico do pai], o interesse pela medicina se intensificou e o medo da impotência perante crises tanto da minha irmã quanto do meu pai; e a curiosidade e vontade de entender a doença deles [bipolaridade] e ajudar na medida do possível; foi o ponto final pela decisão da carreira." (Aluna, 19 anos)

"Quando eu era pequena, sempre ficava doente devido a problemas respiratórios. Quando isso ocorria, era levada para uma médica que me acompanhou durante toda a minha infância. Essa profissional sempre foi muito atenciosa, o que me levou a buscar a área da medicina para passar para outras pessoas um pouco do acolhimento que eu tive durante esses anos." (Aluna, 20 anos)

“... a dificuldade de encontrar um pediatra e obstetra que correspondesse ao que eu procurava e que se mostrasse atualizado, principalmente no quesito de humanização, me levaram à decisão de ser médica. Principalmente quando eu vi como os cuidados e orientações corretos podem influenciar positivamente e a longo prazo na vida do ser humano." (Aluna, 21 anos)

"Também fui muito influenciada por alguns médicos que cuidaram da minha saúde com carinho ao longo da minha vida, e quero fazer o mesmo com os meus futuros pacientes." (Aluna, 18 anos)

"Também percebi que sem a saúde eles [os dois avôs internados] não pareciam sequer a mesma pessoa de antes e vi o quanto os médicos trabalham e se esforçam para garantir o bem-estar dos pacientes." (Aluna, 18 anos)

"Tal experiência [pai com tumor maligno no cérebro], bem como a vivência em hospitais, me fez criar uma paixão pelo cuidar e entender obtidos na profissão médica, resultando na escolha de seguir essa profissão.” (Aluna, 18 anos) 
"A experiência fulcral que me levou a essa escolha foi um problema médico pessoal... eu apresentava problemas no joelho... Eu sempre tratei com médicos que não sabiam a causa desses problemas e realizavam tratamento paliativo... Cansado desses médicos, eu encontrei um médico que cuidou de mim de uma forma diferente. Ele me escutava, ouvia com cuidado o meu relato dos sintomas e, por fim, conseguiu me diagnosticar. ... levo comigo o exemplo de um grande profissional que fez crescer em mim uma grande admiração por essa profissão.” (Aluno, 25 anos)

“Com uma gestação difícil e alguns problemas médicos posteriores, meus primeiros anos de vida sempre foram cercados de profissionais da saúde que sempre me fizeram sentir seguro e querido..." (Aluno, 21 anos)

"O fascínio pelos meus médicos em consultas, tratamentos e cirurgias foi fundamental para despertar o interesse pela medicina. $\mathrm{O}$ cuidado e o sentimento de confiança eram mútuos e demonstravam a beleza da profissão. Justamente o fato de ter sido um paciente com cuidadores competentes abriu uma porta pra essa escolha." (Aluno, 17 anos)

\section{Adoecimento de parentes}

“... experiências que eu tive com familiares doentes (câncer) também despertaram minha vontade de participar do meio científico na pesquisa por mais conhecimento que possibilite ampliar as possibilidades de tratamento e prevenção de doenças de diversos tipos." (Aluna, 19 anos)

“... o tratamento dado ao meu avô, diagnosticado com câncer de próstata, me fez perceber a importância de um bom tratamento, tanto físico quanto psicológico, para o paciente e seus familiares, o que me fez ter certeza da profissão que desejo seguir." (Aluna, 18 anos)

"Naquele caso, eu era seu acompanhante e num momento de extrema necessidade vi o profissional médico atuando de forma além da prática técnica, no sentido de amparar o paciente numa situação emergencial. ... Decidi pela carreira médica a fim de conseguir fornecer àquele que necessita de cuidados uma atenção que vai além da técnica, abarcando aspectos mais humanísticos como o descompasso psicológico numa situação tão delicada." (Aluno, 20 anos)

"Essa escolha foi baseada em um episódio que ocorreu comigo quando tinha cerca de 10 anos. Estavam apenas eu e meu pai em casa... Estávamos assistindo televisão quando ele sofreu uma crise convulsiva. Eu nunca tinha ouvido falar daquilo. A sensação de impotência e medo diante de tal situação me fizeram tomar a decisão de ser médico. Não queria mais sentir aquilo, não saber o que fazer diante de uma emergência médica." (Aluno, 21 anos)

“... meu avô paterno sofreu um acidente de carro e entrou em coma. A partir de então, comecei a frequentar diariamente um hospital de minha cidade em que o meu avô estava na UTI. Assim, pude observar, por alto, o trabalho do médico, o qual me chamou bastante atenção pela capacidade de conforto e esperança que ele proporcionava para as pessoas." (Aluno, 19 anos) 
"Esse desejo [de ajudar as pessoas] surgiu a partir do momento em que meu pai foi diagnosticado com um problema neurológico grave, este sem cura, apenas tratamento de controle." (Aluno, 22 anos)

\section{Influência dos pais}

"Como meu pai é médico, cresci em contato com a profissão. Assim, desde pequena eu visitava o hospital e entrava em contato com diversos paciente, o que possibilitou que eu visse o papel desempenhado pelo médico e a diferença que ele faz na vida dos outros." (Aluna, 18 anos)

"Acredito na influência familiar para a escolha da profissão. Não houve pressão dos pais, ao contrário, a paixão demonstrada por eles me estimulou a escolhê-la." (Aluna, 18 anos)

"O fato de ambos meus pais serem médicos me influenciou muito. Mas não porque me pressionaram e sim porque as experiências vividas por eles com coisas intrigantes e as inúmeras cartas de agradecimento provindas dos pacientes me mostraram a beleza da profissão, ajudando sempre o outro, mesmo que com palavras ao invés de medicamentos." (Aluno, 18 anos)

"Eu acredito que o principal motivo que me levou a escolher a profissão médica foi a vivência com minha mãe e o constante contato com seu trabalho: a enfermagem. Desde pequeno percebi a potencialidade do cuidado e da empatia pelas pessoas como motores do bem-estar. Assim, ao observar os pacientes das Unidades Básicas de Saúde (UBS) deixando as salas com sorrisos no rosto ou mesmo com um pouco mais de tranquilidade, senti que deveria fazer parte disso." (Aluno, 19 anos)

"Meu pai (meu veterano, inclusive) soube me demonstrar desde pequeno a importância da profissão médica e de como superar os percalços da vida. Órfão de pai aos 13 anos, ingressou na FMUSP e foi meu exemplo de um bom médico e meu incentivador." (Aluno, 21 anos)

\section{Desejo de infância}

"Desde pequena, sempre gostei de cuidar dos outros, principalmente quando doentes, levando comida, água, chá, etc...." (Aluna, 18 anos)

"A medicina é um sonho antigo que surgiu na infância a partir da vontade de cuidar dos outros. Quando criança, sempre gostei de ajudar as pessoas e cuidar do meu irmão mais novo." (Aluna, 20 anos)

"Escolhi a profissão médica ainda muito pequena, por volta dos 7 anos de idade. Parte dessa escolha veio da fascinação infantil com o trabalho médico e parte pela vontade de ajudar o próximo." (Aluna, 18 anos)

"Desde pequena nutri o desejo de cuidar da saúde e do bem-estar das pessoas, possibilitando uma qualidade de vida, no mínimo, razoável." (Aluna, 20 anos) 


\section{A intenção de reproduzir modelos}

“... houve uma grande influência do meu pediatra - médico extremamente atencioso e humano. Eu sonhava em cuidar das pessoas como ele cuidava de mim." (Aluna, 20 anos)

“... optar por essa carreira seria essencial em minha vida. ... porque eu sinto uma gratidão enorme por todos os profissionais que trataram minha mãe da melhor forma possível e quero poder fazer o mesmo por outras pessoas." (Aluna, 20 anos)

“... conheci uma médica incrível, suas consultas faziam as crianças rirem, as conversas eram inesquecíveis (para os pacientes e para os alunos que ouviam), todos saiam sorrindo do consultório, o cuidado e carinho, tanto com as crianças e suas famílias como com os alunos que acompanhavam, me marcaram. Achei uma experiência incrível, que gostaria de repetir, propiciar o mesmo sentimento de conforto, de confiança que ela conseguiu, para pacientes que $m$ dia serão os meus.” (Aluna, 19 anos)

"Na minha família, possuo diversas mulheres inspiradoras que serviram de modelo e exemplo durante a minha formação. Entre elas, destaco minha madrinha, médica obstetra e ginecologista." (Aluna, 18 anos)

"A decisão de me tornar médico é, em grande parte, uma tentativa de proporcionar o cuidado que tiveram comigo quando necessitei a outras pessoas." (Aluno, 21 anos)

"Um outro fator que me fez sentir que realmente aquilo que eu queria fazer era medicina, foi o contato com um grande médico e além disso uma excelente pessoa, um exemplo de entrega ao cuidado com o próximo. Esse médico dedica a maior parte de sua semana para o cuidado com pessoas carentes... Esse médico atende tais pacientes em seu consultório particular, totalmente sem custos... Sempre com muita atenção, carinho e humanização. ... Isso me fez escolher a medicina, para um dia poder agir dessa maneira e ser um meio de melhorar a vida de alguém." (Aluno, 18 anos)

\section{Ações sociais e trabalhos voluntários realizados}

"Com aproximadamente 14 anos comecei a frequentar atividades voluntárias que me colocaram em contato com outras realidades - realidades distantes da minha, e isso foi um motivador para que eu escolhesse a medicina, pois eu entendi que através dessa profissão eu teria a oportunidade de transformar a vida e a realidade de outras pessoas." (Aluna, 20 anos)

“... o trabalho inspirador realizado por organizações como a Bandeira Científica, a Cruz Vermelha e o Médico sem Fronteiras me inspiraram e renovam minhas motivações para me formar como profissional médica." (Aluna, 20 anos) 
"No $2^{\circ}$ ano do colegial, fiz um trabalho voluntário no Instituto da Criança do HC e gostei muito de ter o contato com os pacientes e com o ambiente hospitalar. Depois de conversar com alguns médicos e engenheiros, decidi que na medicina teria a oportunidade de me realizar tanto na parte acadêmica, quando como ser humano." (Aluna, 18 anos)

"Com esse interesse [pelo corpo humano], passei a buscar projetos que me colocassem perto da atuação de profissionais de saúde, para entender sua realidade. Fui para um Quilombo 'atender' pacientes, onde conheci uma médica incrível... Achei uma experiência incrível, que gostaria de repetir, propiciar o mesmo sentimento de conforto, de confiança que ela [a médica] conseguiu, para pacientes que um dia serão meus." (Aluna, 19 anos)

"Com uns 10 anos, minha mãe me levou para projetos sociais da igreja, um dos projetos era a visita e ajuda ao "lar dos idosos" na cidade de Paulínia. Com isso, diante do contato com as pessoas nos projetos sociais, decidi que queria exercer uma profissão voltada para o cuidado das pessoas." (Aluna, 20 anos)

"Além disso [interesse pelo conhecimento científico], a experiência do Projeto 'Pão e beleza', um projeto realizado na minha cidade que oferece alimentação, banho, corte de cabelo e tratamento contra a dependência química a moradores de rua foi fundamental para despertar o desejo por cuidar dos que sofrem." (Aluno, 20 anos)

"Em 2011, um dos trabalhos escolares pedidos pelas professoras foi uma ação voluntária com uma instituição de auxílio a crianças carentes e em vulnerabilidade social... tive a chance de ouvir muitas dessas crianças e suas histórias. Elas contavam sobre parentes ou conhecidos importantes em suas vidas que estavam internados em hospitais públicos e sobre a dificuldade em seus tratamentos e atendimentos médicos. ... pude perceber o quanto a saúde é determinante para o bem-estar das pessoas (às vezes mais do que condições materiais), o que me levou a optar por uma área ligada ao cuidado em saúde.” (Aluno, 19 anos)

“... realizei um trabalho como bolsista no CAISM (Centro de Atenção Integral à Saúde da Mulher) entrevistando centenas de pacientes acerca dos serviços oferecidos pelo hospital. Essa experiência me fez refletir sobre as minhas escolhas profissionais, culminando na escolha pela profissão médica." (Aluno, 22 anos)

\section{Interesse pelo ser humano integral}

(fisiológico \& psicológico)

\section{Unir saber científico ao cuidado}

"Interesse pela área biológica / da saúde / gosto pelo cuidado e pesquisa / Amor por pessoas, laboratórios e hospitais." (Aluna, 18 anos) 
"Eu sempre soube que queria trabalhar ajudando pessoas de uma maneira em que houvesse contato direto com elas. Medicina surgiu como opção quando percebi que gostava muito de estudar e das áreas biológicas, e porque sentia que precisava cumprir um papel social." (Aluna, 18 anos)

“... participei de um projeto social que me fez confiar mais na minha habilidade de lidar com pessoas de forma humana. ... sempre gostei muito de estudar e do conhecimento científico, o que me fez escolher a profissão médica, que reúne o saber e o cuidado." (Aluna, 21 anos)

"... unindo meu desejo de contribuição para a sociedade, minha curiosidade de lidar com pessoas e meu fascínio pela vida, eu decidi pela profissão médica.” (Aluna, 18 anos)

"Hoje, penso em fazer medicina porque amo a área de humanas e também me relacionar com pessoas, mas também tenho muito interesse por pesquisas na área científica (gosto muito de química e de biologia).” (Aluna, 18 anos)

"Escolhi a carreira médica principalmente pela admiração e curiosidade em relação ao ser humano, o funcionamento do corpo e os fatores envolvidos neste funcionamento, não apenas físicos, mas também psicológicos e sociais. ... escolhi a medicina por esta aliar o conhecimento científico ao cuidado com seres humanos possibilitando a satisfação de meus interesses no âmbito acadêmico e social." (Aluna, 20 anos)

“... em todas as carreiras e cursos que eu poderia pensar em fazer há como ajudar o próximo, cada um a sua maneira. Porém, foi na Medicina que eu vi esse valor como cerne, que permeia todas as ações dos médicos. Isso, aliado ao meu interesse por Biologia e ciências no geral, me motivou a escolher a profissão médica." (Aluna, 19 anos)

"Observando o tratamento impessoal que muitos médicos dão ao paciente e a falta de um cuidado integral do ser humano, optei por me tornar médica para, além de cuidar da parte física do paciente, dar suporte psicológico e ajudá-lo a assumir uma postura de esperança." (Aluna, 19 anos)

“Com o tempo, fui desenvolvendo certo pensamento crítico em relação ao que é ser médico, às complicações da carreira, os estigmas, os problemas relacionados ao atendimento, ao acesso à saúde. A partir de então, a medicina se tornou mais do que entender o funcionamento do corpo humano, mas a possibilidade de proporcionar algum conforto para outra pessoa, ajudá-la de alguma forma.” (Aluna, 19 anos)

"Com a busca por uma nova carreira, passei a ver a profissão médica pelo lado "mais humano', pelo seu significado na vida das pessoas e na sociedade. Aliando a técnica e a significação, a escolha da medicina se tornou a melhor opção, a opção natural para mim." (Aluna, 30 anos)

"O que me levou a escolher a profissão médica foi o interesse de estudar o corpo humano em um primeiro momento. Porém, depois comecei a me interessar mais ainda em atender as pessoas e realizar algo que considero de muita importância na sociedade." (Aluno, 21 anos) 
“... eu sinto vontade de ajudar pessoas que passam por dificuldades / que sofrem e, portanto, a profissão médica me permite, tanto conhecer o corpo humano, como também utilizar esse conhecimento para aliviar, confortar e curar pessoas de suas dores, dificuldades e problemas." (Aluno, 20 anos)

“... a profissão médica alia tanto meu gosto pela ciência, quanto o meu desejo por cuidar dos que sofrem." (Aluno, 20 anos)

"Além da questão do cuidado com o próximo, a temática envolvida na medicina me atrai muito, a aproximação de matérias como química e física, aplicadas ao corpo humano e a promoção da saúde me desperta grande interesse." (Aluno, 20 anos)

“...sempre tive interesse em qualquer uma das 3 áreas do conhecimento acadêmico (bio, humanas e exatas). ... Encontrei na medicina uma forma de conciliar todos os 3 tipos de conhecimento, desde analisando a subjetividade do paciente e a estrutura social na qual se encontra até estudando os potenciais elétricos na fisiologia de um neurônio." (Aluno, 21 anos)

\section{Transdisciplinaridade}

"Eu sempre me interessei por todas as disciplinas escolares e por diversos tipos de atividades frequentemente incompatíveis umas com as outras. Assim, o principal motivo pelo qual escolhi a profissão médica foi porque vi na medicina uma maior interdisciplinaridade do que em outras carreiras." (Aluno, 19 anos)

"Medicina foi minha escolha porque é uma área do conhecimento humano na qual é possível encontrar vertentes de diversas outras áreas, como as ciências humanas e expressões artísticas. Nesse contexto, uma vez que sempre me atraí por matérias muito distintas entre si - como história, química, artes, filosofia e física -, eu escolhi medicina porque espero ser passível de uma grande comunhão e fusão do conhecimento humano." (Aluno, 17 anos)

\section{Ajudar pessoas}

"Eu sempre soube que queria trabalhar ajudando pessoas de uma maneira em que houvesse contato direto com elas." (Aluna, 18 anos)

"Parte dessa escolha [pela profissão médica] veio da fascinação infantil com o trabalho médico e parte pela vontade de ajudar o próximo.” (Aluna, 18 anos)

"Para mim, o ato de ajudar o outro, se doar pelo outro, é o que atribui algum significado à vida." (Aluna, 19 anos)

“... decidi ser, um dia, médica, porque gosto de lidar com o ser humano, procurar entende-lo e ajudá-lo." (Aluna, 18 anos) 
"O motivo principal da minha escolha pela carreira médica foi por vontade de ajudar o outro, principalmente as populações mais carentes..." (Aluna, 19 anos)

"Eu percebi a diferença que um médico pode fazer na vida das pessoas e o fato de poder ajudar alguém diretamente e aliviar um pouco o sofrimento sempre me fascinou." (Aluna, 18 anos)

"Eu sempre desejo ajudar quando elas necessitam, principalmente quando sua saúde e sua vida estão em risco." (Aluna, 21 anos)

"A vontade de ajudar pessoas, melhorar seu sofrimento." (Aluno, 20 anos)

"A necessidade e a vontade de atenuar os sofrimentos alheios me conduziram à medicina." (Aluno, 19 anos)

"...eu sinto vontade de ajudar pessoas que passam por dificuldades/que sofrem..." (Aluno, 20 anos)

"O desejo de ajudar me guiou em direção à escolha da carreira médica..." (Aluno, 20 anos)

"Penso que o gosto, de certa forma precoce, pelo assunto [Medicina] foi apenas uma confirmação do que eu desde pequeno quis ser: alguém que ajuda o outro. Vejo-me como uma pessoa disposta a ajudar e cuidar; sinto-me bem em relacionar e criar afeto com outros..." (Aluno, 20 anos)

"O que me levou a escolher a profissão médica, além de me identificar com a área de atuação foi, sobretudo, o desejo de poder ajudar outras pessoas.” (Aluno, 22 anos)

\section{Melhorar a vida das pessoas}

"Escolhi essa profissão para melhorar a qualidade de vida das pessoas, gerando bemestar social." (Aluna, 18 anos)

"A possibilidade de poder contribuir para melhorar a qualidade de vida dos meus próximos ultrapassa meros gostos por equações químicas ou sistemas biológicos. Precisava continuar nesse caminho: precisava me tornar médico.” (Aluno, 19 anos)

"A necessidade de servir outras pessoas de forma a fazer grande diferença em suas vidas tanto de forma física quanto psíquica foi o meu motivo de escolha desta profissão." (Aluno, 19 anos)

"Isso me fez escolher a medicina, para um dia poder agir dessa maneira e ser um meio de melhorar a vida de alguém." (Aluno, 18 anos) 


\section{Aspecto sociopolítico da Medicina}

\section{Transformação social}

“... eu entendi que através dessa profissão eu teria a oportunidade de transformar a vida e a realidade de outras pessoas." (Aluna, 20 anos)

"A medicina foi a [profissão] que mais me atraiu. Não só pelo belo trabalho que um médico faz, mas também pela ótima sensação de que eu poderia contribuir para melhorar o Brasil. ... com a medicina, eu senti que conseguiria exercer a profissão sem duvidar do potencial da prática médica em melhorar a sociedade." (Aluna, 19 anos)

"A escolha da profissão médica se deve ao meu interesse em ajudar o próximo e contribuir para certa mudança social. Na medicina posso encontrar não só aspectos biológicos como também aspectos mentais e sociais, e esses dois últimos foram importantes na minha decisão. Durante meu ensino médio, tive contato com discussões reflexivas e questionadoras, o que me levou a buscar essa essência na profissão médica." (Aluno, 18 anos)

"A realidade da saúde pública mostrada na mídia, com pacientes alojados em corredores e médicos sem interesse algum no auxílio aos doentes sempre me deixou indignado e isso fez com que eu escolhesse a medicina para tentar, ao mínimo, ser um exemplo de médico que se preocupa com as pessoas e, se possível, para tentar modificar alguns desses cenários.” (Aluno, 17 anos)

"Acho que a medicina permite que eu me torne um agente de transformação social, papel que eu gostaria de desempenhar (acho que eu devo desempenhar, na verdade)." (Aluno, 21 anos)

\section{Papel social do médico}

"Acredito que deva ser extremamente gratificante poder ajudar as pessoas dessa forma e assumir as responsabilidades sociais de um médico." (Aluna, 22 anos)

"O interesse pelo conteúdo [biológicas] somou-se à possibilidade de cumprir um papel social que a profissão fornece e cuidar da saúde, direito fundamental a todos da população." (Aluna, 19 anos)

"A experiência [de acompanhar o cotidiano de um médico] consolidou a decisão em cursar medicina para desenvolver o melhor de mim como cidadão e profissional visando contribuir socialmente." (Aluno, 20 anos) 
Contribuir para a melhora do sistema de saúde brasileiro

"Já presenciei e ouvi relatos de influências negativas [do profissional da saúde], o que me incentivou a tentar fazer a diferença, principalmente no sistema público, pois a ideia de que os serviços são ruins neste já está disseminada." (Aluna, 22 anos)

“... ao me deparar com as precárias condições de saúde do nosso país, me senti motivada a tentar mudar essa realidade e prover um atendimento digno às pessoas." (Aluna, 20 anos)

"As idas a hospitais públicos como paciente me proporcionaram experiências positivas e negativas a respeito do SUS que me incentivaram a participar como profissional buscando a melhora do sistema para que os ideais que originaram o projeto sejam colocados em prática." (Aluna, 22 anos)

"...sentia que eu poderia contribuir com a saúde no Brasil com a minha sensibilidade." (Aluna, 20 anos)

"Depois que decidi que prestaria medicina, passei a notar em como está a situação do sistema de saúde brasileiro, o que me motivou ainda mais. Por vir de uma cidade com menos de 30 mil habitantes e ainda na área rural [Mirandópolis-SP], minha indignação só cresceu." (Aluna, 19 anos)

\section{Aspecto econômico da Medicina}

Oportunidades amplas no mercado de trabalho

“... levei em conta o grande espaço no mercado de trabalho." (Aluna, 20 anos)

“... fui pesquisando cada vez mais sobre as áreas de atuação médica e a amplitude dessa profissão.” (Aluno, 19 anos)

\section{Estabilidade Financeira}

“... levei em conta a estabilidade da profissão.” (Aluna, 19 anos)

"Essa opção pela medicina foi distante de busca por qualquer prestígio social, mas contou a possibilidade de estabilidade financeira." (Aluno, 19 anos)

“... a estabilidade financeira que essa profissão pode me proporcionar condiz com meus objetivos de vida, que incluem financiamento de projetos artísticos voltados para a reabilitação de pacientes..." (Aluna, 17 anos) 


\title{
Ascensão social
}

"Tal escolha se deveu em muito à lembrança de uma infância conturbada por problemas econômicos." (F20)

"Em grande medida a faculdade de medicina é uma escolha baseada em minhas origens sociais e histórico de vida. ... cursar uma universidade pública de qualidade também é um importante vetor de transformação não só pessoal e financeira mas também no próprio contexto de desigualdade social do país. ... O orgulho de ser filho de nordestino com um imigrante japonês com poucas perspectivas, sendo o primeiro a se graduar reflete em toda a sociedade." (M30)

\begin{abstract}
ANEXO C
Conjunto completo de discursos referentes à Pergunta 2 - Humanizar é ... Complete com suas palavras.
\end{abstract}

\section{Compreensão Humana}

\section{Contexto social}

“... ver além da dimensão técnica, observando que por trás de uma doença ou diagnóstico existe também um ser humano, imerso em suas questões étnicas, socioeconômicas e culturais." (Aluna, 18 anos)

“... tratar o outro como ser humano, considerando seus aspectos físicos, mentais e sociais." (Aluna, 18 anos)

“... analisar também o seu lado psicológico, sua história de vida e sua condição social, coisas que muitas vezes são muito relevantes no tratamento e no cuidado do paciente." (Aluna, 18 anos)

"Humanizar é tornar o tratamento com as pessoas mais sensível, levando a atenção para o âmbito psicológico e social do paciente, ou seja, ao seu estilo de vida, seus sentimentos, sua história, pelo que ele passa até chegar ao posto de saúde." (Aluna, 17 anos)

“... promover o cuidado ao paciente levando em conta o aspecto social, psicológico e físico deste.” (Aluna, 22 anos)

“... tratar e cuidar de alguém entrando em contato com sua realidade, entendendo que o sofrimento e o desconforto são causados por inúmeras variáveis, sejam elas físicas, psicológicas ou sociais." (Aluna, 20 anos) 
"Ao tratar todos os aspectos de um paciente, sendo estes o físico, o psicológico, o social, etc., há humanização do tratamento...” (Aluna, 18 anos)

"Humanizar é ajudar o próximo de maneira física, psicológica e social, dando-lhe o apoio, afeto e carinho necessário que possibilita a passagem mais branda deste por um problema pessoal." (Aluna, 22 anos)

"É considerar sua origem social, cultural, entender como ele compreende o mundo, suas limitações e seus sentimentos em geral." (Aluna, 19 anos)

“... cuidar do 'paciente' como um todo (abrangendo as esferas sociais, psicológicas, culturais etc.)..." (Aluna, 18 anos)

"Na área médica a humanização é poder tratar do paciente não apenas no seu aspecto físico, buscando como único objetivo encontrar um diagnóstico correto, mas sim tratar do paciente humano que veio em busca de cuidado e que possui além do aspecto físico um aspecto social e psicológico." (Aluna, 19 anos)

“... tornar o atendimento médico mais completo, fazendo com que ele englobe não apenas os aspectos físicos do paciente, como também os aspectos mentais, emocionais e sociais." (Aluna, 17 anos)

"Tratar da saúde física e mental do paciente, considerando sua condição social e fazendo isso com comunicação efetiva." (Aluna, 23 anos)

"Humanizar é ... incluir no cuidado com o paciente a noção de que ele é um sujeito que merece atenção. Essa atenção, porém, não deve ser apenas nos aspectos físicos... Ela deve focar no estado psicológico do paciente e no contexto social a que ele pertence." (Aluna, 19 anos)

“... fazer com que o tratamento da saúde não fique restrito à preocupação com a doença física, mas abranja também o aspecto psicológico e social do paciente." (Aluna, 19 anos)

"Reconhecer o outro como humano, um ser com história, carga emocional e contexto social. Mais do que apenas reconhecer, é lidar com o fato de que todas essas implicações interferem na saúde e na qualidade de vida da outra pessoa. É saber, de maneira prática e concreta, como lidar com essa pessoa de forma a não negligenciar todo o seu entorno." (Aluna, 18 anos)

“... tratar o paciente com o devido respeito, compreendendo todo o contexto envolvido, que ultrapassa simplesmente tratar o paciente." (Aluno, 18 anos)

"Humanizar é ouvir o paciente em esferas que excedem o âmbito médico, como a esfera pessoal, cultural e psicológica. Os sintomas de um paciente podem surgir, ou serem potencializados por fatores não fisiológicos. A humanização, portanto, permite um diagnóstico e um tratamento amplo, completo e total.” (Aluna, 25 anos)

"Humanizar é tornar o atendimento médico mais acolhedor, levando em consideração os aspectos sociais, mentais e físicos dos pacientes." (Aluna, 19 anos) 
"... exercer alteridade e, na medida do possível, compreender a situação do outro, como as dificuldades que ele enfrenta." (Aluno, 18 anos)

"Tratar com respeito e acolhimento, atendo-se às necessidades 'físicas, psicológicas e sociais' de qualquer um que demande cuidado e atenção.” (Aluno, 19 anos)

"Humanizar é, mais do que curar, amenizar o desconforto, aliviar dores, sejam elas físicas, psíquicas ou sociais." (Aluno, 17 anos)

"Cuidar do corpo, do psicológico e se preocupar com os fatores sociais do paciente." (Aluno, 19 anos)

"Reconhecer no paciente suas necessidades e angústias para além da área clínica, envolvendo aspectos sociais, pessoais, políticos e culturais; buscando atentar para todos esses fatores no desempenho da profissão médica." (Aluno, 22 anos)

"Humanizar é entender o objeto de estudo como um ser biopsicossocial." (Aluno, 19 anos)

“... humanizar é entender um paciente como um sujeito dotado de subjetividade e imerso em um contexto sócio-histórico e, não, um objeto com uma disfunção." (Aluno, 19 anos)

"Humanizar é ver o outro como seu semelhante e respeitar as diferenças, aceitar a pluralidade de cada indivíduo e entender que todo ser humano é complexo e possui suas próprias ideias e cultura." (Aluno, 26 anos)

“... enxergar o paciente como ser humano, dotado de aspectos não só físicos/patológicos, mas também sociais e psicológicos, e oferecer amparo e cuidado nesses aspectos da melhor forma possível..." (Aluno, 20 anos)

"Analisar e lidar com o ser humano de uma forma holística, levando-se, assim, em consideração aspectos emocionais, culturais, metafísicos e outros intrínsecos a um indivíduo no processo de atendimento médico.” (Aluno, 17 anos)

“... tratar dos pacientes levando em conta não apenas sua enfermidade física, mas também seu estado psicológico e social." (Aluno, 18 anos)

"Humanizar é prover um tratamento que englobe todos os aspectos do ser humano, valorizando os âmbitos psicológico, físico e social do paciente.” (Aluno, 20 anos)

"Humanizar é consolidar em toda a esfera médica que o tratamento e o cuidado com o paciente devem englobar aspectos físicos, mentais, sociais e emotivos, a fim de que o paciente receba a devida atenção e dedicação (tanto profissional quando interpessoal) que o tratado merece." (Aluno, 19 anos)

"Tratar o próximo não somente como paciente, mas como uma pessoa, que tem sentimentos e experiências que fazem dela única. Além disso, essa pessoa está envolvida na sociedade, e todas as disparidades inerentes dessa devem ser levadas em conta na composição da relação entre médico e paciente." (Aluno, 20 anos) 
"... tratar o paciente como um humano, considerando suas características éticas, sociais, culturais, econômicas e sentimentais." (Aluno, 19 anos)

\section{Contexto emocional}

"Humanizar é olhar o outro sabendo que é um ser que sofre, que ama, que odeia e que precisa de ajuda..." (Aluna, 20 anos)

"Humanizar é enxergar o paciente como um ser humano, com sentimentos, experiências, família." (Aluna, 19 anos)

"Humanizar é ir contra ao processo de reificação da sociedade, em que o homem passa a ser visto como 'coisa'. Processo resultante de uma sociedade cada vez mais competitiva e de laços afetivos frágeis. A humanização, portanto, é um resgate da visão do próximo como um ser humano que possui angústias, medos e principalmente necessidade de afeto." (Aluna, 19 anos)

“... tornar as relações interpessoais mais afetivas...” (Aluna, 25 anos)

"Humanizar é reconhecer o paciente como uma pessoa com sentimentos, dores, histórias, angústias, medos..." (Aluna, 18 anos)

"Humanizar é deixar a relação médico-paciente mais afetuosa." (Aluno, 21 anos)

“... tratar não só do paciente, mas também dos indivíduos ao redor como humanos, respeitando seus direitos e, principalmente, entendendo seu lado emocional e seus sentimentos." (Aluno, 17 anos)

"Reconhecer no paciente suas necessidades e angústias para além da área clínica..." (Aluno, 22 anos)

"Humanizar é captar tudo aquilo que não está explícito, é perceber as dores e angústias mais escondidas e ter a capacidade de lidar com elas." (Aluno, 21 anos)

"Humanizar é valorizar, cultivar e incentivar a manifestação desses sentimentos tipicamente humanos, tais como a empatia, o amor ao outro e, sobretudo, o sentimento de pertencimento a um todo chamado humanidade que precisa constantemente do altruísmo para existir e evoluir." (Aluno, 18 anos)

“... enxergar nas pessoas seres humanos, ou seja, seres com sentimentos, emoções, tristezas, alegrias." (Aluno, 18 anos)

"Tratar as pessoas como seres humanos, dotados de sentimentos, vontades, angústias, emoções e não como um objeto a ser analisado, estudado." (Aluno, 22 anos)

"Tratar o próximo com respeito, atenção e dedicação, considerando-o como um ser humano que possui suas necessidades e problemas, que podem ser sanados ou aliviados, e não o considerando como um simples objeto de estudo sem levar em conta seus 
sentimentos, sensações, medos, angústias e tudo o mais que faz parte do ser humano." (Aluno, 26 anos)

\section{História pessoal}

"É compreender que o outro com que se está lidando tem uma história, e respeitar essa história." (Aluna, 20 anos)

"É propor um tratamento menos tecnicista na medida em que se procura conhecer a história do paciente, atende-lo olhando em seus olhos." (Aluna, 20 anos)

"É levar em consideração que essa pessoa possui toda uma história de vida, relações sociais e dificuldades que nem sempre são expostas." (Aluna, 18 anos)

"É enxergá-la [a pessoa] empaticamente e tratá-la como seu igual, respeitando suas dúvidas e anseios e buscando compreender sua história - ainda que esta não seja compatível com a nossa ou mesmo que traga valores distintos àqueles que acreditamos." (Aluna, 20 anos)

"Englobar no paciente não somente seu corpo físico, mas a história de vida que carrega e compreender, dessa forma, por trás daquele prontuário, sua humanidade." (Aluna, 19 anos)

"Um atendimento humanizado compreende carinho e dar importância à história do paciente..." (Aluna, 18 anos)

"Tratar a pessoa, no caso da medicina o paciente, não como um corpo ou objeto de estudo, mas como um ser possuidor de uma história." (Aluna, 20 anos)

“... ter respeito. Respeito com a história do outro e o que ele tem passado." (Aluno, 18 anos)

"Diferentemente de outras profissões em que o objeto de estudo é inanimado, na medicina lida-se com pessoas, que possuem, não apenas uma doença, mas também uma história de vida, sentimentos." (Aluno, 18 anos)

"Não só uma melhora no atendimento ao paciente, como também adotar um olhar diferente daquele meramente técnico, enxergando na pessoa a ser atendida um ser humano com uma história de vida, alegrias, tristezas e problemas que vão além de uma simples doença." (Aluno, 20 anos)

"Humanizar é enxergar o outro. É saber, ou querer saber, do outro - sua história, seus desejos, sonhos, medos, angústias. ... É tratar, como pessoa, o outro, considerando suas 'bagagens' histórica, cultural, social.” (Aluno, 20 anos) 


\section{Atitudes Humanas}

\section{Acolher}

"Humanizar é cuidar dos cidadãos de forma que esses indivíduos sejam acolhidos." (Aluna, 20 anos)

"Humanizar é acolher e ajudar as pessoas..." (Aluna, 20 anos)

“... dentro do âmbito da saúde, desenvolver empatia pelo paciente para que desta forma o acolhimento e o tratamento deste seja feito de uma maneira mais 'aconchegante'." (Aluno, 38 anos)

“... humanizar é tornar o atendimento médico mais acolhedor..." (Aluno, 19 anos)

"Humanizar é dar um bom atendimento, acolher o paciente..." (Aluno, 18 anos)

"Humanizar é transformar o ambiente do consultório ou do hospital em um lugar acolhedor e feliz." (Aluno, 19 anos)

\section{Confortar}

"Confortar ... oferecendo outra esfera de cuidado no tratamento que além de buscar curar ... também busca promover o bem-estar do paciente...” (Aluno, 17 anos)

"Prestar um atendimento que ... consiga atingir o paciente de forma a confortá-lo..." (Aluno, 20 anos)

"É tornar o ambiente da consulta mais confortante de modo a tranquilizar o paciente..." (Aluno, 21 anos)

"É mostrar que o paciente não apenas está sendo tratado, mas também cuidado e confortado." (Aluno, 19 anos)

\section{Promover bem-estar}

“... promover, além da saúde objetiva, a saúde subjetiva do paciente, garantindo sua integridade biológica e psicológica de forma a lhe trazer conforto e bem-estar. (Aluna, 18 anos)

"Humanizar é cuidar da pessoa e de suas carências para receber sua confiança e proporcionar o bem-estar que ela busca." (Aluna, 22 anos)

"É tratar o paciente como pessoa, a qual precisa do bem-estar para viver plenamente, e não apenas sobreviver." (Aluna, 18 anos) 
"Fornecer ao paciente o amparo necessário à situação física, psicológica, além da adequação social à realidade dele a fim de atender o objetivo de tentar promover o bemestar a ele." (Aluno, 20 anos)

“... [oferecer] uma outra esfera de cuidado no tratamento que além de buscar curar (pondo fim ao mal estar) também busca promover o bem estar do paciente, que não é definido apenas pela ausência de doenças." (Aluno, 17 anos)

“... deve-se entender os valores e crenças do outro e buscar ao máximo o bem-estar físico e psicológico...” (Aluno, 19 anos)

"Humanizar é, em um contexto de saúde e atendimento médico, agir de modo humano para com o paciente... a fim de garantir-lhe bem estar..." (Aluno, 17 anos)

"[É usar] o toque, a compreensão, o ouvir, o contato visual, entre outras medidas que mostrem a preocupação do médico quanto ao bem estar físico, psicológico e social do paciente." (Aluno, 18 anos)

“... humanizar é interessar-se com sinceridade pelo bem estar dos pacientes..." (Aluno, 18 anos)

"Humanizar é dar atenção e cuidado, visando proporcionar bem-estar." (Aluno, 20 anos)

“... humanizar é buscar não somente a cura de uma doença, mas a melhora do bem-estar do indivíduo como um todo.” (Aluno, 20 anos)

"Humanizar é promover um atendimento médico de qualidade que vise ao tratamento físico, mental e social do paciente, promovendo seu bem-estar nessas três áreas..." (Aluno, 19 anos)

“... garantir o bem estar pessoal do paciente, tanto fisicamente e psicologicamente, quanto socialmente." (Aluno, 19 anos)

\section{Respeitar}

"Humanizar é respeitar o paciente qualquer que seja sua formação; social, profissional e moral; e tentar ao máximo deixar claro que ambos (médico e paciente) são humanos e que ambos são falhos e que não é porque um passou anos se qualificando para tratar outros que ele é melhor, e que muito menos possui o direito de legitimação para subjugar ou desrespeitar o outro.” (Aluna, 19 anos)

"O ato de humanizar pode ser entendido como o ato de cuidar da vida e pode ser traduzido por imagens de respeito com o outro tanto no sofrimento como na alegria..." (Aluna, 21 anos)

“É tratar do paciente com igualdade e respeito." (Aluno, 21 anos)

"Humanizar é deixar a relação médico-paciente mais afetuosa e de respeito mútuo..." (Aluno, 21 anos) 
"... tratar o paciente com o devido respeito, compreendendo todo o contexto envolvido..." (Aluno, 18 anos)

“... ter respeito. Respeito com a história do outro...” (Aluno, 19 anos)

"Tratar com respeito... a humanização deve contar com uma relação amigável entre paciente e profissional. $\mathrm{O}$ cuidado com ambas as partes conduzirá a relação/consulta a um estágio de respeito, atenção e carinho." (Aluno, 19 anos)

"Respeitar e reconhecer a pessoa com quem você está tendo contato..." (Aluno, 21 anos)

\section{Tratar com empatia}

"Deve-se entender que além da relação médico-paciente, encontra-se pessoas cuidando de pessoas, ou seja, somos humanos, devemos manter nosso lado humano e empático vivo dentro de nós, mostrando a importância que cada um tem e a atenção de que cada um é merecedor." (Aluna, 22 anos)

“... se relacionar com as pessoas, empaticamente e levando em conta suas individualidades." (Aluna, 21 anos)

“... dentro do âmbito da saúde, desenvolver empatia pelo paciente...” (Aluno, 38 anos)

"Humanizar é ter empatia. Compadecer com as dores dos outros; regozijar-se com a alegria também." (Aluno, 19 anos)

“... é enxergar o processo de cura dos pacientes sob os olhos da empatia, e não sob os olhos da produção industrial.” (Aluno, 19 anos)

“É a empatia, a capacidade de compreender a dor do outro." (Aluno, 19 anos)

\section{Labirinto Humano}

\section{Singularidade}

"Humanizar é conjugar empatia à técnica de forma a considerar... os aspectos humanos, individuais e únicos do sujeito com o qual se está interagindo. Humanizar, dessa forma, é potencializar o auxílio.” (Aluna, 19 anos)

"É exercer a medicina como um ato de amor ao próximo, procurando ajudar, ouvir e cuidar de cada pessoa como sendo única." (Aluna, 19 anos)

"Atentar à condição ímpar do outro, tratá-lo como um indivíduo com angústias e sonhos válidos e cuidá-lo de forma dedicada, virtuosa e tolerante." (Aluna, 18 anos) 
"Entender que cada paciente que entra no hospital ou no consultório é uma pessoa diferente, com uma história, com medos, com vontades e, portanto, cada consulta é distinta. Humanizar é compreender que o paciente está confiando seu corpo ao profissional da saúde, o bem mais importante que ele tem, e é preciso dar valor a isso. Humanizar é tratar com a mesma significância que o paciente o breve momento do atendimento." (Aluno, 19 anos)

“É adaptar a postura médica diariamente, moldando as indicações de tratamento conforme o panorama pessoal de cada indivíduo atendido." (Aluno, 19 anos)

"Tratar o próximo não somente como paciente, mas como uma pessoa, que tem sentimentos e experiências que fazem dela única." (Aluno, 20 anos)

"Humanizar é realizar toda e qualquer atividade voltada para seres humanos com a plena consciência de suas particularidades, subjetividades, buscando a compreensão do próximo..." (Aluno, 21 anos)

“... tratar as pessoas como pessoas. Cada um tem seus anseios, preocupações, medos e realidades. É difícil enxergar o mundo de outra perspectiva que não a de nossos olhos, mas é uma experiência fascinante. Quando no metrô ou na calçada, enxergar que cada uma daquelas pessoas vivem experiências, amou, foi amado, brigou, chorou e tem uma história completamente única. ... Humanizar é entender que todos merecem a atenção e os cuidados melhores, visto que são plenos em sua singularidade." (Aluno, 19 anos)

\section{Complexidade}

"O médico deve estar comprometido em sair do automático e observar o paciente como um ser humano, com necessidades e complexidades que vão além da moléstia." (Aluna, 22 anos)

"É ver o paciente como um ser humano complexo, com desejos, sentimentos e necessidades." (Aluna, 18 anos)

"Humanizar é compreender que o outro é um ser humano tão complexo quanto si mesmo com sua história, angústias, seus desejos, seus valores e tratá-lo como tal." (Aluna, 18 anos)

“... embasar as relações médico-paciente com a complexidade da vivência humana." (Aluna, 19 anos)

“... olhar para o outro. Ver nele uma essência, uma história, emoções e sentimentos. Humanizar é lidar com o próximo considerando integralmente sua pessoa, que é complexa, múltipla.” (Aluna, 20 anos)

"Agir numa relação médico-paciente como numa relação interpessoal complexa, lidando com as interações e demandas bilaterais: expectativas, necessidades, sentimentos, sem hierarquia ou condescendência." (Aluna, 30 anos) 
"... lembrar que se trata de seres humanos, que são muito complexos e únicos." (Aluno, 21 anos)

"O ato de um sujeito, ao analisar outro sujeito humano, entender muito mais do que as superficialidades associadas ao contexto em que se encontrou, como, por exemplo, uma doença no caso de um ambiente clínico; mas toda a complexidade da humanidade inerente a este, englobando as esferas física, mental e social: o estado atual e a história de vida." (Aluno, 19 anos)

"Humanizar é lembrar que apenas o conhecimento técnico não abarca a complexidade humana. ... Humanizar é prezar pela vida valorizando o indivíduo e suas complexidades, estabelecendo relações interpessoais efetivas e não superficiais." (Aluno, 17 anos)

"Tratar um ser tão complexo quanto o humano como números e resultados diagnósticos é subestimar a vida." (Aluno, 19 anos)

\section{O doente / a doença}

"Humanizar é cuidar do paciente no âmbito biopsicossocial, dentro do nosso alcance, e não simplesmente cuidar de doenças ou buscar a cura." (Aluna, 21 anos)

"Humanizar é reconhecer que não há apenas doentes em uma unidade de saúde, há pessoas, tais quais os profissionais, que buscam o saber tecnocientífico aliado a um atendimento humano." (Aluna, 22 anos)

"Humanizar é tratar o paciente como um ser humano, e não como a doença que ele apresenta." (Aluna, 18 anos)

“... cuidar dos pacientes entendendo claramente que antes de serem portadores de uma doença, eles são pessoas e merecem respeito, atenção e o comprometimento do profissional da saúde em dar o melhor de si." (Aluna, 19 anos)

"Saber que a doença não define a pessoa, a qual tem uma identidade maior própria." (Aluna, 19 anos)

"Humanizar é ter consciência de que o paciente não é um objeto de estudo e a ser curado, mas sim uma outra pessoa, com uma história de vida, emoções, pensamentos e ideias, e que portanto merece ser tratada como tal." (Aluna, 18 anos)

“... um médico não enxerga o paciente como um mero portador de uma patologia a ser estudada, mas como um ser humano próximo e que precisa de todos os tipos de amparo, e não apenas uma prescrição médica e um atestado." (Aluna, 18 anos)

"Humanizar é tratar o paciente menos como caso clínico e mais como pessoa, levando em consideração suas experiências de vida, crenças e medos...” (Aluna, 22 anos)

“É cuidar do paciente como uma pessoa e não como um objeto.” (Aluno, 21 anos) 
"Atender o próximo não somente de maneira técnica, mas atenciosa, que confere conforto em um momento difícil." (Aluno, 23 anos)

"Diferentemente de outras profissões em que o objeto de estudo é inanimado, na medicina lida-se com pessoas, que possuem, não apenas uma doença, mas também uma história de vida, sentimentos." (Aluno, 18 anos)

"Promover um tratamento da forma mais humana, ou seja, não reduzir seu paciente a uma mera patologia, deve-se entender os valores e crenças do outro..." (Aluno, 19 anos)

“... tratar o doente, não a doença.” (Aluno, 19 anos)

“... cuidar do outro como um ser complexo e não somente uma doença." (Aluno, 19 anos)

“... enxergar o paciente como ser humano, dotado de aspectos não só físicos/patológicos, mas também sociais e psicológicos...” (Aluno, 20 anos)

"Tratar o paciente não como um número, um conjunto de informações ou sintomas, mas como um indivíduo, uma pessoa." (Aluno, 19 anos)

“É perceber que o paciente tem nome, e não apenas uma infecção.” (Aluno, 19 anos)

"Na área médica, humanizar seria começar a estudar o paciente como um todo, e não apenas a doença." (Aluno, 21 anos)

"Humanizar é colocar o ser humano à frente da doença, é pensar naquela pessoa como um todo (visão holística)..." (Aluno, 18 anos)

"Humanizar é tratar o paciente e não a doença. É dar atenção aos detalhes da vida do paciente..." (Aluno, 23 anos)

"Enxergar o paciente não como uma doença, mas como um ser humano dotado de particularidades psicológicas e sociais que influem em uma percepção geral a respeito de sua própria saúde e de seu bem-estar." (Aluno, 19 anos)

\section{Horizontalidade}

"Humanizar é respeitar o paciente qualquer que seja sua formação; social, profissional e moral; e tentar ao máximo deixar claro que ambos (médico e paciente) são humanos e que ambos são falhos e que não é porque um passou anos se qualificando para tratar outros que ele é melhor, e que muito menos possui o direito de legitimação para subjugar ou desrespeitar o outro." (Aluna, 19 anos)

"Reconhecer que toda forma de contato humano caracteriza uma relação horizontal de ensino e aprendizagem, agindo-se de acordo." (Aluna, 26 anos)

"Humanizar é ter em mente que somos todos merecedores dos mesmos direitos humanos e agir de acordo com esse pensamento." (Aluna, 19 anos) 
"É enxergá-la [a pessoa] empaticamente e tratá-la como seu igual, respeitando suas dúvidas e anseios e buscando compreender sua história..." (Aluna, 20 anos)

“O contato humano-humano (não médico-paciente), horizontal, é muito rico. É por meio dele que se pode conhecer e reconhecer as semelhanças entre nós, a essência que nos torna vivos." (Aluna, 18 anos)

"É tornar o ambiente de consulta mais confortante de modo a tranquilizar o paciente e tratar dele com igualdade e respeito." (Aluno, 21 anos)

“... dar ao seu objeto de estudo, um ser humano, o seu devido valor. Não obstante, relacionar-se de maneira horizontal com ele. Isto é, deixar evidente que não há quaisquer traços de hierarquia ou constrangimento na relação.” (Aluno, 20 anos)

"Humanizar é deixar de ver o paciente como uma lista de sintomas para vê-lo como um igual." (Aluno, 20 anos)

"Humanizar é ter a humildade de ver as pessoas em seu valor em si: SERES HUMANOS. ... É lembrar-se sempre de que a relação médico-paciente é SEMPRE humano-humano, e NUNCA humano-objeto." (Aluno, 19 anos)

\section{Si mesmo e o outro}

"É ter alteridade, colocar-se no lugar do outro e reconhecer nele semelhanças e diferenças, para assim poder agir da melhor maneira possível..." (Aluna, 18 anos)

"Não temer o olhar alheio, é se enxergar, tal qual reflexão, no seu semelhante. É se arriscar além da bolha impenetrável na qual nos aprisionamos, é negar o egocentrismo, é entender o outro como uma extensão do próprio ser. É desconstruir as fortalezas que construímos em torno de nós mesmos; é permitir ao outro um mecanismo de entrada." (Aluna, 18 anos)

"Cuidar dos outros da forma como gostaríamos de ser cuidados ou da forma que gostaríamos que aqueles de quem gostamos fossem cuidados.” (Aluna, 22 anos)

"Além de compreender as dificuldades e barreiras de si mesmo e do outro para saber o limite e a necessidade de cada um." (Aluna, 22 anos)

"É se colocar no lugar dele e entender seus medos e dúvidas acerca do tratamento..." (Aluna, 19 anos)

"Lembrar que o paciente é humano, assim como o profissional de saúde." (Aluna, 19 anos)

"Humanizar, para mim, seria a forma de tratar o outro do jeito que você gostaria de ser tratado." (Aluna, 18 anos) 
"Humanizar é esquecer-se por um momento de seus próprios problemas para pensar no outro, no que ele está sentindo, em seus anseios e suas frustrações. Humanizar é nunca se esquecer de tratar o outro como você gostaria de ser tratado." (Aluna, 19 anos)

"À medida que nos reconhecemos no outro, o cuidado torna-se mais efetivo, a preocupação torna-se real.” (Aluna, 18 anos)

“O paciente deve ser visto como tão humano quanto você." (Aluno, 19 anos)

"Humanizar é, acima de tudo, compreender o outro e percebê-lo como pessoa... Além disso, humanizar é enxergar o outro em si mesmo, sendo, portanto, capaz de tomar a dor alheia para si, de forma a melhor compreendê-la e ser capaz de buscar amenizá-la com mais afinco." (Aluno, 19 anos)

"Tornar um tratamento humanizado é exercer a função de médico com seu coração, buscando o bem do paciente como se buscaria o próprio bem." (Aluno, 17 anos)

"Humanizar é reconhecer-se como um ser humano atendendo outro ser humano em uma relação bilateral de aprimoramento mútuo e sem discriminação." (Aluno, 19 anos)

“... compreender a existência de vida no paciente e no médico.” (Aluno, 19 anos)

"Humanizar é tratar o paciente com uma proximidade saudável, tanto para o enfermo quanto para o médico. É se por na situação daquele que pede ajuda a você, com isso tornando possível entrar em contato com ele de forma a ultrapassar a simples análise do 'caso'." (Aluno, 18 anos)

"É o ato de cuidar de si e do outro, encarando-o como um ser pensante digno dos mesmos direitos. ... É trabalhar pelo gosto de cuidar, e não apenas pelo salário de cada mês." (Aluno, 19 anos)

"Humanizar é entender que a relação médico-paciente é uma via de mão dupla. É entender que tanto o médico quanto o paciente aprendem em uma consulta. Humanizar é captar tudo aquilo que não está explícito, é perceber as dores e angústias mais escondidas e ter a capacidade de lidar com elas." (Aluno, 21 anos)

"Humanizar é trazer à tona o melhor que existe em você e nas pessoas... é ouvir e não deixar de falar aquilo que pode ser essencial para outra pessoa." (Aluno, 19 anos)

"Penso 'humanizar' então como sinônimo de 'ter empatia', pois se colocar no lugar do outro é um jeito interessante de desconstruir o modelo biomédico vigente por tantos anos." (Aluno, 18 anos)

“... tratar o paciente como se ele fosse a nossa mãe.” (Aluno, 19 anos)

"É difícil enxergar o mundo de outra perspectiva que não a de nossos olhos, mas é uma experiência fascinante.” (Aluno, 19 anos)

“... ver o outro como se fosse um irmão, mãe, pai, avô, avó, enfim, como alguém por quem você tem carinho especial.” (Aluno, 18 anos) 


\section{Tratamento Humano}

\section{Ir além}

"Prestar um atendimento que ultrapasse a barreira do conhecimento técnico e consiga atingir o paciente de forma a confortá-lo..." (Aluno, 20 anos)

"Aproximar médico e paciente, diminuir o abismo criado pelo ensino puramente técnico." (Aluno, 18 anos)

"No caso da prática médica, humanizar é tornar a relação médico-paciente mais humana, no sentido de torná-la mais sensível e combater ao máximo a transformação dessa relação em um procedimento meramente técnico." (Aluno, 18 anos)

"Atender o próximo não somente de maneira técnica, mas atenciosa..." (Aluno, 23 anos)

"Humanizar é, na medicina, proporcionar um cuidado integral, isto é, que leva em conta não apenas o lado tecnicocientífico, mas também a humanidade e a subjetividade do paciente..." (Aluno, 17 anos)

"Humanizar é não somente se ater à tecnicidade da profissão, mas também trazer ao ambiente profissional práticas éticas, morais e sociais ao se relacionar com o público, desconstruindo-o como um mero objeto, passando a tratá-lo como um ser humano." (Aluno, 23 anos)

“... humanizar é interessar-se com sinceridade pelo bem estar dos pacientes, conjugando conhecimentos / habilidades técnicas e habilidades relacionais em prol do tratamento do enfermo." (Aluno, 18 anos)

"Compreender que o momento de fragilidade do paciente não deve ser resolvido de maneira puramente técnica e científica, mas de maneira que faça com que o doente se sinta acolhido e amparado, se sinta um ser humano, e não um mero objeto de estudo do médico." (Aluno, 20 anos)

"Humanizar é conciliar a tecnologia com o respeito à vida." (Aluno, 23 anos)

"Humanizar requer a mobilização de conhecimentos técnicos avançados mas não se resume a isso; envolve usar terapêutica clínica com uma parte do tratamento oferecido ao paciente, procurando constantemente entender outros fatores não necessariamente de natureza biomédica mas que desempenham um determinado papel em sua saúde." (Aluno, 19 anos)

“... ver além da dimensão técnica, observando que por trás de uma doença ou diagnóstico existe também um ser humano, imerso em suas questões étnicas, socioeconômicas e culturais." (Aluna, 18 anos)

"A humanização é simples e não exige o último avanço tecnológico para se efetivar, basta o desejo de olhar o outro e olhar pelo outro." (Aluna, 21 anos) 
"Compreender que, além do conhecimento técnico-científico aprendido com estudos, livros e aulas, existe um ser humano por trás do diagnóstico." (Aluna, 18 anos)

"Humanizar é o ato de conciliar o saber técnico à proximidade com o paciente. Os avanços tecnológicos permitem melhores oportunidades de diagnóstico, tratamento e prevenção de doenças. Contudo, é necessário que se leve em consideração o fato de que o paciente é um ser humano com dúvidas, sentimentos, problemas, angústias. Nesse sentido, é papel do médico proporcionar, da melhor forma possível, um bom atendimento, seja no sentido técnico, seja no entendimento dos anseios mentais e sociais do ser humano que pede ajuda." (Aluna, 19 anos)

\section{Descoisifcar / Desmaquinizar / Desautomatizar}

"Estar presente, em um estado de 'mindfulness', ao falar com o paciente, realmente ouvindo o que ele tem a dizer ao invés de descartar informações e atender de forma automática." (Aluna, 22 anos)

"Humanizar é ir contra o processo de reificação da sociedade, em que o homem passa a ser visto como 'coisa'. Processo resultante de uma sociedade cada vez mais competitiva e de laços afetivos frágeis." (Aluna, 19 anos)

"Humanizar é, principalmente, deixar de fazer com que o paciente seja uma coisa, ou seja, somente um objeto de estudo e tratamento. Humanizar é fazer com que o paciente sinta-se como pessoa, tratado com respeito e possuindo direito por boas condições em seu atendimento." (Aluna, 18 anos)

"Humanizar é não-mecanizar as relações interpessoais..." (Aluna, 18 anos)

"Confortar, impedindo a maquinização da profissão médica, oferecendo outra esfera de cuidado no tratamento...” (Aluno, 17 anos)

“... buscar um contato mais próximo com [o paciente], de modo a suprir suas necessidades ... com empatia e boa vontade - e não meramente de modo "mecanizado" / tecnificado -, a fim de garantir-lhe bem-estar e, quando necessário, tratamento clínico." (Aluno, 17 anos)

"Humanizar é um modo de encarar situações e pessoas, os 'descoisificando'." (Aluno, 26 anos) 


\begin{abstract}
ANEXO D
Conjunto completo de discursos referentes à Pergunta 3 - Narre uma experiência de humanização ou desumanização vivida por você, utilizando quantas linhas forem necessárias.
\end{abstract}

\title{
Desumanização
}

\section{No olhar}

"Na consulta, a médica não levantou os olhos do computador quando entrei, mal me olhou ao me examinar e apenas disse que não era nada, sem nenhuma explicação." (Aluna, 18 anos)

“... Contudo, dos mais de seis médicos pelos quais passei nos últimos anos, no máximo dois olharam nos meus olhos e me trataram como uma pessoa que também tem seus medos e inseguranças.” (Aluna, 18 anos)

"Ouvi várias queixas da minha avó sobre a insatisfação com alguns médicos. Ela disse que um deles sequer olhou para ela e ficou só olhando a tela do computador. Percebi claramente a desumanização nesse processo, que a fez se sentir menosprezada em um momento que o que ela mais precisava era de atenção..." (Aluna, 18 anos)

"Uma experiência de desumanização que vivi foi quando fui ao médico, clínico geral, devido a problemas de gastrite. No atendimento o médico nem olhou para mim e se manteve olhando apenas para o computador." (Aluna, 18 anos)

"Já vivenciei uma experiência de desumanização com um atendimento em um hospital de rede particular. Consultei-me no pronto atendimento e quando entrei na sala do médico, não houve nenhum contato ou olhar. $\mathrm{O}$ médico permaneceu olhando para a tela do computador e digitando o que eu relatava. Quando parei de contar o que tinha e comecei a tirar dúvidas sobre o que estava se passando, o médico olhava para a tela do seu celular e começou a checar suas redes sociais, nem respondia as dúvidas." (Aluna, 19 anos)

“... um médico que não olhava na cara, não conversava...” (Aluno, 25 anos)

“... eu fui a uma dermatologista em Florianópolis, e ela sequer olhava para mim enquanto falava. Simplesmente perguntava e preenchia o prontuário.” (Aluno, 23 anos)

"A última experiência desse tipo [desumanização] foi no mês de janeiro quando fui a um dermatologista que mais se preocupava em anotar meus sintomas em seu novo programa de computador do que escutar e examinar o que eu tinha a dizer." (Aluno, 20 anos)

“... Não era nada sério, no entanto, quando fui a uma consulta médica, o médico de plantão não me examinou, nem olhou sequer nos meus olhos durante a consulta." (Aluno, 23 anos) 
"... A médica que me atendeu não me recebeu bem, não perguntou meu nome nem nada; simplesmente (sem nem olhar pra mim) perguntou 'E aí? O que tá acontecendo?"' (Aluno, 20 anos)

“... já fui a vários médicos que não olhavam para mim e ficavam só digitando no computador." (Aluno, 18 anos)

"Há dois anos fui atendido por um médico em um hospital particular que realizou uma consulta por somente 10 minutos e a maior parte do tempo ficou digitando no computador e mal olhou em meus olhos." (Aluno, 19 anos)

"Sofri uma experiência de desumanização na qual, ao ser atendido por um clínico, este constantemente digitou no seu computador, nem sequer perguntando meu nome na entrada no consultório. Não houve contato visual e a desatenção do médico era tamanha que tive que repetir sintomas." (Aluno, 19 anos)

\section{No descaso}

“... Não houve questionamentos a respeito do motivo do [meu] estresse, não houve conselhos, não houve qualquer tipo de interação que ultrapassasse as 'cordialidades' superficiais que se resumiram a um 'boa tarde' e aperto de mãos. O médico se ateve somente aos resultados dos exames e a perguntas a respeito do coração, ignorando completamente meu quadro de saúde como um todo." (Aluna, 18 anos)

“... No dia marcado para a [minha] cesárea, apesar do meu direito de ter acompanhante o tempo todo, fiquei afastada da minha família em todo o pré-operatório. E assim que eu filho foi retirado da minha barriga, meus acompanhantes foram mandados embora e fiquei completamente sozinha, sem meu filho e nem acompanhantes, por horas [...]. Eu estava sem qualquer meio de comunicação com minha família e sem notícias do meu filho. Para mim, isso foi uma completa desumanização no tratamento a mim e à relação entre eu e meu filho." (Aluna, 21 anos)

“... Em uma situação de crise de pânico tal familiar sempre acredita que está tendo um infarto, e geralmente ignoram essas queixas e só repassam a receita de remédios, o que parece não mais fazer sentido para mim, pois anos de crise de depressão não são resultado de uma descompensação bioquímica apenas, há todo um contexto que desencadeia esses problemas que me parece ser ignorado por aqueles médicos que rotineiramente o atendem em consultas." (Aluna, 18 anos)

"Tenho uma tia distante médica, que sempre se refere a seus pacientes como simples doenças, constantemente fala que prefere trabalhar na UTI pois há menos conversa com pacientes, não se relaciona com eles, e ainda conta, em tom de deboche, queixas que ouve daqueles que atende. Desde cedo a relação dela com seus pacientes me trazia aflição. Como alguém que cuida de doentes em situações tão graves pode ter aversão à relação com eles?" (Aluna, 19 anos)

“... Eu estava com medo. Chegando no hospital, o médico me atendeu de maneira ríspida e ficou menosprezando e ironizando meu medo..." (Aluna, 19 anos) 
“... acompanhando um paciente em estado de surto devido a um transtorno bipolar, vi o médico psiquiatra endurecer o tom com esse paciente, o qual não estava tomando os remédios adequadamente e apresentava uma postura agressiva. $\mathrm{O}$ paciente, perdendo a paciência com o médico, começou a gritar. O médico, em vez de tentar controlar a situação ou resolver o problema do surto, mandou o paciente sair do consultório. $\mathrm{O}$ paciente continuou por meses nesse surto, sem apoio médico." (Aluna, 19 anos)

"Durante a consulta, o médico não me perguntou meu nome, não se interessou sobre a minha história, simplesmente restringiu-se à dor que eu sentia." (Aluno, 18 anos)

"Inúmeras foram as situações de desumanização quando eu estava doente e o médico menosprezava o caso. Por exemplo, o uso da frase: 'Isso é apenas uma dor de cabeça'." (Aluno, 18 anos)

"Em março de 2014 minha mãe foi atropelada... quando ocorreu a internação ela sentia dores na perna e no ombro, o interno que atendeu falou que não era nada, só hematomas. Descobrimos que a perna estava quebrada e o ligamento acromioclavicular rompido, além de duas costelas quebradas. É uma tortura quando o paciente está sofrendo de dor e o médico diminui uma sensação do outro." (Aluno, 16 anos)

"Em um hospital privado, havia um familiar meu que estava passando por diversos exames para a realização de cirurgia. $\mathrm{O}$ episódio de desumanização deu-se quando o médico responsável pelo aval a ser dado ao meu familiar sequer se deu ao trabalho de explicar ao paciente ou à família os resultados dos exames e seus significados, em um comportamento de completo descaso com a situação emocional das pessoas envolvidas." (Aluno, 17 anos)

\section{No diagnóstico}

“... um médico que não olhava na cara, não conversava, recomendou-me uma cirurgia que hoje sei que era desnecessária e não resolvia meu problema." (Aluno, 25 anos)

"O médico presente fazia atividades secundárias durante a consulta e ainda fez um diagnóstico errado de glaucoma, descoberto por um médico do HC." (Aluno, 19 anos)

"Quando criança, ao passar numa consulta com uma cardiologista num posto de saúde a fim de ser examinado e diagnosticado que estava bem para praticar esportes [...], a profissional não me examinou e só escreveu sem nem me tocar. Ela poderia, talvez, diagnosticar meu sopro, o que só vim descobrir a existência anos depois." (Aluno, 19 anos)

"Pronto socorro público da cidade de Taubaté, São Paulo, uma menina de 7 anos esperava na sala lotada com dores pulsantes da região abdominal. Os funcionários estavam desumanizados devido à intensa pressão do ambiente, ao sucateamento do serviço e às baixas condições de trabalho. Tal ausência do humanizar era cíclica, foi do sistema para o pronto socorro; do pronto socorro para os funcionários; dos funcionários para os pacientes; dos pacientes para o sistema em críticas, descrédito e ofensas. A 
menina esperava angustiada, havia passado já por aquele lugar nos dois dias anteriores, fora diagnosticada como intoxicação alimentar nas duas primeiras, mas a dor não passou. Suas primeiras consultas haviam sido rápidas, mal se expressando dentro da sala devido à dor e ao medo daquele lugar em que todos pareciam endurecidos. Finalmente, na consulta daquele dia o outro médico foi mais compreensivo, tocou-a, escutou atentamente o caso exposto pelos familiares. Ela foi encaminhada com urgência para a cirurgia. Era apendicite." (Aluno, 19 anos)

"Durante o ano de 2014, mais especificamente entre os meses de maio e junho, minha família levou minha vó ao hospital, pois essa estava emagrecendo muito e mal conseguia se alimentar. Durante o atendimento o médico nem mesmo tocou na minha vó, apenas disse que era uma dor de estômago comum e passou uma receita. Próximo do mês de dezembro, minha vó muito magra e debilitada ainda estava extremamente relutante em voltar ao hospital, pois confiava na opinião do primeiro médico. Depois de muitos pedidos, ela resolveu voltar ao hospital, mas buscamos outro médico para ter uma segunda análise. Nessa ela foi constatada com câncer no pâncreas já em estado terminal, vindo a falecer no mês de dezembro de 2014. A pior experiência da minha vida foi ver a minha vó definhando e não poder fazer nada, confiando em um médico que nem exames minimamente profundos pediu. (Aluno, 20 anos)

"A partir de setembro de 2014, minha mãe notou a presença de um inchaço em seu pescoço. Ao procurar um 'médico', ele disse se tratar de uma simples íngua, causada por uma gripe que ela havia contraído no mês anterior. Tal diagnóstico foi feito sem contato e bem rapidamente. Aquele inchaço só fazia crescer, e, após duas idas ao mesmo hospital, o diagnóstico se mantinha. Em abril de 2015 eu precisei passar em uma consulta de acompanhamento no A.C. Camargo [...]. O médico com quem faço tal acompanhamento se prontificou a avaliar a queixa da minha mãe, que estava lá comigo. Ele a tocou, pediu que ela colocasse a língua para fora e outras medidas que o primeiro 'profissional' não havia feito. O último médico, então, pediu a ela alguns exames e disse que, assim que os resultados saíssem, ela poderia trazê-los mesmo sem hora marcada. [...] Esses exames mostraram que a tal íngua, dita inofensiva, era na verdade um reflexo de um tumor maligno que minha mãe tinha na base da língua. A falta de humanização do primeiro 'médico' o fez ignorar sinais clínicos que atrasaram em seis meses o tratamento de minha mãe." (Aluno, 19 anos)

\section{Nas relações humanas contemporâneas}

"Diariamente utilizo o metrô como meio de transporte e é neste local que vejo quase sempre exemplos de desumanização. No dia 22 de fevereiro, por exemplo, por volta das 18 horas, estava voltando para casa com o metrô lotado, uma moça que estava sentada em um dos acentos notou que uma senhora, que estava passando por um tratamento de um câncer, entrou no trem; nesse momento a moça cedeu-lhe seu lugar, mas antes mesmo da senhora conseguir sentar outra pessoa pegou o lugar liberado pela moça e a senhora ficou de pé o restante do percurso.” (Aluna, 22 anos)

"Em um domingo estava indo a uma festa com minha família quando vi uma menina pedindo esmola na rua. Enquanto eu estava arrumada, ia me divertir e comer na festa, essa menina, que deveria ter a minha idade, estava na rua, com roupas velhas, sem 
dinheiro, sem comida, exposta ao crime e à violência, sem moradia e sem ter oportunidade de ir à escola. Ela não parecia um ser humano, mas somente algo no meio da rua. Para mim essa foi uma experiência de desumanização, pois a menina não tinha os direitos e condições básicas de qualquer ser humano." (Aluna, 18 anos)

“... uma experiência de desumanização está associada a um tratamento reificado que experimentei no exterior. Na tentativa de tirar dúvidas em um aeroporto, o atendente não buscou saná-las e as respondeu de qualquer maneira." (Aluno, 19 anos)

"No metrô de manhã, com o acontecimento de problemas técnicos, os trens estavam circulando em menos velocidade, e portanto, atrasados. Com isso, houve superlotação dos mesmos. Eu estava na estação esperando o metrô, que chegou lotado, mas mesmo assim havia indivíduos empurrando mulheres contra o trem lotado para não esperar o próximo trem, o que gerou discussões entre os passageiros.” (Aluno, 17 anos)

"Uma experiência de desumanização se deu no metrô de São Paulo, em uma manhã típica de caminho para a escola. Estava esperando o trem, e quando ele chegou, na porta do lado da minha saiu uma senhora passando muito mal e se deitou na plataforma de modo a obstruir a passagem. Após isso, as pessoas dessa porta se desviavam para entrar no trem sem dar atenção à senhora, e logo um funcionário foi 'ajudá-la'. Claramente tal ajuda não visava cuidar desta senhora, mas sim desobstruir a passagem." (Aluno, 18 anos)

"A experiência que eu vivi ano passado, durante o curso pré-vestibular, foi uma experiência de desumanização. $\mathrm{O}$ fato de eu ter tido que estudar 10 horas / dia fez com que minhas relações sociais com a família e amigos se enfraquecessem e com que eu desenvolvesse crises de ansiedade." (Aluno, 19 anos)

“... a desumanização acontece quando há falta de respeito; quando se é ignorado, no sentido de marginalizado, excluído, segregado. Estar numa roda de amigos e ser o único a não ser cumprimentado quando alguém se junta à roda - como se você não estivesse ali - é uma experiência de desumanização.” (Aluno, 20 anos)

\section{Humanização}

\section{Em ações sociais}

"Na escola onde estudei existia um projeto de educação (EJA), que ocorria à noite e consistia em aulas de diversas matérias para jovens e adultos sem uma educação formal completa. Junto com mais 2 colegas, deram-me a oportunidade de planejar o curso de inglês e dar as aulas. Essa experiência, acredito, foi cheia de 'humanização'. Conheci, ao longo do tempo, a história de todos os meus alunos, tive que entender a realidade social deles, muito distinta da minha, para assim entender suas demandas. A aula planejada tinha sempre de ser alterada para acompanhar o ritmo dos alunos, mantê-los entretidos à noite após um dia de trabalho e para conseguir de fato alcançá-los. Perceber as particularidades do grupo e de cada um, criar um vínculo, estabelecer uma relação de confiança e superar todas as dificuldades de ensinar uma língua nova, acredito, foi uma experiência de humanização." (Aluna, 18 anos) 
“... Passei os meses seguintes [ao fato de não passar no vestibular] trabalhando com refugiados sírios em centros de acolhimento em São Paulo. Meu papel era apenas ensinar um português básico para que eles pudessem iniciar seu processo de socialização na realidade brasileira. No entanto, ouvir aquelas primeiras palavras, um misto de português e árabe, de português e francês, fizeram-me entender que a comunicação, ao menos um pouco, permitida por mim, é o que os tornará um pouco mais brasileiros." (Aluna, 18 anos)

"No $2^{\circ}$ ano do colegial eu fui como ajudante com uma equipe de médicos e dentistas para o Quilombo de Ivaporunduva. O posto de saúde era uma casinha vazia e não havia como operar ou realizar procedimentos mais complexos no local. Uma mulher, paciente, entrou na sala com uma ferida de machado na perna. A impossibilidade de realizar procedimentos convencionais ou prescrever remédios (ela não iria conseguir comprá-los e não tínhamos levado) não impediu que o médico a tratasse, improvisando técnicas e se utilizando do material disponível." (Aluna, 19 anos)

"Trabalhei na ONG Vidas como voluntária. A ONG objetivava realizar atividades recreativas com crianças e adolescentes deficientes, além de promover assistência aos pais. Acho que nesse espaço vivenciei uma experiência de humanização ao conversar com pais que relatavam suas dificuldades como se precisassem desabafar. Achei chocante: nunca antes tinha ouvido sobre os desafios de ter um filho deficiente, incluindo as despesas mais elevadas aliadas à necessidade de atenção integral." (Aluna, 19 anos)

"Quando visitei Cananeia no Ensino Fundamental com o colégio, houve um projeto de distribuição de brinquedos para crianças carentes, tal ação ressaltou o caráter de cuidar das pessoas, intrínseco a qualquer ser humano devido ao sentido de realização e dever cumprido por mim e, provavelmente, por todos os outros estudantes." (Aluno, 18 anos)

"Uma experiência de humanização vivida por mim foi uma visita (com um grupo de alunos do colégio) para uma comunidade quilombola, com o objetivo de, com o auxílio de três médicos e alguns professores, ajudar a suprir as necessidades básicas de saúde da população bem como conhecer e estudar sua história. Essa visita proporcionou um contato íntimo entre os alunos e a população, de forma que cada um de nós pode compartilhar afetos com alguns dos habitantes da população.” (Aluno, 19 anos)

"Participei durante dois anos de uma instituição filantrópica chamada Interact Club, vinculada ao Rotary Club International. Nesse grupo, havia várias experiências de humanização, como uma visita à casa de idosos que fazíamos todos os meses. Nessas visitas, aprendíamos a respeitar as pessoas e, muito além disso, levávamos felicidade, carinho e atenção a pessoas que, muitas vezes, eram esquecidas por seus próprios familiares. Em troca, recebíamos a gratidão dessas pessoas que, com seus olhares e sorrisos, ensinavam-nos a sermos mais humanizados." (Aluno, 17 anos)

"No colégio em que estudei há uma parceria com uma ONG, a ONG Vidas. Essa organização atende crianças com deficiências físicas e motoras, e um certo dia, nós da equipe de basquete fomos convidados para participar das suas atividades. Essa ação foi muito enriquecedora pois pude perceber que a alegria está baseada em pequenas ações e receber um sorriso dessas crianças foi extremamente bonito e é algo que me lembro até 
hoje. Essa experiência certamente caminhará comigo em minha prática médica, e a busca por mais sorrisos como aquele será o meu maior objetivo." (Aluno, 21 anos)

"Em meio a tamanho individualismo e egocentrismo dos dias atuais, humanizar torna-se sinônimo de colocar-se na situação de um semelhante que necessita de algum tipo de auxílio. Nesse sentido vem uma cena em minha cabeça. Quando num dia de extremo frio eu estava andando pela rua e notei que um morador de rua passava muito frio; por instantes me vi num conflito interno no qual senti a necessidade de ceder minha própria blusa ao indivíduo, porém submetendo a mim mesmo a tamanho frio. Felizmente tomei a decisão correta e entreguei meu agasalho. Depois de feito, não houve seque um pingo de arrependimento comprovando que a gratificação em ajudar o próximo poderia ser um dos motores na carreira que escolhi." (Aluno, 20 anos)

"Certa vez, um conjunto de profissionais e estudantes da área da saúde foram até uma creche/asilo para crianças com deficiências físicas, sendo que eu também estava junto. Logo que adentramos o local as crianças ficaram excitadas, saltitantes e sorridentes, afinal, uma visita era algo incomum para elas. Dentro da creche, então, os profissionais e os estudantes na área da saúde vestiram-se de palhaços e divertiram os enfermos. Ao mesmo tempo em que havia risadas, porém, havia atenção médica, já que os profissionais de saúde atentavam para as condições das crianças. Ao fim da visita, tanto crianças enfermas quanto o grupo de profissionais e estudantes da área da saúde sentiam-se mais realizados e, com certeza, o sofrimento daquelas crianças fora amenizado." (Aluno, 18 anos)

"Certo dia, caminhava de volta para casa. Pela avenida onde passava, cruzei com um morador de rua, o qual pedia-me moedas pra almoçar no bom-prato. Ai invés de desconversar, pedi que me contasse sua história. Acabei conhecendo Wanderley, exdetento do Carandiru, escritor e poeta anônimo, que me encantou com sua história durante a tarde daquele dia. Filho de um professor, cursou Direito mas desistiu para viver a vida com plena liberdade. Narrou-me suas viagens de infância pelas terras áridas do Norte de Minas Gerais até a Zona Norte de São Paulo, onde ambos residimos. Wanderley fugia de uma cirurgia de remoção de prótese há quase 10 anos, tal qual foi implantada devido a um acidente (atropelado por uma moto). Tentei convencê-lo a operar, porém sua convicção e vontade de potência calavam-me. A história desse poeta tomou-me muitas noites de insônia e inspirou-me muito mais do que julgava saber. Sou eternamente grato a Wanderley, e sempre que posso forneço-lhe um caderno e canetas." (Aluno, 21 anos)

"Humanização é a possibilidade de um simples momento de atenção com o outro poder marcar as pessoas ou até transformar vidas." (Aluno, 20 anos)

"Meu avô foi a pessoa mais humana que já conheci. [...] Havia algo de especial nele. [...] Ele não via pessoas, ele via almas e as tratava todos igualmente. Uma de suas histórias foi que ele ajudou uma família muito pobre da cidade comprando um terreno e montando uma casinha para morarem. [...] A gratidão dessa família persistiu por todos esses 30 anos. [...] O fato é que a humanização se espalha quando seres humanos são tratados como seres humanos." (Aluno, 19 anos) 


\section{No atendimento em saúde}

"Antes de ingressar na faculdade de medicina, eu fazia faculdade de farmácia, e lá participei de um projeto social de realização de exames e orientação em saúde para as pessoas de uma cidade carente. Lá eu tive uma experiência em humanização ao lidar com crianças e idosos do projeto e perceber que eu aprendia tanto quanto ou mais do que eu ensinava as pessoas. Fui com a visão de que eu tinha mais conhecimento do que elas, mas voltei com a sabedoria de que o conhecimento não se resume à ciência, mas também diz respeito à experiência de vida, e isso aquelas pessoas tinham muito mais do que eu e puderam contribuir com a minha formação e desenvolvimento pessoal, muito mais do que eu imaginava." (Aluna, 21 anos)

"Uma experiência de humanização que eu tive no início desse ano ocorreu durante a visita monitorada que eu e minha turma realizamos ao Instituto da Criança. Ali, nós fomos orientados a ler histórias para as crianças internadas, uma experiência, em si, bastante emocionante. No entanto, o momento que eu considerei mais marcante foi durante a visita a um dos quartos onde a mãe de um garoto começou a conversar comigo e com um colega sobre sua história de vida. O fato de ela não nos conhecer, mas, mesmo assim, demonstrar tanta gratidão por estarmos ali me mostrou como atitudes simples como o ato de ler uma história, ao humanizar uma situação como aquela, também contribuem para melhorar o ambiente de tratamento, não só dos parentes, mas também de seus familiares, tão dependentes de atenção quanto seus entes queridos e internados." (Aluna, 19 anos)

"Certa madrugada, me machuquei e fui encaminhada, com muita dor, ao pronto socorro da ortopedia, onde, devido ao horário e o dia da semana, não havia muitas pessoas. Após ser atendida e medicada, fui levada a uma sala na qual se encontrava, sozinha, uma paciente idosa na maca. Embora estivesse recebendo medicação, era perceptível que ela sentia dor, porém não deixou de se preocupar comigo, perguntou o que havia acontecido e se eu estava bem. Ao longo da madrugada, nos preocupamos uma com a outra; ajudei-a a se cobrir quando estava com frio, chamei enfermeiros quando acabou sua medicação e permaneci ao seu lado segurando sua mão para que pudesse sentir carinho de alguém que se importava com seu bem estar. Logo, acredito que a humanização de ambas as partes foi de extrema importância para a superação do momento difícil pelo qual passamos." (Aluna, 20 anos)

"No início de minha carreira como farmacêutico, trabalhei como corresponsável de uma drogaria situada numa região pobre da grande São Paulo. Nesta época tive oportunidade de desenvolver, junto com a equipe que comigo trabalhava, diversas ações no sentido não apenas de dispensar medicamentos prescritos, mas principalmente de prestar a devida atenção farmacêutica por meio do diálogo antes da dispensação e acompanhamento do tratamento dos clientes (feito por contato telefônico). Como resultado, houve não apenas ganho material (as vendas da farmácia aumentaram) como a satisfação pessoa oriunda de elogios e agradecimentos feitos pelos clientes, que deixaram, inclusive, de comprar em farmácias que praticavam preços mais baixos, para comprar conosco, tamanha era a qualidade do atendimento praticado por nós." (Aluno, 38 anos)

"Minha melhor amiga Ti e eu participamos de um projeto na Santa Casa para entender o funcionamento de UBSs. Como éramos de grupos distintos, ela compartilhou sua 
experiência comigo. Junto com os agentes da UBS, ela visitou uma senhora obesa que morava um pouco afastado do metrô Tiradentes. Levou consigo os remédios para a senhora. Enquanto a Ti me relatava a experiência, percebi o que é humanização: ser recebido no lar de uma senhora sem familiares que, apesar de ter funções locomotoras comprometidas, fazia de tudo para deixar o ambiente agradável. É, também, projetar nessa senhora o carinho que sente pela sua vó e querer ajudá-la, por mais que seja apenas uma visita." (Aluno, 19 anos)

"Uma experiência interessantíssima foi contar histórias infantis a crianças hospitalizadas no Instituto da Criança (ICr), em que o aspecto de humanização presente em uma visita sem compromisso médico-paciente foi essencial a essas crianças." (Aluno, 19 anos)

"Quando no Ensino Médio fiz uma visita ao GRAAC. Lidar com esta situação é difícil, mas enfrentar o medo de ir lá e conversar com crianças com câncer foi muito gratificante. Há uma transparência na criança que é recoberta no adulto; é nítida a felicidade das crianças em encontrar alguém com quem possam brincar e conversar, sem ter que falar sempre sobre a doença ou seus prognósticos. Tratar o paciente como um ser humano, entender do que necessita e o que os alegra. Como visitante, é mais simples pois não cuidamos da doença; como médico, o desafio é muito maior, mas nunca deve-se perder de vista que a interação interpessoal é muito importante em qualquer tratamento, e na vida." (Aluno, 19 anos)

\section{No ambulatório social}

"Semana de Recepção dos Calouros da Faculdade de Medicina da USP. Todos estavam em êxtase para conhecer os arredores e a própria faculdade e para que esse mundo fosse desnudado uma das propostas foi o Ambulatório Social. Nós, alunos, fomos divididos em grupos e eu, particularmente, fui para o Instituto da Criança com o propósito de contar histórias. A expectativa pessoal era de encontrar crianças que interagissem comigo e com a história que fosse contar, mas quando cheguei no local fui designada a uma criança em estado pós cirúrgico e com aproximadamente 4 anos de idade. Ela não poderia responder a mim. Confesso que fiquei receosa. Decidi por iniciar a história, ainda que desconfortável e de forma inexperiente. Fui surpreendida. Ao longo da história aquela criança me olhava tão fixamente e nem reclamava em relação ao procedimento médico ao qual era submetida - atitude que costumava ter, segundo a enfermeira que a atendia. O olhar daquela criança foi tão forte que descobri que ela só precisava de alguém que lhe desse atenção, alguém que dispusesse a lhe fazer sorrir e com isso aliviar sua dor. Descobri que a humanização é menos conceito e mais prática. (Aluna, 21 anos)

"No momento, a experiência de humanização mais marcante foi a nossa visita ao ambulatório na semana de recepção. Nós deveríamos perguntar aos pacientes o que eles entendiam por ser um bom médico. Quase unanimemente os pacientes ressaltaram a importância de escutar, ouvir, olhar no olho, dar atenção. Não se queixaram da técnica, 
mas sim da prática, do contato humano. Esse é um episódio que vai permanecer na minha mente para sempre." (Aluna, 19 anos)

"O meu primeiro contato ostensivo com uma ação humanizada foi o Ambulatório Social realizado durante a semana de recepção da FMUSP, no qual fui enviado, junto de outros dois calouros e orientados por uma segundo anista, ao ICHC para conversarmos com os pacientes. No meu caso, conheci duas pacientes com infecção intestinal, e acho que tal experiência contribuiu enormemente para a minha formação na medida em que elas, na condição de pacientes, puderam me dizer o que esperavam de um bom médico (que as ouvissem mais), que era, de fato, algo que eu não imaginava ser crítico em um atendimento." (Aluno, 18 anos)

"uma experiência de humanização foi a visita realizada ao HC em fevereiro de 2016. Nela houve a possibilidade, apesar de ainda calouro e não exercer uma atuação médica, de conversar e ouvir os pacientes, entender seus problemas e assegurá-los que estão em boas mãos." (Aluno, 19 anos)

"Talvez a grande, e recente, experiência de humanização, que tive o privilégio de viver, tenha sido a atividade do 'Ambulatório Social', durante a semana de recepção, realizada no HC. A ocorrência do contato com a paciente, sem uma relação proeminentemente médica, permitiu um reconhecimento entre seres humanos e principalmente essa valorização da vida humana por ambas as partes. Tendo visitado uma paciente da obstetrícia, a experiência foi ainda mais impactante. Tratam-se, pois, de duas vidas humanas envolvidas e do respeito por ambas. Apesar de uma conversa de menos de uma hora, pude ver em seu semblante uma admiração pelo meu ingresso, a qual compartilhei, pela sua força. Foi uma vivência essencial, que ressaltou os princípios humanistas e de cuidado tão caros à prática médica. Espero, assim, que possam ser recorrentes ao longo do curso e da profissão." (Aluno, 19 anos)

"Eu participei do projeto 'ambulatório social': nele pude lidar com a paciente. Adalva, sem interagir, diretamente, com seu quadro clínico. Assim, pude trazer conforto à paciente mesmo sem analisá-la do ponto de vista patológico." (Aluno, 17 anos)

“A família de sua 'companheira de quarto' estava presente, rodeando o leito da mesma. Conversavam em voz alta e, apesar de possuir um membro internado, ainda conseguiam saborear algumas gargalhadas ao lembrar de histórias passadas. Mas ela não. Ela estava só e desamparada, mesmo no horário de visitas; olhava calmamente para sua bandeja enquanto comia. Entrei na sala e me apresentei. Ela se surpreendeu: apesar de já ter sido avisada sobre uma possível visita de primeiro anistas da FMUSP, de alguma forma a minha presença ao lado de seu leito no ICHC despertou nela um sorriso. Ele não durou muito, porém. A medida que conversávamos sobre o que era ser um bom médico, lágrimas escorreram de seus olhos ao mencionar experiências pessoais desagradáveis ocorridas naquela mesma manhã. Não sabia como reagir: a conversa havia parado. Minha 'paciente' estava aos prantos em minha frente, sem conseguir falar uma só palavra. Não: meu pensamento estava errado. Amassei e guardei o roteiro da visita: na minha frente chorava muito mais que um paciente, chorava um humano. Estratégia? Falar sobre o oposto. Ela havia mencionado que gostava de um Dr. Felipe. Lembrei-lhe dele. A conversa fluiu. Consegui me despedir deixando-a com um sorriso no rosto." (Aluno, 19 anos) 
"Realizei uma visita ao ICr (Instituto da Criança) durante a semana de recepção dos calouros e pude interagir com os pacientes, lendo histórias e executando algumas atividades de recreação." (Aluno, 22 anos)

\section{Na percepção/atenção/comunicação}

"Há alguns meses, enquanto ainda estava no cursinho, precisei ir ao pronto-socorro por conta de uma inflamação na garganta. Eu estava receosa de perder meu tempo em um hospital enquanto poderia estar em casa descansando; só fui porque minha mãe insistiu. Quando o médico me atendeu, mostrou-se interessado pela minha história, meus estudos e meu sonho de ser médica. Além da receita dos remédios, ele me deu atenção e uns bons conselhos." (Aluna, 22 anos)

"Certa vez necessitei fazer uma pequena operação, muito simples, e que portanto não representava nenhum risco à minha saúde. Mesmo assim, antes da cirurgia, o médico conversou comigo para me acalmar e explicou muito atenciosamente como que a operação prosseguiria, fazendo com que eu me sentisse muito mais segura." (Aluna, 18 anos)

"Vivo uma experiência de humanização toda vez que vou à minha médica ginecologista: ela me recebe na porta, explica todos os procedimentos, tira todas as minhas dúvidas com comunicação clara. Usa o tempo que for necessário pra isso." (Aluna, 23 anos)

"Na última consulta em que estive presente, o médico que me atendeu tratou-me com tamanho interesse e delicadeza que fiquei surpresa. Foi uma verdadeira experiência de humanização, uma vez que o profissional de saúde tratou-me pelo nome, perguntou a minha história e pareceu de fato se preocupar com meu problema de saúde. Saí da consulta incrivelmente satisfeita." (Aluna, 18 anos)

"O maior exemplo de humanização veio do meu pediatra, que acompanhou todo meu crescimento ao longo da minha juventude. Sempre me explicando todos os procedimentos sendo feitos, de uma forma simples e calma para que eu pudesse entender; sempre contextualizando com histórias as medidas a serem tomadas, como vacinas, exames e até dietas e exercícios físicos, para abaixar meu sobrepeso. O punho firme e o olho no olho em todas as consultas, sempre me davam confiança e inspiravam legitimidade no bom atendimento do doutor Zé.” (Aluno, 19 anos)

"Em um dia escolar, enquanto praticava um esporte, eu acabei fraturando um osso do pulso. Já na escola, os monitores me ajudaram, perguntando de modo atencioso o que acontecera e tentando aliviar a dor (ainda que com cuidados básicos, pois não sabiam que realmente havia fraturado). Na consulta, o médico que me atendeu conversou comigo e com minha mãe, comunicando a fratura (após o raio-x) e me acalmando, afirmando que 'não era nada', que dali a pouco melhoraria, mas que precisaria engessar (ele 'brinca' com relação ao gesso falando que todos meus colegas da escola 
escreveriam no gesso, o que me divertiu um pouco, apesar da situação). Na escola, no dia seguinte, todos me acolheram, mostrando preocupação e disposição para me ajudar em tudo o que eu precisasse, o que realmente aconteceu. Todos esses pequenos momentos demonstraram humanização no cuidado que comigo tiveram." (Aluno, 17 anos)

"Uma vez ao ir ao pronto-socorro tive que aguardar por mais uma hora até o atendimento. Ao entrar na sala, os ânimos estavam bastante exaltados, mas, no entanto, $o$ atendimento recebido foi de tal qualidade e a atitude do médico tão calma e atenciosa, que todo o problema prévio foi facilmente contornado e superado.” (Aluno, 18 anos)

"Em uma típica consulta rotineira, durante o ano de vestibular, o médico, o qual constantemente eu passava, percebeu o quão estressado/nervoso eu estava, sem eu comentar sequer sobre o assunto, em seguida, ouviu-me e, inclusive, me orientou sobre algo que jamais esperaria ser assunto de uma consulta médica rotineira: vestibular. Obviamente essa experiência foi muito positiva." (Aluno, 18 anos)

"Uma experiência de humanização foi quando um médico me explicou usando até mesmo desenhos, em que consistia a minha enfermidade e como ela poderia ser corrigida cirurgicamente. Eu considero essa atitude uma forma de humanização porque demonstra consideração por parte do médico, além de eu me sentir mais seguro entendendo o que seria feito. Eu tive a impressão de que estava de certo modo mais 'envolvido' com o tratamento." (Aluno, 17 anos)

"A última vez que fui ao oftalmologista fui atendido de uma forma que considerei humanizada. Além de fazer os exames de rotina, o médico teve uma conversa amigável comigo e ao descobrir que eu almejava me tornar médico conversou comigo sobre a profissão e me explicou como algumas cirurgias ocorriam. Além disso, o médico me passou seu contato se prontificando a me ajudar no que fosse necessário. A consulta, além do caráter técnico, foi excelente, pois me incentivou a continuar estudando para me tornar médico." (Aluno, 19 anos)

"No início desse ano, fui em um cardiologista que, para explicar o que possivelmente estava acontecendo comigo, criou uma história envolvendo homens da caverna, e a contou numa linguagem bastante simples. Achei essa atitude muito bacana, pois o médico soube como explicar para mim, paciente, o que eu tinha, sem precisar usar termos técnicos de difícil compreensão." (Aluno, 20 anos)

\section{Nas relações humanas contemporâneas}

"Aula de história, Colégio x, São Paulo. Depois de uma discussão no carro e imersa em inúmeros problemas familiares, cheguei à escola para um dia de aula normal. A primeira aula seria a de história. Eu fui à aula, mas não estava presente de fato. Durante todos os minutos, estava pensando sobre minha casa, minha família, familiares adoecendo, falecendo, e por aí vai... Ao final da aula, o professor me perguntou se eu estava bem. Eu não tinha chorado nem demonstrado algo (pelo que eu sabia). Mas ele percebeu que eu não olhei nos olhos dele durante a aula, e concluiu que tinha algo errado. Nós conversamos, eu expliquei pela primeira vez a alguém o que estava 
acontecendo, e isso mudou o resto do meu dia. Eu pude focar nas outras aulas e seguir em frente. E o meu (querido) professor não teria percebido nada disso se ele não estivesse olhando nos meus olhos, pra ver que eu não estava (realmente) naquela aula. (Aluna, 18 anos)

"Para mim, a maior experiência de humanização era ajudar os colegas no ensino médio. Possuindo facilidade em diversas matérias, sempre estive disposto a ajudar colegas, independente da dificuldade que tinham, ou do tempo que levaria. Era extremamente gratificante ouvir 'você me salvou' após uma prova ou até mesmo em um vestibular. É essa sensação que quero ter como médico." (Aluno, 18 anos)

"Para mim, o 'simples' ato de construir um vínculo com alguém é uma experiência de humanização. Receber a atenção, o suporte e o carinho dos pais é ser humanizado. Fazer novas amizades e manter amizades antigas, ou seja, estabelecer relação de carinho, afeto e confiança com alguém antes totalmente estranho a você, conhecer o outro e se apresentar ao outro, é uma experiência de humanização. Nesse mesmo sentido, ser tratado com respeito e cordialidade por qualquer pessoa (uma pessoa no metrô, um vendedor, um segurança, um professor...) é uma forma de humanização." (Aluno, 20 anos) 


\begin{abstract}
ANEXo E
Conjunto completo de discursos referentes à Pergunta 4 - Quando você pensa em humanização na prática médica, qual a imagem ou modelo vêm à mente? Comente histórias que você leu, ouviu, assistiu nos diferentes meios impressos, virtuais, sonoros (música), visuais (filmes, peças de teatro, séries, documentários).
\end{abstract}

\title{
Imagens
}

\section{Filmes}

“Um filme chamado 'Intocáveis' retrata bem isso, e fala sobre tratar dos doentes sem ter pena, mas considerando que são pessoas com histórias de vida antes da doença." (Aluna, 21 anos)

"No filme Patch Adams, o modelo que o protagonista apresenta de humanização é incrível, o jeito como ele tenta mostrar a todos que há felicidades na vida e como cada paciente é único e deve ser tratado com singularidade me faz pensar que é assim que um médico deve ser." (Aluna, 22 anos)

"A principal imagem de humanização que me lembro é do médico do filme 'Patch Adams' que entrava no hospital com o objetivo de alegrar os pacientes e garantir a eles uma qualidade de vida melhor." (Aluna, 20 anos)

"O filme 'O Renascimento do Parto' mostra a humanização e o respeito ao nascimento, desde a gestação até os cuidados com o recém-nascido." (Aluna, 21 anos)

"Obras como "Patch Adams" e "Mente Assombrada" me vem à mente como exemplos dos impactos do atendimento médico humanizado." (Aluna, 26 anos)

"O modelo de humanização para mim, é o cuidador do paciente tetraplégico no filme 'Intocáveis', pois ele não se limita às funções de dar banho e comida ao paciente, mas se mostra amigo, altruísta e dedicado, se importando com aspectos além da condição física de saúde do homem." (Aluna, 20 anos)

"O filme que mostra isso[humanização] é o que conta a história de Patch Adams. Uma cena marcante mostra todos os médicos fazendo perguntas para um paciente sobre seus sintomas e falando com um linguajar técnico, enquanto Patch apenas pergunta seu nome, fazendo o paciente se sentir mais confortável. Patch também levava brinquedos para as crianças e se vestia de palhaço, fazendo-as felizes e contribuindo para seu bemestar." (Aluna, 18 anos)

"A questão de um médico humanizado pode ser encontrada na figura de Dr. Adams vivido no cinema por Robin Williams. A questão do médico como personagem lúdica ou graciosa reitera a proposição de que a prática da medicina humanizada reside principalmente na ocupação, por parte do profissional, de uma miríade de papéis que 
possam fornecer conforto e refrigério ao paciente dentro de determinado contexto." (Aluna, 17 anos)

"A imagem que tenho de um 'médico humanizado', curiosamente, vem de alguém não médico. No filme 'Óleo de Lorenzo', o menino protagonista, deficiente, sobre com o abandono de inúmeros médicos diante de suas dificuldades. Encontra acalanto na persistência do pai, que estuda a deficiência do filho, dele cuida e a ele busca prover boas condições de vida. Para mim, um médico deve encarar, em seu paciente, um filho, a quem ensina, de quem cuida, e, também, com quem aprende e aprende histórias." (Aluna, 18 anos)

"Alguns filmes e séries apresentam tais tipos de profissionais, como no filme Patch Adams, em que este é um médico que faz de tudo para tornar a vida dos seus pacientes mais feliz e amenizar o seu sofrimento." (Aluna, 18 anos)

"Filmes: Patch Adams - busca por alívio psicológico e realização dos pacientes. Gênio indomável - psicólogo compreende que apenas se considerar a cultura conseguirá ser efetivo." (Aluna, 30 anos)

"Um filme que me remete a humanização é o qual trata a história do Patch Adams que dava atenção necessária a seus pacientes.” (Aluna, 19 anos)

"A humanização na prática médica sempre me lembra do filme Patch Adams que trata justamente da busca por conexão com o paciente e da intervenção psicológica na busca por um melhor estado mental do paciente. Esse filme como um todo, apesar de exagerado em alguns aspectos, traduz bem o conceito de humanização e o faz de uma forma prática e lúdica." (Aluna, 22 anos)

"Ao pensar em humanização na prática médica, me vem à mente a imagem de um profissional capaz de estabelecer uma relação pessoal de confiança com o paciente, sendo que os principais exemplos que consigo pensar agora são o médico do filme Tempo de Despertar e o médico Patch Adams)." (Aluno, 18 anos)

"A medicina deve zelar pelo paciente como um todo, inclusive de seus medos, anseios, preocupações. Devemos confortar o paciente e não somente agirmos como máquinas de fazer diagnóstico. Enfim [...], creio que o filme 'Patch Adams - O amor é contagioso', com Robin Williams, faz isso muito bem.” (Aluno, 21 anos)

"Quando penso em humanização na prática médica, certamente me vem à mente o filme Patch Adams. Após uma tentativa de suicídio, Adams se interna em um manicômio com o objetivo de ajudar os outros e ali descobre sua vocação médico-humanitária, o que realça que colocar-se no lugar do paciente - ou já ter realmente estado lá - facilita a compreensão da importância do cuidado e da humanização na prática médica." (Aluno, 20 anos)

'No filme 'Intocáveis', essa figura (paternal, acolhedora e reconfortante) é retratada por um homem que trabalha como cuidador de um milionário tetraplégico, e é capaz de criar um vínculo de extremo carinho apesar das dificuldades inicialmente encontradas." (Aluno, 20 anos) 
"Um ótimo exemplo de humanização médica é visto no filme Patch Adams, em que um dos fatores apontados como mais eficientes no tratamento é a alegria." (Aluno, 21 anos)

"Uma história, relacionada à humanização, que me vem frequentemente à mente é a do neurocirurgião Ben Carson, cuja biografia foi retratada no filme 'Gifted Hands'. O filme mostra que Carson, antes de toda cirurgia que fazia, reunia paciente e família do paciente para realizar uma oração pedindo que Deus guiasse o procedimento cirúrgico. Mesmo que o paciente não fosse religioso, esse contato próximo entre médico e paciente confortava o paciente e sua família, tornando-os mais confiantes de que o procedimento ocorreria como o esperado." (Aluno, 18 anos)

"Humanização é fazer surgir o bem em meio à frieza e crueldade que há na sociedade. Essa ideia está contida no filme A vida é bela." (Aluno, 19 anos)

"Penso num médico que se dedique à resolução ou melhoria do estado de saúde de seu paciente. Num médico atencioso, solícito, dedicado. Acho que essa dedicação é visível num filme sobre Ben Carson [Mãos Talentosas].” (Aluno, 20 anos)

"Quando penso em humanização, a primeira imagem que me vem à mente é uma cena do filme 'Patch Adams - o amor é contagioso', em que o personagem principal interpretado por Robin Williams, é um médico destinado a colocar alegria no coração de seus pacientes e, assim, ele aparece confortando uma criança com câncer, enquanto ela aperta o grande nariz vermelho de palhaço que ele utiliza." (Aluno, 20 anos)

"A primeira imagem de Humanização que me vem à mente pertence ao filme 'Patch Adams', que mostra que o cuidado com o paciente vai muito além de saber o número de seu leito, porém também o seu nome." (Aluno, 19 anos)

"Na infância, fui influenciado pelo filme Patch Adams, posteriormente, recebendo influência na maturidade do filme Gênio Indomável e da série House (exemplo de desumanização)." (Aluno, 21 anos)

“O filme 'Sete Vidas' me lembra o que compreendo por humanização. Independentemente de seus motivos, o personagem principal se coloca no lugar de outros sete seres humanos e faz de tudo para ajudá-los em suas batalhas diárias, se ajustando ao contexto de cada indivíduo de cuja vida ele pretende melhorar." (Aluno, 20 anos)

"Quando penso em humanização da prática médica a imagem que vem à mente é do médico Patch Adams. Nessa história, o médico, além de cuidar e tratar da doença que acomete o paciente, preocupa-se em tratar, também, do emocional; busca ouvir a história da pessoa, entender seus sentimentos e suas angústias.” (Aluno, 22 anos)

"A respeito de humanização na prática médica, um modelo expressivo que vem à minha mente é o idealizado por Patch Adams. Seja no filme, seja nas palestras dadas por ele, a proposta transmitida de priorizar o bem-estar em detrimento até mesmo de impedir o óbito é ideal. Isso porque muitas vezes a busca pela cura pode desumanizar o cuidado, pois ela pode sacrificar o bem-estar do paciente." (Aluno, 23 anos) 


\section{Livros}

“... li um livro chamado 'Presas que menstruam', que, falando da condição das mulheres presas no Brasil, mencionava que presas que davam à luz, muitas vezes, fizeram o parto algemadas. Essa situação, para mim, seria inadmissível por um médico humano, que de fato leva em conta a dor daquela mulher, a importância daquele momento e que aquela paciente, como qualquer outra, merece tratamento digno." (Aluna, 18 anos)

"Considerando humanização como oposto de coisificação me lembrei de um livro chamado 'Garoto extraordinário', no qual Auggi [August Pullman], um garoto de cerca de dez anos finalmente vai à escola, mas encontra a dificuldade de ser aceito devido ao seu rosto desfigurado. Contudo, depois de muita coragem ele consegue ser reconhecido como uma criança normal que não quer ficar só." (Aluna, 19 anos)

“O livro 'Maternagem' fala sobre humanização na criação dos filhos e o profissional de pediatria aliando-se à família para o melhor cuidado com a criança.” (Aluna, 21 anos)

"Livro: Humano, Demasiado Humano, de Friedrich Nietzsche em que o autor em parte do livro comenta que a profissão médica é um exemplo de humanização. Na qual, o médico deve ser para o paciente uma forma de amparo, não só fisicamente mas também emocionalmente." (Aluna, 19 anos)

"Obras como 'Patch Adams' e 'Mente Assombrada' me vem à mente como exemplos dos impactos do atendimento médico humanizado." (Aluna, 26 anos)

"Livros que me vêm à mente: Fausto, de Goethe, A morte de Ivan Ilitch, de Tolstói. Não são necessariamente livros com personagens exemplo, mas que contribuem para reflexão sobre humanização na medicina ou para se refletir sobre o que é sucesso/felicidade profissional." (Aluno, 19 anos)

"Imagino o médico que compreende o paciente; e o paciente que compreende o médico. Conto 'Amor', de Clarice Lispector.” (Aluno, 19 anos)

“... o livro 'Estação Carandiru' de Drauzio Varella trata de um processo de conhecimento do universo do sistema carcerário. Do livro, é possível perceber uma densidade psicológica de vários dos indivíduos inclusive a presença de um código de conduta dentre os presos. Assim, o autor estimula a humanização na prática médica, pois, até num ambiente marginalizado, há uma alma por trás de cada pessoa." (Aluno, 21 anos)

\section{Seriados}

“Não assisti, mas já ouvi falar de um episódio de 'Dr. House' em que faltavam apenas alguns minutos para que o paciente viesse a óbito e este perguntou ao doutor House o que fazer e ele respondeu algo como: 'nesse tempo, só podemos fazer um miojo'. Bem, para mim, essa falta de empatia denota um certo descaso com o paciente e é o modelo 
oposto - na minha visão - ao profissional da saúde que visa à humanização.” (Aluna, 19 anos)

"Penso em profissionais preocupados com seus pacientes como se os mesmos fossem entes próximos e importantes. Penso, por exemplo, nos médicos do Grey’s Anatomy." (Aluna, 18 anos)

"Na série de televisão 'Grey's Anatomy', a pediatra Arizona Robbins trata de um menino com câncer durante um tempo e durante a noite o menino sempre pede para que os pais ou alguma enfermeira o benzam 3 vezes seguidas para que ele tenha bons sonhos. A própria médica faz isso quando ele está em isolamento e não pode ver os pais e quando o menino sofre complicações e morre, ela se junta aos pais para abençoá-lo uma última vez. Isso mostra o seu lado humano e sua consideração pela criança e pela família, sendo um exemplo de humanização que pretendo levar para minha carreira médica." (Aluna, 20 anos)

“Na série 'House' há em muitos episódios momentos em que o personagem principal age de forma rude com o paciente. Isso contraria a Humanização. Todavia, o melhor amigo de House, Dr. Wilson, é um exemplo de médico humanista, que sempre trata e cuida dos seus pacientes com atenção, paciência e tolerância." (Aluna, 18 anos)

“Assisto à série 'Gray's Anatomy' e nela já vi vários casos de humanização, nos quais os médicos aproximam-se dos pacientes fornecendo-lhes conforto, ajuda e um tratamento mais eficiente possível. Em vários desses casos, me senti inspirada e ainda mais ansiosa para adentrar no mundo da medicina." (Aluna, 19 anos)

“Também na sérire 'House', a Dra. Cameron seria um exemplo de médica que se importa e tem empatia com os doentes." (Aluna, 18 anos)

"O antagônico de uma prática médica humanizada seria o personagem 'Dr. House', da série 'House'." (Aluno, 21 anos)

“A série Grey's Anatomy mostra em várias cenas a experiência de humanização, como quando os médicos se envolvem com o paciente e lutam pelo seu bem-estar e pela sua felicidade." (Aluno, 17 anos)

"Um médico humano deve ser o oposto do célebre Dr. House.” (Aluno, 21 anos)

"Um exemplo de total falta de humanização é a relação estabelecida com os pacientes pelo médico protagonista da série Dr. House.” (M18)

"Na infância, fui influenciado pelo filme Patch Adams, posteriormente, recebendo influência na maturidade do filme Gênio Indomável e da série House (exemplo de desumanização).” (Aluno, 21 anos) 
“No documentário 'O Renascimento do Parto', além de problematizar a questão do parto, mostra uma maneira humanizada de dar à luz a uma nova vida, seja em casa, no hospital, parto normal ou cesariano de maneira a tornar esse momento especial para a mãe, ao invés de traumatizante como é comum ocorrer." (Aluna, 22 anos)

"Quando eu penso em humanização na prática médica me recordo do documentário 'Chernobyl Heart', o qual mostrou o atendimento médico em uma região da Bielorrússia. Nesse atendimento, os profissionais da saúde se colocaram tratando-os de forma acolhedora e empática. Além disso, questionaram-lhes sobre seus sonhos e sobre características de suas rotinas, dando voz àquelas pessoas que já haviam sofrido tanto." (Aluno, 20 anos)

\section{Iniciativas}

Arte, alegria e saúde

"Quando penso em humanização, duas extensões da faculdade me vêm à mente: o EMA e o MadAlegria. O EMA me foi apresentado por vários alunos da faculdade, que dizem ser muito gratificante porque os pacientes ficam muito felizes de ter alguém para atendê-los. O MadAlegria eu tinha uma noção porque já conhecia o projeto dos Doutores da Alegria." (Aluna, 17 anos)

"Quando penso em humanização me vem à mente a imagem dos doutores da alegria e dos diversos projetos realizados na área hospitalar que buscam o bem-estar da população." (Aluna, 19 anos)

"Uma das práticas médicas que me vêm à mente, relacionada com a humanização são os Hospitalhaços. Nessa prática vejo que o paciente não é tratado apenas como mais um no hospital, assim, o projeto cuida do social e do mental do paciente no processo de humanização." (Aluna, 20 anos)

"Tomo como modelo de humanização o Projeto Doutores da Alegria e a ação do doutor Patch Adams [...]. Embora a humanização não necessite de um tom cômico, a atenção é a minha referência de atendimento humanizado." (Aluno, 18 anos)

"Ao pensar em humanização penso imediatamente nos 'médicos da alegria', como os da extensão MadAlegria da FMUSP." (Aluno, 20 anos)

"Como exemplos de projetos de humanização, já li sobre o MadAlegria, um grupo de palhaços que visita hospitais, realizando atividades de recreação com os pacientes." (Aluno, 22 anos) 


\section{Medicina sem fronteiras Práticas sem Fronteiras}

"O primeiro modelo que me vem à mente é a ONG Médicos Sem Fronteiras, pois admiro muito seu trabalho. Esses médicos partem para as regiões mais carentes, muitas vezes locais em guerras que apresentam perigo, com o único objetivo de ajudar os outros. Assim, eles percebem a dimensão social e a necessidade dessas pessoas e fazem o possível para melhorar as condições delas.” (Aluna, 19 anos)

"Iniciativa: Fundação Make a Wish: tenta realizar sonhos de pacientes - especialmente crianças - com doenças graves / terminais." (Aluna, 30 anos)

"Eu penso nos projetos sociais de médicos que atendem populações ribeirinhas no Norte do Brasil, atendendo famílias inteiras. Esses médicos vão até lá para cuidar de pessoas sem outros interesses ou tarefas e isso lhes permite atender de forma dedica, sem pressa, entendendo um pouco sobre seus pacientes e suas vidas." (Aluno, 23 anos)

"A humanização na prática médica traz uma imagem de um médico que dialoga com seus pacientes e não trata somente das patologias, está disposto a ouvir histórias e a aconselhar. Vê-se tal prática, por exemplo, em uma série de documentários que tratam da área da saúde em territórios afastados dos grandes centros urbanos, como a região Amazônica, ou em áreas de conflito, médicos sem fronteiras no Oriente Médio e África por exemplo." (Aluno, 19 anos)

"Quando eu penso em humanização na prática médica, vem-me à mente a imagem de trabalhos médicos voluntários de campo; como os realizados pelas instituições Cruz Vermelha, Médico sem Fronteiras, ONU..." (Aluno, 19 anos)

"A humanização na prática médica, na minha opinião, está relacionada à imagem de um profissional que vai além de seus próprios interesses no exercer da profissão, como o programa Cruz Vermelha, em que os profissionais vão às áreas mais remotas na tentativa de melhorar as condições de vida da população local.” (Aluno, 20 anos)

"A história que mais me impressionou foi o trabalho realizado pelo Núcleo de Humanização do Hospital das Clínicas, um departamento exemplar na sua área de atuação. Esse núcleo trabalha a ambiência do leito infantil, dando vida ao local e mantendo aberta uma brinquedoteca aos pacientes; além disso, disponibiliza vídeos de desenhos durante exames para acalmar as crianças e fazê-las mais confortáveis no ambiente hospitalar." (Aluno, 17 anos)

"Quando penso na prática médica humanizada, vem à mente os médicos que vão até a África, cuidar das pessoas de regiões miseráveis, colocando em risco a própria vida, para ajudar o próximo, independente onde seja." (Aluno, 20 anos)

\section{Modelos}

\section{Médicos / área da saúde}

"Sempre vi minha mãe, que é enfermeira, atender os pacientes dela dessa forma, e esse foi o meu maior exemplo." (Aluna, 21 anos) 
"Quando penso em um modelo de humanização na prática médica, lembro do endocrinologista que cuida de mim e da minha família, cujas consultas são feitas de maneira atenciosa e paciente, ele procura sempre facilitar os tratamentos de acordo com a realidade de cada paciente." (Aluna, 22 anos)

"Meu principal modelo de humanização é meu médico homeopata. Em todas as minhas consultas ele me dá a sua mão e senta ao meu lado para me ouvir. Ele escuta não apenas as minhas queixas clínicas, mas minhas conquistas, minhas alegrias e minhas frustrações." (Aluna, 20 anos)

"Quando penso em humanização me vem à mente o doutor Drauzio Varella, que tem vários livros sobre a experiência dele na área médica e cita casos que o marcaram. Para mim os relatos dele são realmente impactantes pois mostram como o cuidado com o paciente faz a diferença e como a profissão médica vai além do simples conhecimento técnico, exigindo muito do emocional do médico." (Aluna, 25 anos)

"Me vem à mente ... imagens de profissionais como meu ortopedista, que me acompanha há muito tempo por um problema simples genético que tenho. Ele sempre comenta como gosta do que faz, como seus pacientes são interessantes e tudo mais." (Aluna, 18 anos)

"Me vem à mente a imagem de uma médica que acompanhei em um trabalho voluntário no interior de São Paulo em um quilombo. Era uma pediatra cujas consultas eram realizadas de modo tão carinhoso e atencioso com todos os envolvidos (pais, pacientes, irmãos e até mesmo alunos que assistiam e queriam participar) que me deixaram encantada e ansiosa com a profissão médica." (Aluna, 19 anos)

"Apesar de ter ambos os pais médicos, sempre tive como modelo o meu pai. Em inúmeros jantares ele me contava sobre casos clínicos e em como muitos deles, a causa do problema nem sempre é físico. Casos de ansiedade, de depressão e medo, e o modo que ele relatava lidar com isso, através de conversa e amizade, sempre me serviu de exemplo de humanização e bom profissional.” (Aluno, 18 anos)

"Quando penso em humanização na prática médica a imagem que me vem na cabeça é a maneira como meu tio me tratou quando precisei costurar um ferimento no queixo. A maneira com a qual foi feito o exercício da prática médica foi realmente acolhedora e ficou nítido que era assim que ele tratava todos os pacientes." (Aluno, 18 anos)

"O neurocirurgião Ben Carson, em seu filme que conta a sua história, age de maneira extremamente humana com os seus pacientes, com destaque para o carinho e a preocupação que ele tem com a família de seus pacientes." (Aluno, 19 anos)

"Lembro-me de minha mãe [médica] contando sobre uma paciente que teve várias dificuldades pessoais e acabou se apegando pela minha mãe, por seu contato humanizado." (Aluno, 17 anos)

"Vêm à mente a imagem de três médicos, extremamente competentes tecnicamente mas também igualmente humanos em seus atendimentos. Primeiramente meu pediatra, que sempre me fez sentir calma e confiante nas consultas, havendo medidas a serem tomadas ou não. Também me recordo do meu pai, que sabe escutar e dialogar com o 
paciente, doente ou não, criança ou idoso, caso grave ou não, sempre tratando a todos igualmente, sem distinções ou privilégios, inspirando assim muito carinho e dedicação ao cuidado do próximo. Por fim me recordo do meu tio, cirurgião plástico, que quando recebe um ou uma paciente com vaidades estéticas desnecessárias, busca mostrar a eles que são pessoas belas do jeito que são, não meramente as opera pensando no dinheiro. Além disso, atualmente ele mora no Acre, onde ocorrem muitos casos de tumores nas populações indígenas, trabalhando em cirurgias plásticas de reconstrução, um projeto que admiro imensamente." (Aluno, 19 anos)

"Um modelo que vem à minha mente ao pensar em humanização na prática médica é o de Drauzio Varella no livro Estação Carandiru, pois ele tratava de criminosos como seres humanos, apesar dos crimes que eles cometeram." (Aluno, 26 anos)

"Ao pensar em humanização na prática médica o grande modelo que me ocorre é o meu pai. Não por um 'corporativismo familiar', mas pelos exemplos de ética e respeito, aliados à valorização da vida humana, praticados não só na profissão, como também fora dela e com os quais pude aprender." (Aluno, 19 anos)

"O médico oncologista da minha avó. No seu tratamento, muitos médicos não possuíam o toque, o espírito como o dele. Sua melhora só foi constatada quando finalmente o encontramos. Sua humanização com certeza afetou no tratamento..." (Aluno, 19 anos)

\section{Religiosos}

"Como imagem e modelo, lembro-me da história do bom samaritano, que acolhe e ajuda uma pessoa de uma tribo rival.” (Aluno, 38 anos)

"A minha religião define muito do que sou. O meu modelo, quando penso em humanização, é Jesus Cristo e seus ensinamentos. A história mais representativa é a da adúltera levada a julgamento quando pega em flagrante. Jesus não hesitou em pensar na mulher como o que ela é e não pelos erros que cometeu." (Aluno, 19 anos)

"Jesus. Relacionamento interpessoal sem julgamentos prévios. Alto conhecimento intrapessoal. Habilidade de comunicar-se de forma carinhosa, afetiva e eficaz. Toque. Todas essas características levam-me a crer que Jesus Cristo, como retratado em uma miríade de momentos bíblicos relacionados a fenômenos de cura, é um exemplo de humanização." (Aluno, 17 anos) 


\section{REFERÊNCIAS}

Abbagnano N. Dicionário de Filosofia. 5ª Ed. São Paulo: Martins Fontes; 2007.

Adler MJ. A proposta paideia. Brasília: Editora Universidade de Brasília, 1984.

Arntfield S, Slesar K, Dickson J, Charon R. Narrative medicine as a means of training medical students toward residency competencies. Patient Education and Counseling 91 (2013) 280-286.

Ayres JRCM. O cuidado, os modos de ser (do) humano e as práticas de saúde. Saúde e Sociedade v. 13, n. 3, p.16-29, set-dez 2004.

. Hermenêutica e humanização das práticas de saúde. Ciência \& Saúde Coletiva, 10(3):549-560, 2005.

. Uma concepção hermenêutica de saúde. PHYSIS: Ver. Saúde Coletiva, Rio de Janeiro, 17(1):43-62, 2007.

Organização das Ações de Atenção à Saúde: modelos e práticas. Saúde $e$ Sociedade, v. 18, supl. 2, 2009.

Ayres, JRCM, Rios IC, Schraiber LB, Falcão MTC; Mota A. Humanidades como Disciplina da Graduação em Medicina. Revista Brasileira de Educação Médica 37(3): $455-463 ; 2013$.

Bardin L. Análise de Conteúdo. São Paulo: Edições 70; 2011.

Bauman Z. Ensaios sobre o conceito de cultura. Rio de Janeiro: Zahar; 2012. Sobre educação e juventude. Rio de Janeiro: Zahar; 2013.

Benedict R. Padrões de Cultura. Petrópolis, RJ: Vozes; 2013.

Benevides R, Passos E. A humanização como dimensão pública das políticas de saúde. Ciência \& Saúde Coletiva, 10(3):561-571, 2005.

Benjamin W. Magia e técnica, arte e política: ensaios sobre literatura e história da cultura. São Paulo: Brasiliense; 2012. 
Berman M. Tudo que é sólido desmancha no ar: a aventura da modernidade. São Paulo: Companhia das Letras; 2007.

Bernard AW, Malone M, Kman NE, Caterino JM, Khandelwal S. Medical Student Professionalism Narratives: A Thematic Analys and Interdisciplinary Comparative Investigation.. BMC Emergency Medicine 2011 11:11.

Bittar Y, Sousa MAS, Gallian DMC. A experiência estética da literatura como meio de humanização em saúde: o Laboratório de Humanidades da Escola Paulista de Medicina, Universidade Federal de São Paulo. Interface Comunicação Saúde Educação, v.17, n.44, p.171-86, jan./mar. 2013.

Brasil. Ministério da Educação. Diretrizes Curriculares - Cursos de Graduação, 2014. (Disponível em: http://portal.mec.gov.br/index.php?option=com_docman\&view=download\&alias=1532 7-pces025-14\&category_slug=janeiro-2014-pdf\&Itemid=30192. Acesso em 08 set. 2017)

Brasil. Ministério Da Saúde. Programa Nacional de Humanização da Assistência Hospitalar. Brasília-DF, 2001.

HumanizaSUS: Política Nacional de Humanização. Brasília-DF, 2004.

Brockmeier J, Harré R. Narrativa: Problemas e Promessas de um Paradigma Alternativo. Psicologia: Reflexão e Crítica, 2003, 16(3), pp. 525-535.

Canmeds. Disponível em http://www.royalcollege.ca/rcsite/canmeds/about-canmeds-e. Acessado em 21/05/2016.

Caprara A, Franco ALS. Relação Médico-Paciente e Humanização dos Cuidados em Saúde: limites, possibilidades, falácias. In: Deslandes SF (Org.). Humanização dos Cuidados em Saúde: conceitos, dilemas e práticas. Rio de Janeiro: Editora FIOCRUZ; 2006.

Carrascoza JA. Caderno de um ausente. São Paulo: Cosac Naify; 2014. 
Charon R. Our Heads Touch: Telling and Listening to Stories of Self. Acad Med. 2012 [A] September; 87(9): 1154-1156.

At the Membranes of Care: Stories in Narrative Medicine. Acad Med. 2012 [B] March; 87(3): 342-347. 2012A.

Narrative Medicine: honoring the stories of illness. New York: Oxford University Press; 2006.

. Narrative Medicine: Attention, Representation, Affiliation. Narrative. Vol. 13. No. 3, Oct., 2005.

Narrative Medicine: A Model for Empathy, Reflection, Profession, and Trust. JAMA, October 17, 2001 - Vol 286, No. 15.

Dasgupta S, Charon R. Personal Illness Narratives: Using Reflective Writing to Teach Empathy. Academic Medicine, Vol. 79, 4/April 2004.

De Benedetto MA, Blasco P, Gallian DMC. Narrativas de estudantes de Medicina e Enfermagem: o que elas nos revelam? Disponível em: http://www.moreirajr.com.br/revistas.asp?fase=r003\&id_materia=5532. Acessado em 10.abril.2016.

Deslandes SF. Humanização: revisitando o conceito a partir das contribuições da sociologia médica. In: Deslandes SF (Org.). Humanização dos Cuidados em Saúde: conceitos, dilemas e práticas. Rio de Janeiro: Editora FIOCRUZ; 2006.

Análise do discurso oficial sobre a humanização da assistência hospitalar. Ciência \& Saúde Coletiva, 9(1):7-14, 2004.

Dyrbye L, Harris I, Rohren C. Early Clinical Experiences from Students' Perspectives: A Qualitative Study of Narratives. Academic Medicine, Vol. 82, No. 10 / October 2007.

Favoreto CA, Cabral CC. Narrativas sobre o processo saúde-doença: experiências em grupos operativos de educação em saúde. Interface Comunicação Saúde Educação v.13, n.28, p.7-18, jan./mar. 2009. 
Favoreto CA, Camargo Jr. Narrative as a tool for the development of clinical practice. Interface-Comunic., Saude, Educ., v.15, n.37, p.473-83, abr./jun. 2011.

Fernandes CH. "A educação clássica é a opressão da ignorância." In: Giuliano T. Desconstruindo Paulo Freire. Porto Alegre: História Expressa: 2017, p. 57-71.

Gadamer H-G. O caráter oculto da saúde. Petrópolis: Vozes; 2011. Verdade e Método. Petrópolis: Vozes, 2003.

Gallian DMC, Pondé LF, Ruiz R. Humanização, Humanismos e Humanidades: problematizando conceitos e práticas no contexto da saúde no Brasil. Revista Internacional de Humanidades Médicas Volume 1, Número 1, 2012.

Garrison D, Lyness J, Frank J, Epstein R. Qualitative Analysis of Medical Student Impressions of a Narrative Exercise in the Third-Year Psychiatry Clerkship. Academic Medicine, Vol. 86, No. 1 / January 2011.

Greenhalgh T, Russell J, Swinglehurst D. Narrative methods in quality improvement research. Disponível em http://www.ncbi.nlm.nih.gov/pmc/articles/PMC1744090/pdf/v014p00443.pdf. Acessado em 10.abril.2016.

Henry P, Moscovici S. Problèmes de l'analyse de contenu. In: Langages, 3e année, no. 11, 1968. Sociolinguistique. pp. 36-60.

Hurwitz B. Narrative and the practice of medicine. The Lancet Vol 356 December 16, 2000.

Karnieli-Miller O, Vu R, Holtman M, Clyman S, Inui T. Medical Students Professionalism Narratives: A Window on the Informal and Hidden Curriculum. Academic Medicine, Vol. 85, No. 1 / January 2010.

Kilminster S, Downes J, Gough B, Murdoch-Eaton D, Roberts T. Women in medicine s there a problem? A literature review ot the changing gender composition, structures and occupational cultural in medicine. Medical Education 2007; 41: 39-49. 
Kloster MC, Perotta B, Hauer Junior A, Paro HBMS, Tempski P. Sonolência Diurna e Habilidades Sociais em Estudantes de Medicina. Revista Brasileira de Educação Médica. 37(1) : 103-109; 2013.

Kumagai AK. From Competencies to Human Interests: Ways of Knowing and Understanding in Medical Education. Academic Medicine, Vo. 89, No. 7 / July 2014.

A Conceptual Framework for the Use of Illness Narratives in Medical Education. Academic Medicine, Vol. 83, No. 7 / July 2008.

Kumagai A, Lypson M. Beyond Cultural Competence: Critical Consciousness, Social Justice, and Multicultural Education. Academic Medicine, Vol. 84, No. 6 / June 2009.

Kumagai A, White CB, Perlman RL, Fantone JC. The interpretive project: a creative educational approach to fostering medical students' reflections and advancing humanistic medicine. Reflective Practice Vol. 11, No. 4, September 2010, 517-527.

Les Todres, Galvin KT, Holloway I. The humanization of healthcare: A value framework for qualitative research. International Journal of Qualitative Studies on Health and Well-being. 2009; 4: 68-77.

Lévi-Strauss C. A antropologia diante dos problemas do mundo moderno. São Paulo: Companhia das Letras; 2012.

Levine R, Kern D, Wright S. The impact of prompted narrative writing during internship on reflective practice: a qualitative study. Adv in Health Sci Educ (2008) 13:723-733.

Lima CC, Guzman SM, De Benedetto MAC, Gallian DMC. Humanidades e humanização em saúde: a literatura como elemento humanizador para graduandos da área da saúde. Interface Comunicação Saúde Educação 2014; 18(48):139-50.

Mãe VH. O paraíso são os outros. Ilustrações: Nuno Cais. São Paulo: Cosac Naify; 2014. 
Marcum JA. The Role of Empathy and Wisdom in Medical Practice and Pedagogy: Confronting the Hidden Curriculum. Journal of Biomedical Education. Volume 2013, Article ID 923810, 8 pages.

McKinstry B. Are there too many female medical graduates? BMJ 5 april 2008 Volume 336.

Medeiros N, Santos T, Trindade E, Almeida K. Avaliação do Desenvolvimento de Competências Afetivas e Empáticas do Futuro Médico. Revista Brasileira de Educação Médica 37(4):515-525; 2013.

Minayo MCS. A Produção de Conhecimentos na Interface entre as Ciências Sociais e Humanas e a Saúde Coletiva. Saúde Soc. São Paulo, v22, n.1, p.21-31, 2013.

Monrouxe L, Rees C, Endacott R, Ternan E. 'Even now it makes me angry': health care students' professionalism dilemma narratives. Medical Education 2014; 48: 502-517.

Morin E. A via para o futuro da humanidade. Rio de Janeiro: Bertrand Brasil; 2013.

Os sete saberes necessários à educação do futuro. São Paulo: Cortez; Brasília, DF: UNESCO; 2011.

Introdução ao pensamento complexo. Porto Alegre: Sulina; 2011 A.

A cabeça bem-feita: repensar a reformar, reformar o pensamento. Rio de Janeiro: Bertrand Brasil; 2010.

Morin E, Kern AB. Terra-Pátria. Porto Alegre: Sulina; 2011.

Pessotti I. A Formação Humanística do Médico. Simpósio: Ensino Médico de Graduação. Capítulo X. Medicina, Ribeirão Preto, 29: 440-448, out./dez. 1996.

Puvanendran R, Vasanwala F, Kamei R, Hock L, Lie D. What do medical students learn when follow patients from hospital to community? A longitudinal qualitative study. Med Educ Online 2012, 17: 18899.

Rees C, Monrouxe L, Mcdonald L. Narrative, emotion and action: analyzing 'most memorable' professionalism dilemmas. Medical Education 2013; 47: 80-96. 
Reginato V, De Benedetto MAC, Blasco PG, Gallian DMC. Humanismo: pré-requisito ou aprendizado para ser médico? Disponível em: http://www.sobramfa.com.br/artigos/2014_jan_humanismo_pre_requisito_ou_aprendiza do_para_ser_medico.pdf. Acesso em 30.março.2016.

Rios IC, Lopes Jr A, Kaufman A, Vieira JE, Scanavino M T, Oliveira, RA. A Integração das Disciplinas de Humanidades Médicas na Faculdade de Medicina da USP - Um Caminho para o Ensino. Revista Brasileira de Educação Médica 32(1) : 112-121; 2008 .

Rios IC. Humanidades e medicina: razão e sensibilidade na formação médica. Ciência \& Saúde Coletiva, 15(Supl. 1):1725-1732, 2010.

Humanização: a Essência da Ação Técnica e Ética nas Práticas de Saúde. Revista Brasileira de Educação Médica 33 (2) : 253-261; 2009.

Rios IC, Schraiber LB. Humanização e Humanidades em Medicina: a formação médica na cultura contemporânea. São Paulo: Ed. Unesp; 2012.

Shapiro J, Coulehan J, Wear D, Montello M. Medical Humanities and Their Discontents: Definition, Critiques, and Implications. Academic Medicine, Vol. 84, No. 2 / February 2009.

Shapiro J, Kasman D, Shafer A. Words and Wards: A Model of Reflective Writing and Its Uses in Medical Education. J Med Humanit (2006) 27:231-244.

Squire C. O que é narrativa. Civitas, Porto Alegre, v. 14, n. 2, p. 272-284, maio-ago. 2014.

Teixeira RR. Humanização e Atenção Primária à Saúde. Ciência e Saúde Coletiva, 10(3):585-597, 2005.

Tempski et al. What do medical students think about their quality of life? A qualitative study. BMC Medical Education 2012, 12:106.

Tomorrow's Doctors. Disponível em http://www.gmcuk.org/education/undergraduate/undergrad_outcomes.asp. Acessado em 21/05/2016. 
Urquhart L, Rees C, Ker J. Making sense of feedback experiences: a multi-school study of medical students' narratives. Medical Education 2014; 48: 189-203.

WFME. World Federation of Medical Education Guidelines. Disponível em http://wfme.org/projects/guidance/114-criteria-for-establishment-of-a-new-medicalschool-2016/file, 2016.

Wong A, Tollope-Kumar K. Reflections: an inquiry into medical students' professional identity formation. Medical Education 2014; 48: 489-501. 